\title{
TWO-PHASE ANAEROBIC DIGESTION TO REDUCE THE NOx EMISSION POTENTIAL OF BIOGAS
}

\author{
A Thesis \\ presented to \\ the Faculty of California Polytechnic State University, \\ San Luis Obispo \\ In Partial Fulfillment \\ of the Requirements for the Degree \\ Master of Science in Civil and Environmental Engineering \\ by \\ Nathaniel Manuel Olivas
}

December 2015 
(C) 2015

\section{NATHANIEL MANUEL OLIVAS}

ALL RIGHTS RESERVED 


\section{COMMITTEE MEMBERSHIP}

TITLE:

AUTHOR:

DATE SUBMITTED:

COMMITTEE CHAIR:

COMMITTEE MEMBER:

COMMITTEE MEMBER:

\author{
Two-Phase Anaerobic Digestion to Reduce the \\ NOx Emission Potential of Biogas
}

Nathaniel Manuel Olivas

December 2015
Tryg Lundquist, Ph.D., P.E.

Associate Professor of Environmental Engineering

Yarrow Nelson, Ph.D.

Department Chair of Civil and Environmental

Engineering

Gregory Schwartz, Ph.D.

Assistant Professor of BioResource and

Agricultural Engineering 


\section{ABSTRACT \\ Two-Phase Anaerobic Digestion to Reduce the \\ NOx Emission Potential of Biogas \\ Nathaniel Manuel Olivas}

Anaerobic digestion can be used to decrease the mass of organic wastes to be disposed of while producing useful biogas $\left(\mathrm{CH}_{4}\right.$ and $\left.\mathrm{CO}_{2}\right)$ for heat or power production, but in air basins with strict emissions limits, biogas combustion is difficult to implement due to the high costs of controlling NOx emissions. NOx production can be minimized by blending $\mathrm{H}_{2}$ gas with $\mathrm{CH}_{4}$ at a volume ratio of 15:85 $\mathrm{H}_{2}: \mathrm{CH}_{4}$, which allows burning at ultra-lean air-to-fuel ratios. For biogas systems, a potential low-cost NOx control strategy is to produce $\mathrm{H}_{2}-\mathrm{CH}_{4}$ mixtures through two-phase anaerobic digestion, where two digester tanks are operated in series, with the first one producing a majority $\mathrm{H}_{2}$ and the second $\mathrm{CH}_{4}$. The resulting mixture of $\mathrm{H}_{2}, \mathrm{CH}_{4}$, and $\mathrm{CO}_{2}$ should combust with low $\mathrm{NOx}$ emissions. Furthermore, in theory, if the biogas from the second-phase is sparged through the first-phase, $\mathrm{H}_{2}$ would be stripped from the first-phase liquid medium, and $\mathrm{H}_{2}$ production would be more thermodynamically favored, possibly increasing $\mathrm{H}_{2}$ production.

Laboratory experiments were used to determine the optimal conditions to generate biogas with a 15:85 $\mathrm{H}_{2}: \mathrm{CH}_{4}$ ratio using two phase digestion with glucose as the substrate. Specifically, the objectives of this thesis were to (1) determine the optimal conditions for operating the first-phase to produce $\mathrm{H}_{2}$, (2) 
determine the sparging rate required to achieve $15: 85 \mathrm{H}_{2}: \mathrm{CH}_{4}$ in the biogas, and (3) operate the first and second-phases together with second-phase biogas being sparged through first-phase medium to achieve $15: 85 \mathrm{H}_{2}: \mathrm{CH}_{4}$. The results from each of these objectives are described below.

(1) The optimal conditions for $\mathrm{H}_{2}$ production in the first-phase were an organic loading rate of $22.9 \mathrm{~g} \mathrm{COD/L-day} \mathrm{(chemical} \mathrm{oxygen} \mathrm{demand)} \mathrm{and} \mathrm{a} \mathrm{hydraulic}$ residence time of 12 hours. The resulting $\mathrm{pH}$ in the first-phase was 6.11 when operated under these conditions. Optimized hydrogen production in the first phase resulted in the generation of $1.02 \pm 0.13 \mathrm{~L} \mathrm{H}_{2} / \mathrm{L}_{\text {digester-day, which can also }}$ be expressed as $0.61 \pm 0.10 \mathrm{~mol} \mathrm{H} / 2 \mathrm{~mol}$ glucose consumed, $_{\text {, }} 0.42 \pm 0.06 \mathrm{~mol} \mathrm{H}_{2} / \mathrm{mol}$ glucose $e_{\text {introduced }}, 1.06 \pm 0.16 \mathrm{~mol} \mathrm{H}_{2} / \mathrm{mol} \mathrm{COD}_{\text {destroyed }}$, and $0.06 \pm 0.01 \mathrm{~mol} \mathrm{H} / \mathrm{mol}$ $\mathrm{COD}_{\text {introduced. }}$

(2) Initial sparging experiments were conducted using nitrogen $\left(\mathrm{N}_{2}\right)$ to represent second-phase biogas. The rates tested ranged from 1- $30 \mathrm{~L} \mathrm{~N}_{2} / \mathrm{L}_{\text {first-phase digester }}-\mathrm{hr}$. A $1.1 \mathrm{~L}$ gas/L-hr sparging rate was projected to result in a $15: 85 \mathrm{H}_{2}: \mathrm{CH}_{4}$ ratio. The projection was made using a power regression model $\left(R^{2}=0.99\right)$ of sparging rate vs. hydrogen content results, assuming the sparged $\mathrm{N}_{2}$ was replaced with typical biogas $\left(60 \% \mathrm{CH}_{4}\right.$ and $\left.40 \% \mathrm{CO}_{2}\right)$.

(3) When both phases were integrated, the second-phase produced enough gas to sparge at only $0.28 \mathrm{~L}$ gas $/ \mathrm{L}_{\text {first-phase digester }}-\mathrm{hr}$, which was far less than the

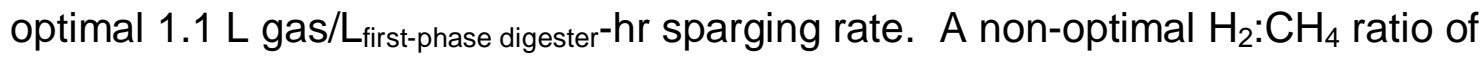


15:12 was obtained at the $0.28 \mathrm{~L}$ gas/L-hr sparging rate. Insufficient $\mathrm{CH}_{4}$ was generated due to the low organic loading provided to the second-phase.

Although the $1.1 \mathrm{~L}$ gas $/ \mathrm{L}-\mathrm{hr}$ sparging rate was not tested in an integrated system, the results obtained from the $0.28 \mathrm{~L}$ gas $/ \mathrm{L}$-hr sparging rate differed from what was predicted by the nitrogen sparging model by only $14 \%$. Therefore, the model was fairly accurate (at least at a low flow rate of $0.28 \mathrm{~L}$ gas $/ \mathrm{L}-\mathrm{hr}$ ) and could still be valid for the predicted optimal flow rate of $1.1 \mathrm{~L}$ gas $/ \mathrm{L}-\mathrm{hr}$.

For future two-phase digestion studies, biogas production from the second-phase can be increased by adding more substrate to the second-phase or by using fixed-film digesters to possibly increase the number density of methanogens. It is also recommended to digest practical waste feedstocks, and possibly digest different feedstocks in the first and second-phases. Also, the effects of carbon dioxide on the combustion characteristics and NOx emissions of hydrogenmethane mixtures in biogas need to be researched. 


\section{ACKNOWLEDGMENTS}

I would like to acknowledge the following people and organizations for helping me achieve my research goals and supporting me while I attended Cal Poly:

- Ruth Spierling: It was great working with you. Thank you for being an excellent, dedicated, and patient supervisor. I appreciate all the things you've helped me with on this project and as a student, and for letting me struggle and fail at times. Your supervision has made me become a better engineer and I will be forever grateful for that.

- Tryg Lundquist: Thank you for choosing me to work on this project, teaching me the ways of wastewater engineering, providing me guidance, and editing my thesis.

- John Benemann: I appreciate the insight you provided to better improving my research.

- San Luis Obispo Wastewater Reclamation Facility Staff: Thank you for letting me grab sludge every few weeks and for still letting me visit even after I dropped a sample bottle into one of the digester standpipes!

- California Energy Commission (CEC) \& Agricultural Research Institute (ARI): Thank you for the funding which supported my thesis project.

- Yarrow Nelson \& Gregory Schwartz: Thank you for being on my thesis committee and providing additional feedback on my project.

- Shelley Blackwell: I am grateful for your help in managing my undergraduate research assistants, taking care of purchasing items for my project, and ensuring the labs were well-stocked.

- Tracy Thatcher: Thank you for letting me borrow your air flow calibration meter and being an excellent advisor and teacher. 
- Neal Adler, Sean Thomson, \& Kyle Fooks: Thank you for letting me work on your thesis projects and giving me valuable research experience as an ENVE 400 student.

- Chris Pittner, Erik Hoffnagle, \& Hayley Baker: Thank you for working on the more intricate parts of my project, whether it was operating and maintaining the digester system independently, constructing gas meters, or conducting lab tests. It was great working with all of you.

- All ENVE 400/405 Students: I appreciate all the work you put into helping me carry out my project. Without you this research would not have been possible. In the words of NBA superstar Kevin Durant: "You da real MVP."

- My Fellow Graduate Students: It was great working with you in the labs and going through the thesis experience together.

- Amy Sinclair, Kay Kibbe, and Xi Shen: Thanks for ensuring the school vehicles were kept in good-condition and available when I needed to go to the sewage plant.

- Cal Poly San Luis Obispo: Thank you for providing me with a quality education and the knowledge to become a good engineer.

- Merle Fry: Thanks for putting up with the Breeze Lab. Although we did not know each other too well, I know you occasionally saw sludge on the floors or smelled some funky odors. I greatly appreciate you ensuring the paper-towel and soap dispensers were always full and dealing with our waste.

- My Parents \& Steve: Thank you for supporting me in life and my education. I would have never gotten to this point without you guys.

- Marissa Carranza: Thank you for hanging in there through the ups-and-downs of my project, and for always being someone I could bounce ideas off of. I am glad to have had you as my partner-in-crime during this project. 


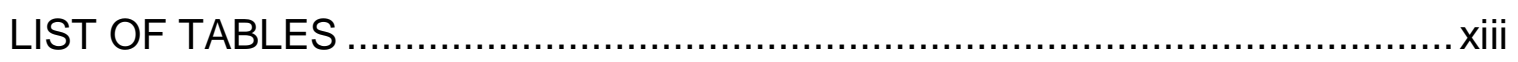

LIST OF FIGURES ….......................................................................

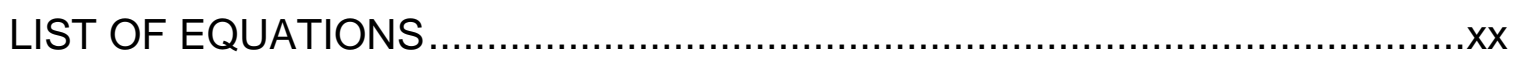

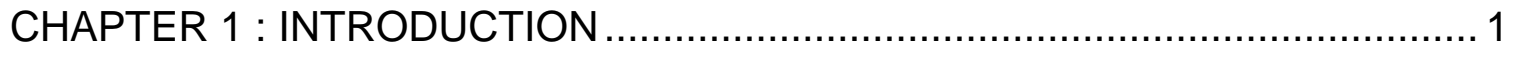

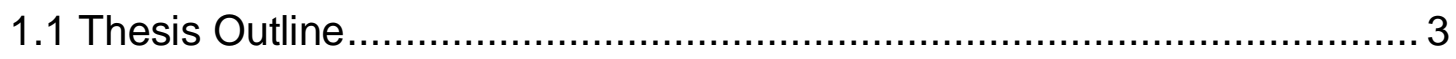

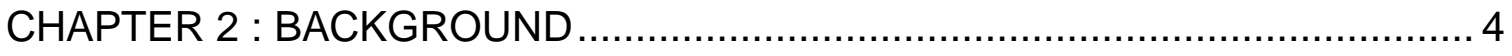

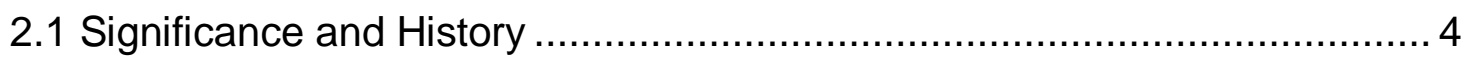

2.1.1 Greenhouse Gases and How Dairy Farms Contribute to Emissions ... 4

2.1.2 Reducing GHG Emissions with Controlled Anaerobic Digestion.......... 5

2.1.3 NOx Emission Problems from Combusting Biogas ............................. 6

2.1.4 Hydrogen Addition to Reduce NOx Emissions from Farm Digesters ... 7

2.1.5 Hydrogen Production, Storage, and Transportation Issues ................ 9

2.1.6 Fermentative Hydrogen Production ............................................... 9

2.1.7 Two-Phase Anaerobic Digestion as the Solution.............................. 10

2.2 Anaerobic Digestion Fundamentals .................................................... 11

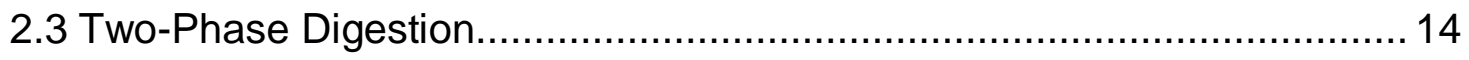

2.3.1 Methods to Produce Hydrogen in the First-Phase ............................ 14

2.4 Previous Studies on Fermentative Hydrogen Production ....................... 16

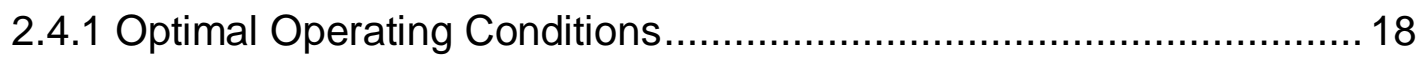

2.4.2 Issue of Low Molar Hydrogen Yields ............................................. 21

2.4.3 Methods to Increase Hydrogen Yields ............................................ 23

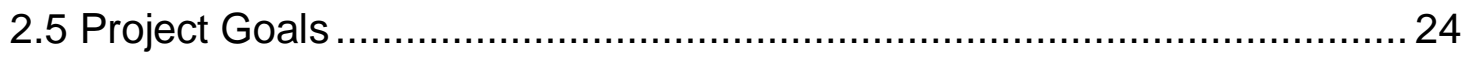

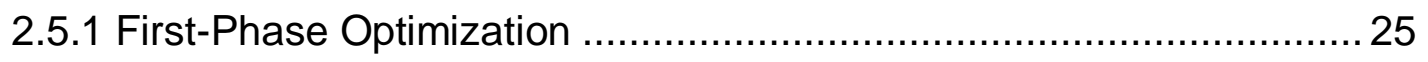

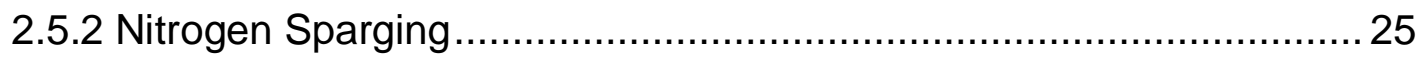

2.5.3 Integrated First and Second-Phase Operation ................................ 25

CHAPTER 3 : MATERIALS \& METHODS ……......................................... 27

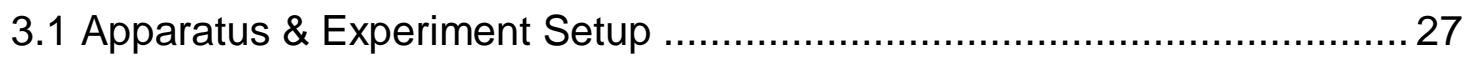

3.1.1 Design of Bench-Top Anaerobic Digesters...................................... 30 


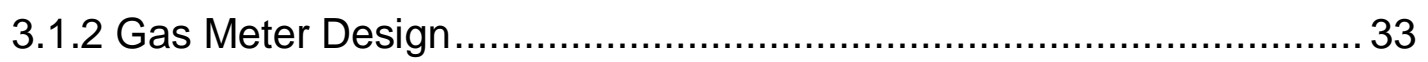

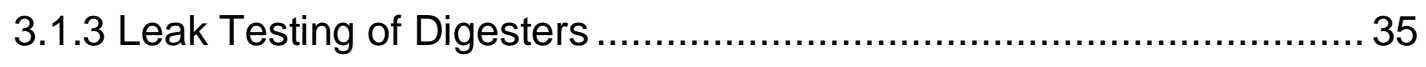

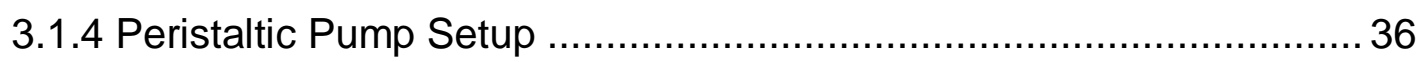

3.1.5 Feedstock Reservoir Design......................................................... 37

3.1.6 Nitrogen Sparging Experiment Apparatus .......................................... 39

3.1.7 Feedstock Ingredients \& pH Control ................................................. 40

3.1.8 Digester Inoculum Source ................................................................ 42

3.1.9 Serum Bottle Experiment Setup .................................................... 43

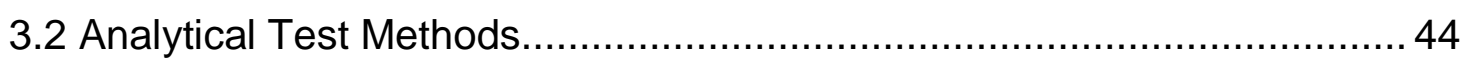

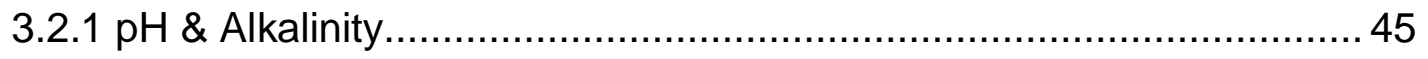

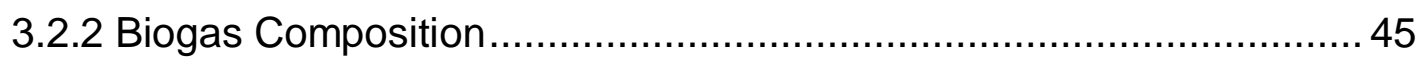

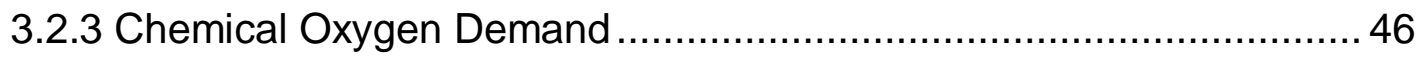

3.2.4 Total and Volatile Suspended Solids ................................................. 46

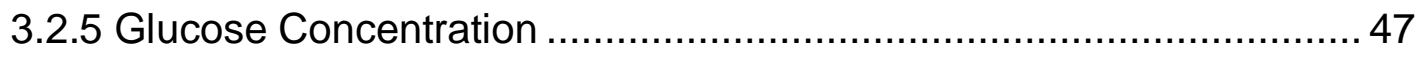

3.2.6 Quality Control Procedures........................................................... 48

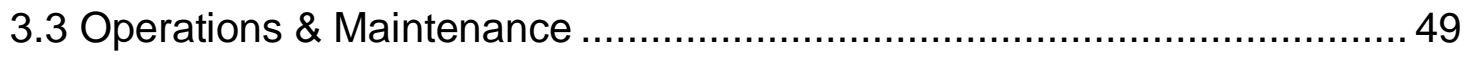

3.3.1 Experiment Startup Procedure ..................................................... 49

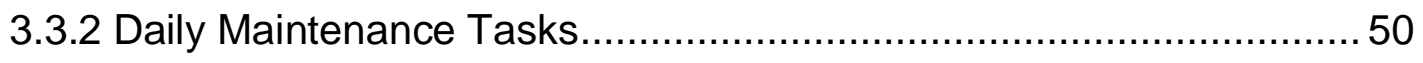

3.3.3 Steady State Data Collection ........................................................... 52

3.3.4 Experiment Shutdown Procedure .................................................. 53

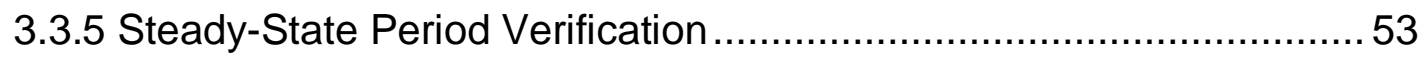

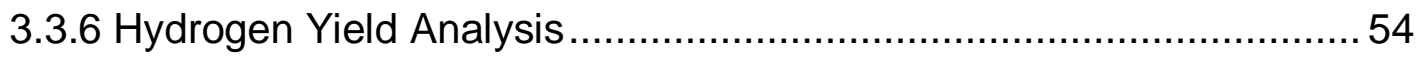

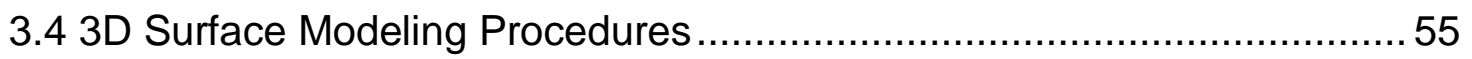

CHAPTER 4 : FIRST-PHASE OPTIMIZATION EXPERIMENTS ....................... 57

4.1 Issues with Initial First-Phase Experiments ………............................... 57

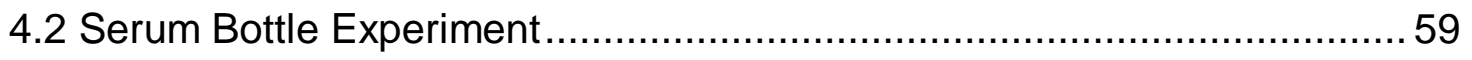

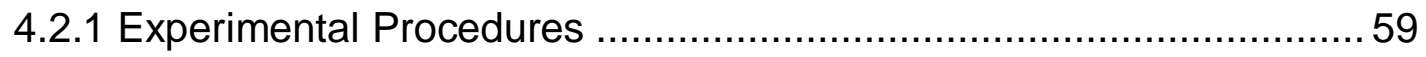

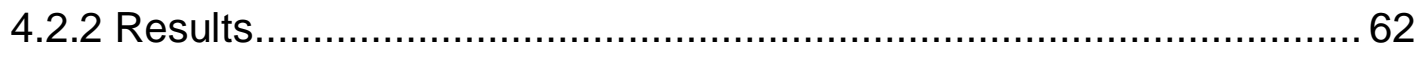

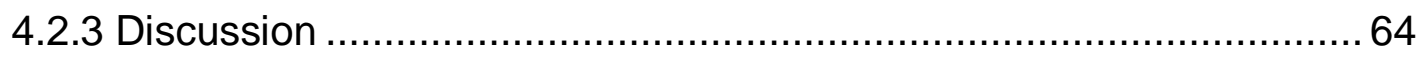

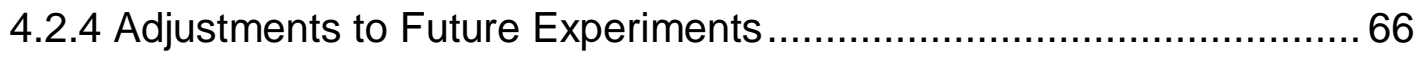


4.3 Organic Loading Rate (OLR) Testing Experiment ................................. 67

4.3.1 Organic Loading Rate Correction .................................................... 67

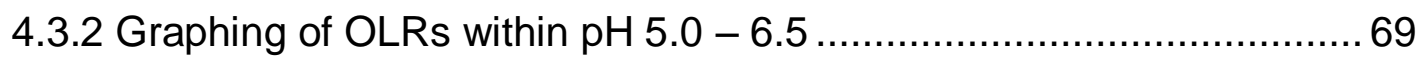

4.3.3 Volumetric Hydrogen Yields \& Hydrogen Composition...................... 69

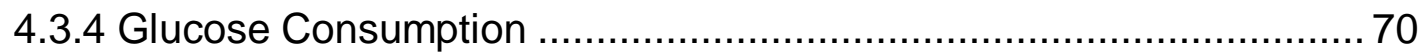

4.3.5 Glucose-Consumed \& Glucose-Introduced Hydrogen Yields ............ 72

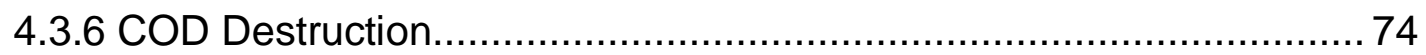

4.3.7 COD-Introduced \& COD-Destroyed Hydrogen Yields....................... 75

4.3.8 Chemical Oxygen Demand (COD) Balance....................................... 77

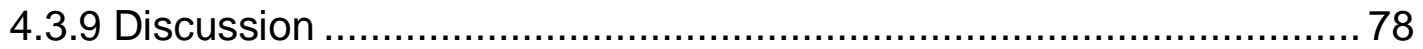

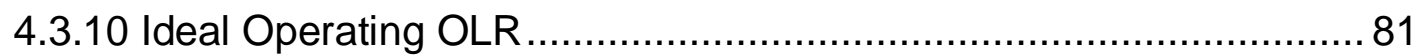

4.4 Hydraulic Residence Time (HRT) Experiment ...................................... 82

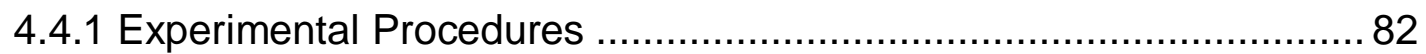

4.4.2 Volumetric Hydrogen Yields \& Hydrogen Composition...................... 83

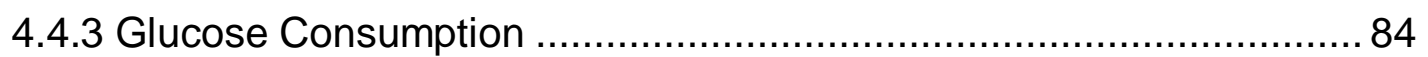

4.4.4 Glucose-Consumed \& Glucose-Introduced Hydrogen Yields ............ 86

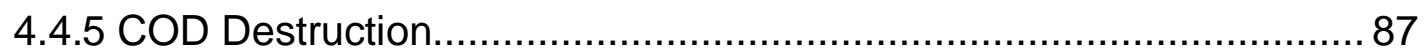

4.4.6 COD-Introduced \& COD-Destroyed Hydrogen Yields....................... 88

4.4.7 Chemical Oxygen Demand (COD) Balance....................................... 89

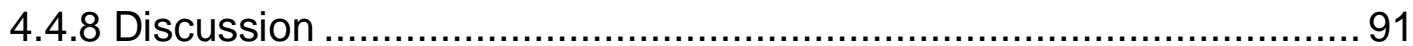

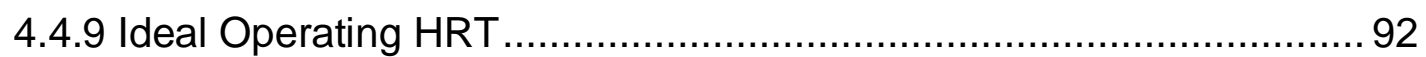

4.5 3D Surface Model Summary................................................................ 93

CHAPTER 5 : NITROGEN SPARGING \& INTEGRATED FIRST AND

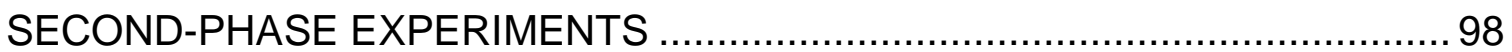

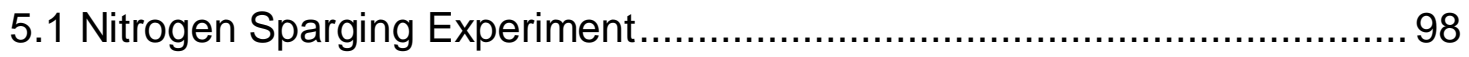

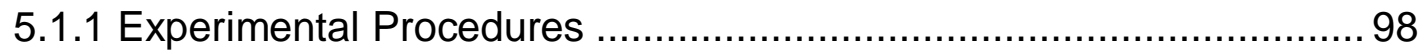

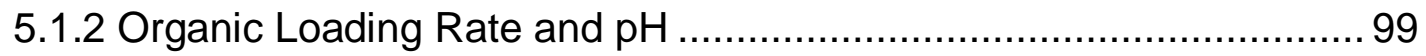

5.1.3 Volumetric Hydrogen Yields ..................................................... 100

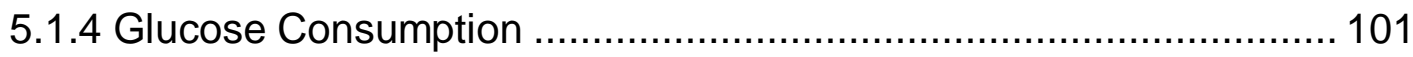

5.1.5 Glucose-Consumed \& Glucose-Introduced Hydrogen Yields .......... 101 


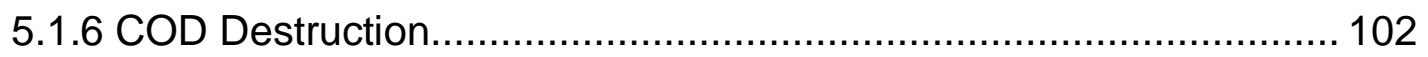

5.1.7 COD-Destruction \& COD-Introduced Hydrogen Yields.................... 102

5.1.8 Chemical Oxygen Demand (COD) Balance.................................... 104

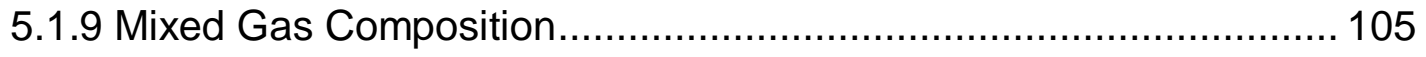

5.1.10 Hydrogen Composition Prediction Model..................................... 105

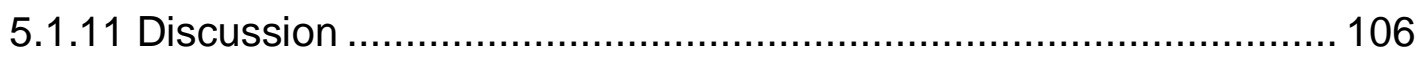

5.2 Integrated First and Second-Phase Experiment ................................... 107

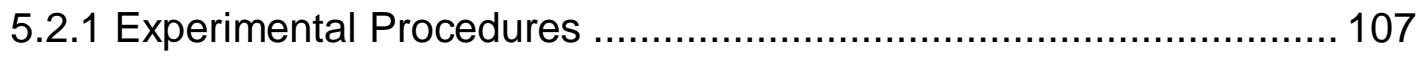

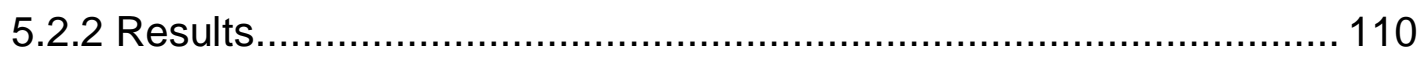

5.2.3 Second-Phase COD Balance .................................................... 111

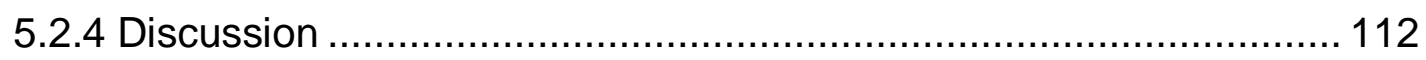

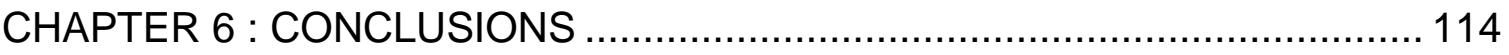

6.1 Experimental Conclusions ….................................................................. 114

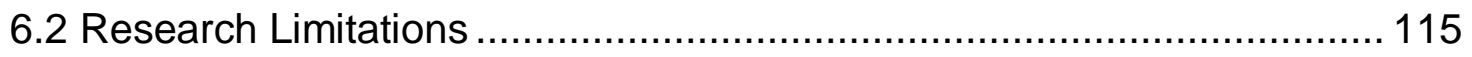

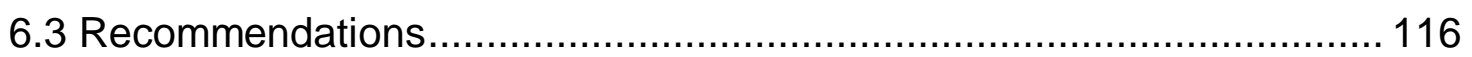

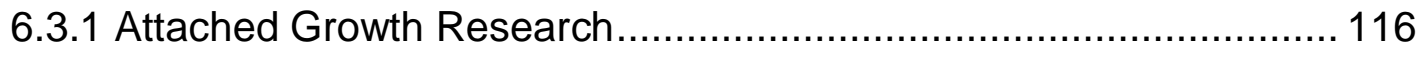

6.3.2 Practical Substrates for Hydrogen Production ................................. 118

6.3.3 Digestion of Different Substrates in the First-Phase ….................... 118

6.3.4 Fixed Film Second-Phase Digesters............................................. 119

6.3.5 Digester Volume Ratio Optimization ............................................. 119

6.3.6 Methane Reformation of Biogas to Hydrogen ............................... 120

6.3.7 Effect of $\mathrm{CO}_{2}$ on Combustion Characteristics of $\mathrm{H}_{2} / \mathrm{CH}_{4}$ Blends ...... 120

6.3.8 Effect of Mixing on $\mathrm{H}_{2}$ Production ............................................... 121

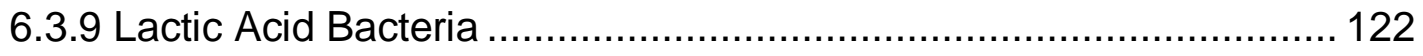

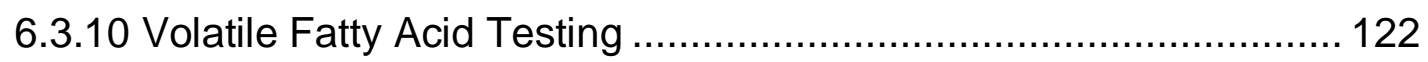

6.3.11 Testing Realistic Sparging Rates.............................................. 123

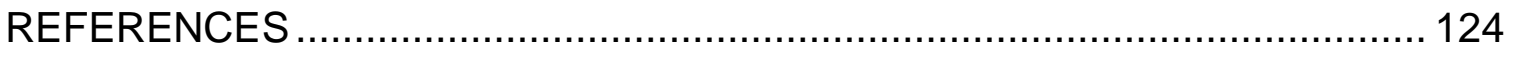

APPENDICES

Appendix A - Second-Phase Gas Production Rate Calculations ................ 130 


\section{LIST OF TABLES}

Table

Page

Table 2-1: Effect of emission controls on NOx emissions from IC engines (Wilson, 2012)

Table 2-2: Summary of ideal operating conditions for fermentative hydrogen production from the studies discussed in Section 2.4.1.

Table 2-3: Gibbs Free Energy of Formation ( $\Delta \mathrm{G}^{\circ}$ ) and theoretical molar $\mathrm{H}_{2}$ yields for the various pathways of glucose degradation in fermentative hydrogen production (Karakashev \& Angelidaki, 2011)

Table 3-1: Descriptions of the types of $\mathrm{H}_{2}$ yields analyzed for all $1^{\text {st }}$-phase optimization 54

Table 4-1: Setup used for the Serum Bottle Experiment to aid in determining which feedstock nutrient solution was ideal, and to troubleshoot why the initial first-phase experiments had low yields. Each serum bottle (165-mL capacity) had a total of $100-\mathrm{mL}$ liquid volume.

Table 4-2: $\mathrm{pH}$, Alkalinity, and $\mathrm{H}_{2}$ production results for the Serum Bottle Experiment. This experiment lasted eight days.

Table 4-3: Feedstock glucose concentrations, COD concentrations, and calculated GLRs for all target GLRs and pHs tested. The feedstock glucose concentration expected based on COD measurements and the organic loading rate $(\mathrm{OLR})$ in terms of COD were also calculated.

Table 4-4: Volumetric $\mathrm{H}_{2}$ yields, and $\mathrm{H}_{2}$ composition measured for all organic loading rates and $\mathrm{pHs}$ tested at a constant 12-hr hydraulic residence time (HRT).

Table 4-5: Influent (feedstock) glucose, effluent glucose, glucose consumed, and \% glucose consumption at all organic loading rates (OLRs) tested at a constant 12-hr hydraulic residence time (HRT).

Table 4-6: $\mathrm{H}_{2}$ yields on a glucose-consumed and glucose-introduced basis for all organic loading rates (OLRs) and $\mathrm{pHs}$ tested at a constant 12-hr hydraulic residence time (HRT). 
Table 4-7: Influent (feedstock) COD, effluent COD, and \% COD destruction at all organic loading rates (OLRs) tested at a constant 12-hr hydraulic residence time (HRT).

Table 4-8: $\mathrm{H}_{2}$ yields on a COD-destroyed and COD-introduced basis for all organic loading rates (OLRs) and pHs tested at a constant 12-hr hydraulic residence time (HRT).

Table 4-9: COD Balance for all organic loading rates (OLRs) tested. 77

Table 4-10: $\mathrm{H}_{2}$ yield summary for the ideal OLR of $22.9 \mathrm{~g}$ COD/L-day 82

Table 4-11: Summary of hydraulic residence times (HRTs) and steady-state pHs tested for the HRT experiment. All HRTs were operated at a constant organic loading rate (OLR) of $22.9 \mathrm{~g}$ COD/L-day

Table 4-12: Volumetric $\mathrm{H}_{2}$ yields, and $\mathrm{H}_{2}$ composition measured for all hydraulic residence times (HRTs) and pHs tested in the HRT experiment (all operated at a target organic loading rate (OLR) of $22.9 \mathrm{~g} \mathrm{COD/L-day)}$

Table 4-13: Influent (feedstock) glucose, effluent glucose, glucose consumed, and \% glucose consumption at all hydraulic residence times (HRTs) and pHs tested at a target organic loading rate (OLR) of $22.9 \mathrm{~g}$ COD/L-day

Table 4-14: $\mathrm{H}_{2}$ yields on a glucose-consumed and glucose-introduced basis for all hydraulic residence times (HRTs) and pHs tested.

Table 4-15: Influent (feedstock) COD, effluent COD, and \% COD destruction at all hydraulic residence times (HRTs) tested 88

Table 4-16: $\mathrm{H}_{2}$ yields on a COD-destroyed and COD-introduced basis for all hydraulic residence times (HRTs) and pHs tested.

Table 4-17: COD Balance for all HRTs tested. Percent (\%) recovery was calculated as Effluent COD +H2 COD Calculated/Influent COD $\times 100 \%$

Table 4-18: $\mathrm{H}_{2}$ yield summary for the ideal HRT of $12 \mathrm{hrs}$ compared to other HRTs tested (within pH 5.0 - 6.5) 
Table 4-19: Maximum theoretical $\mathrm{H}_{2}$ yield values predicted by the 3D surface models and their corresponding operating conditions

Table 5-1: Organic loading rates (OLRs) and pHs at all sparging rates tested. The target OLR was $22.9 \mathrm{~g} \mathrm{COD/L-day.}$

Table 5-2: Influent (feedstock) glucose, effluent glucose, glucose consumed, and $\%$ glucose consumption at all sparging rates tested.

Table 5-3: Influent (feedstock) COD, effluent COD, and \% COD destruction at all sparging rates tested.

Table 5-4: COD Balance for all sparging rates tested.

Table 5-5: Measured $\mathrm{H}_{2}, \mathrm{CO}_{2}$, and $\mathrm{N}_{2}$ biogas compositions at all sparging rates tested. Estimated mixed gas compositions and $\mathrm{H}_{2}: \mathrm{CH}_{4}$ ratios are also shown

Table 5-6: Data summary for the first and second-phases in the integrated experiment. 


\section{LIST OF FIGURES}

$\begin{array}{ll}\text { Figure } & \text { Page }\end{array}$

Figure 2-1: Simplified overall proposed two-phase digestion system process using dairy manure as a potential feedstock. Hydrogen and methane are generated, respectively, in the 1st and second-phases by manipulating the average amount of time bacteria spend in each digester (HRT: Hydraulic Residence Time).

Figure 2-2: The four general steps of anaerobic digestion. Overall, organic matter is converted to the end products $\mathrm{CH}_{4}, \mathrm{CO}_{2}$, and nutrient-rich digestate (remaining matter after anaerobic digestion). Image from (Cooke, 2014).

Figure 3-1: System used for conducting all first-phase and $\mathrm{N}_{2}$ sparging experiments. The digester bottles were wrapped with heating pads covered with aluminum insulation.

Figure 3-2: Flow schematic for the first-phase digestion experiments. This particular setup was used for OLR experiments. For HRT experiments, pump tubing was configured differently (described in Section 3.1.1). Each component of the system is described in further detail in Sections 3.1.1 - 3.1.5.......

Figure 3-3: Schematic of a first-phase $\left(\mathrm{H}_{2}\right)$ anaerobic digester. The vessel rested on a stir plate and was wrapped in an electric heating pad. The protuberance shown on the top of the vessel represents the threaded cap for the bottle, which was sealed with Teflon tape to prevent gas leaks.

Figure 3-4: Schematic of the biogas flow. Gas produced in the digesters was directed through 6.4-mm ID tubing to a custom-built tipping gas meter. A 1-L Tedlar bag was used to accommodate changes in the liquid volume of the digester due to uneven pumping and slight temperature swings

Figure 3-5: Schematic of gas meters used for measuring gas production from the anaerobic digesters (Fresco, 2015). Note: The dimensions used for the gas meter in this drawing are a few centimeters larger than the gas meters used for this project. 
Figure 3-6: Schematic of a feedstock reservoir. The reservoirs were 20-L, continuously-mixed, and kept inside a refrigerator at $4^{\circ} \mathrm{C}$.

Figure 3-7: Experimental apparatus used for measuring biogas production from serum bottles (Hill, 2014). The serum bottles in this figure are from a different study using algae.

Figure 4-1: Cumulative hydrogen produced per for each serum bottle set. Note: Only Set 8 and Set 7 produced significant amounts of hydrogen in this experiment.

Figure 4-2: Volumetric $\mathrm{H}_{2}$ yields measured for all organic loading rates (OLRs) tested at a constant hydraulic residence time (HRT) of $12 \mathrm{hrs}$.

Only OLRs operated between $\mathrm{pH} 5.0-6.5$ are graphed. 70

Figure 4-3: Glucose consumption for all organic loading rates (OLRs) tested between $\mathrm{pH} 5.0-6.5$.

Figure 4-4: $\mathrm{H}_{2}$ yields on a glucose-consumed and glucose-introduced basis at all organic loading rates (OLRs) tested at a constant hydraulic residence time (HRT) of $12 \mathrm{hrs}$. Only OLRs operated between pH $5.0-6.5$ are graphed.

Figure 4-5: $\mathrm{H}_{2}$ yields on a COD-destroyed and COD-introduced basis at all organic loading rates (OLRs) tested at a constant hydraulic residence time (HRT) of 12 hrs. Only OLRs operated between pH $5.0-6.5$ are graphed. ........ 76

Figure 4-6: COD balance at all organic loading rates (OLRs) and pHs tested.... 78

Figure 4-7: Volumetric $\mathrm{H}_{2}$ yields measured for all hydraulic residence times (HRTs) tested at a target organic loading rate (OLR) of $22.9 \mathrm{~g} \mathrm{COD/L-day}$ and between $\mathrm{pH} 5.0-6.5$.

Figure 4-8: Glucose consumption at all hydraulic residence times (HRTs) tested between $\mathrm{pH} 5.0$ and 6.5 .

Figure 4-9: $\mathrm{H}_{2}$ yields on a glucose-consumed and glucose-introduced basis at all hydraulic residence times (HRTs) tested. Only HRTs operated between pH $5.0-6.5$ are graphed. 
Figure 4-10: $\mathrm{H}_{2}$ yields on a COD-destroyed and COD-introduced basis at all hydraulic residence times (HRTs) tested. Only HRTs operated between pH $5.0-6.5$ are graphed.

Figure 4-11: COD balance at all hydraulic residence times (HRTs) tested. 90

Figure 4-12: Volumetric $\mathrm{H}_{2}$ Yield vs. HRT vs. OLR (within $\mathrm{pH} 5.0$ - 6.5). This surface model predicts a maximum volumetric $\mathrm{H}_{2}$ yield of $1.02 \mathrm{~L} \mathrm{H}_{2} / \mathrm{L}$-day at a 13.0-hr HRT and an OLR of $23.2 \mathrm{~g} \mathrm{COD/L-day.}$

Figure 4-13: Glucose-consumed $\mathrm{H}_{2}$ Yield vs. HRT vs. OLR (within $\mathrm{pH} 5.0-6.5$ ). This surface model predicts a maximum glucose-consumed $\mathrm{H}_{2}$ yield of $1.20 \mathrm{~mol} \mathrm{H}_{2} / \mathrm{mol}$ glucose consumed $_{\text {at }}$ a $19.6-\mathrm{hr}$ $\mathrm{HRT}$ and an OLR of $26.1 \mathrm{~g} \mathrm{COD/L-day.}$

Figure 4-14: Glucose-introduced $\mathrm{H}_{2}$ Yield vs. HRT vs. OLR (within $\mathrm{pH} 5.0-6.5$ ). This surface model predicts a maximum glucose-introduced $\mathrm{H}_{2}$ yield of $0.48 \mathrm{~mol} \mathrm{H}_{2} / \mathrm{mol}_{\text {glucose }}$ introduced at a 15.6-hr $\mathrm{HRT}$ and an OLR of $20.3 \mathrm{~g}$ COD/L-day.

Figure 4-15: COD-destroyed $\mathrm{H}_{2}$ Yield vs. HRT vs. OLR (within $\mathrm{pH} 5.0$ - 6.5). This surface model predicts a maximum COD-destroyed $\mathrm{H}_{2}$ yield of $1.08 \mathrm{~mol}$ $\mathrm{H}_{2} / \mathrm{mol} \mathrm{COD}_{\text {destroyed }}$ at an 11.6-hr HRT and an OLR of $25.2 \mathrm{~g} \mathrm{COD/L-day.}$

Figure 4-16: COD-introduced $\mathrm{H}_{2}$ Yield vs. HRT vs. OLR (within $\mathrm{pH} 5.0$ - 6.5). This surface model predicts a maximum COD-introduced $\mathrm{H}_{2}$ yield of $0.06 \mathrm{~mol}$ $\mathrm{H}_{2} / \mathrm{mol} \mathrm{COD}_{\text {introduced }}$ at a 14.0-hr HRT and an OLR of $19.5 \mathrm{~g} \mathrm{COD/L-day.}$

Figure 5-1: Volumetric $\mathrm{H}_{2}$ yields measured at all sparging rates tested. 100

Figure 5-2: $\mathrm{H}_{2}$ yields on a glucose-consumed and glucose-introduced basis, and percent glucose consumed (for reference) at all sparging rates tested ..... 102

Figure 5-3: $\mathrm{H}_{2}$ yields on a COD-destroyed and COD-introduced basis at all sparging rates tested.

Figure 5-4: COD balance at all sparging rates tested. 104

Figure 5-5: Actual sparging rate vs. measured $\% \mathrm{H}_{2}$ for the $\mathrm{N}_{2}$ sparging experiment. 
Figure 5-6: Schematic of the integrated first and second-phase experiment .... 109

Figure 5-7: COD Balance for the second-phase digesters ............................ 112

Figure 5-8: Measured and predicted $\% \mathrm{H}_{2}$ at a sparging rate of

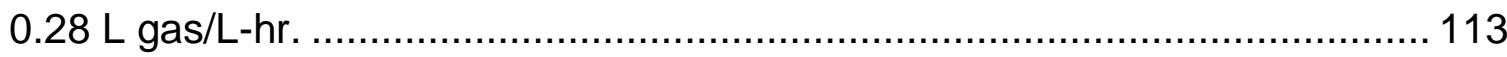

Figure 6-1: Attached growth occurred on the tubing in the inside of the digesters and the inner walls. 


\section{LIST OF EQUATIONS}

Equation

Page

Equation 2-1: Acetate Formation. 13

Equation 2-2: Butyrate Formation.... 13

Equation 2-3: $\mathrm{CH}_{4}$ Formation Pathway 1 13

Equation 2-4: $\mathrm{CH}_{4}$ Formation Pathway 2 14

Equation 2-5: $\mathrm{CH}_{4}$ Formation Pathway 3 . 14

Equation 2-6: Glucose Loading Rate (GLR) Equation 19

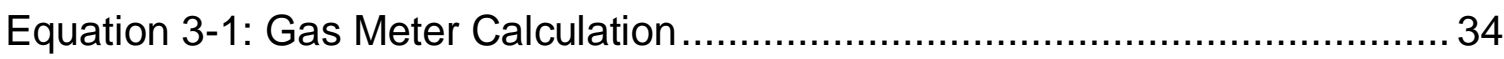

Equation 3-2: Hourly Pumping Volume Calculation ........................................ 37

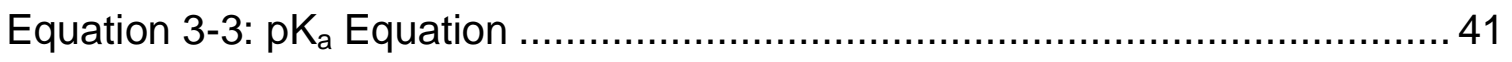

Equation 3-4: GLR Correction Calculation..................................................... 47

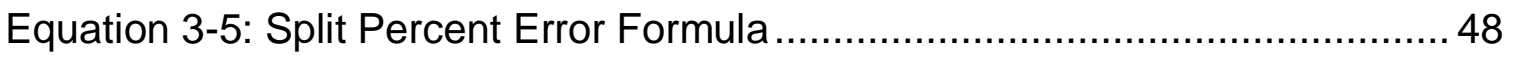

Equation 3-6: Spike Percent Recovery Formula ........................................... 48 


\section{CHAPTER 1: INTRODUCTION}

Anaerobic digestion is an appealing method for managing and treating biodegradable wastes because it converts organic matter into potentially useful biogas, primarily of methane $\left(\mathrm{CH}_{4}\right)$ and carbon dioxide $\left(\mathrm{CO}_{2}\right)(\mathrm{CEC}, 2015)$. While $\mathrm{CH}_{4}$ and $\mathrm{CO}_{2}$ are both greenhouse gases (GHGs), if the biogas is collected, it can be combusted to generate electricity and heat (Bracmort, 2010), potentially offsetting fossil fuel use (DOE, 2013).

Most dairy farms in California use anaerobic, open lagoons to store and treat cow waste (Spierling et al., 2009), but many do not currently collect biogas for combustion (USEPA, 2010, 2015). Instead, the waste is allowed to anaerobically ferment, releasing $\mathrm{CH}_{4}$ and $\mathrm{CO}_{2}$ into the atmosphere (Bracmort, 2010). One reason farmers have been deterred from collecting biogas is the high capital and maintenance costs associated with using air pollution control equipment to control the nitrous oxide (NOx) emissions that result from biogas combustion (ESA, 2011).

With increasing regulations enacted to reduce GHG emissions in California, such as the Global Warming Solution Act (AB32) and Executive Order B-30-15, the State government is interested in reducing GHG emissions from many types of sources (CARB, 2015). Dairy farms are candidates for GHG reductions because open lagoons emit $\mathrm{CH}_{4}$ and $\mathrm{CO}_{2}$ (Bracmort, 2010).

Controlled anaerobic digestion, where biogas is collected and burned instead of allowed to escape into the atmosphere (Metcalf \& Eddy, 2013), is an increasingly 
appealing option for dairy farms in California because it can reduce GHG emissions significantly (Bracmort, 2010). However, most dairies in California are in the San Joaquin Valley, which is a severe non-attainment area for ozone (CalEPA, 2011). Thus, finding a cost-effective way to reduce NOx emissions from biogas combustion is an issue that needs to be resolved before anaerobic digestion becomes more widely used for California dairies.

A potential NOx emissions control strategy that might be financially feasible is to enrich the biogas with hydrogen (Kornbluth et al., 2012). Studies have shown that hydrogen-methane mixtures at a ratio of approximately $15 \% \mathrm{H}_{2}$ to $85 \% \mathrm{CH}_{4}$ by volume (henceforth referred to as $15: 85 \mathrm{H}_{2}: \mathrm{CH}_{4}$ ), burn with significantly lower NOx emissions when combusted at ultra lean air-to-fuel ratios (Choudhuri \& Gollahalli, 2000; Collier, Hoekstra, Mulligan, Jones, \& Hahn, 1996; Shrestha \& Karim, 1999; Sierens, 1998). This strategy is appealing since it could potentially eliminate or reduce the need for costly post-combustion NOx control devices, such as catalytic converters.

One way $\mathrm{H}_{2}-\mathrm{CH}_{4}$ mixtures can be produced is by manipulating the anaerobic digestion process to produce an excess of $\mathrm{H}_{2}$ in addition to $\mathrm{CH}_{4}$ and $\mathrm{CO}_{2}$. Hydrogen is produced during anaerobic digestion by particular groups of bacteria, but the hydrogen is typically consumed by methanogenic bacteria, to produce $\mathrm{CH}_{4}$ (WtERT, 2009). If the hydrogen-formers can be separated from the methanogens in a separate digester (or reactor), while another digester includes both groups of bacteria, it is possible to have both hydrogen and methane as end-products (Cooney et al., 2007). This method of generating $\mathrm{H}_{2}-\mathrm{CH}_{4}$ mixtures 
is known as two-phase anaerobic digestion (Cooney et al., 2007). The term "two-phase digestion" is also commonly used to describe digester reactors operated in series but without excess $\mathrm{H}_{2}$ production (Metcalf \& Eddy, 2013), but in the present work it will be used to mean a $\mathrm{H}_{2}$-producing phase followed by a $\mathrm{CH}_{4}$-producing phase.

\subsection{Thesis Outline}

This thesis project was an attempt to achieve the 15:85 $\mathrm{H}_{2}: \mathrm{CH}_{4}$ ratio using a laboratory scale, two-phase digestion system fed glucose. Real waste substrates were not used because this was a proof-of-concept project, and it was easier to control the organic loading into the system with glucose as the substrate.

The remaining chapters in this thesis cover this project's scientific background and goals, the system design and setup, testing methods, and experimental procedures. Results from all experiments are discussed, and conclusions and recommendations for future research are made from these results. 


\section{CHAPTER 2: BACKGROUND}

In this chapter, the history and backdrop for this project are discussed in more detail. Also, the fundamentals of anaerobic digestion, two-phase digestion, fermentative hydrogen production, and research goals of this project are described.

\subsection{Significance and History}

The overall significance, background, and events that led to the development of this project, which were briefly summarized in Chapter 1 , are discussed further in this section.

\subsubsection{Greenhouse Gases and How Dairy Farms Contribute to Emissions} Since the mid $20^{\text {th }}$-century, greenhouse gases (GHGs) have been a major contributor to climate change (USEPA, 2014a). $\mathrm{CH}_{4}$ and $\mathrm{CO}_{2}$ are the most commonly emitted GHGs in the U.S, with $\mathrm{CH}_{4}$ having 21 times more global warming potential than $\mathrm{CO}_{2}$ over a 100-year period (USEPA, 2014b).

In 2012, $36 \%$ of anthropogenic $\mathrm{CH}_{4}$ emissions in the United States came from agricultural sources (The White House, 2014). Besides enteric fermentation $\left(\mathrm{CH}_{4}\right.$ emissions by livestock), manure is the second leading source of $\mathrm{CH}_{4}$ emissions in the agriculture sector (USEPA, 2014b). $\mathrm{CH}_{4}$ emitted to the atmosphere from the biological breakdown of manure is a lost opportunity to combust the gas for heat and electricity and a significant contributor to climate change. 
Uncontrolled $\mathrm{CH}_{4}$ emissions are commonplace at dairy farms using lagoons to store manure (Bracmort, 2010). In the Central Valley of California, where approximately 1,500 dairy farms are located, most animals are housed in barns and corrals (Pettygrove, Putnam, \& Meyer, 2003). Roughly two-thirds of these farms flush water through the alleys to remove cow waste (Krich et al., 2005). The used flush water is usually stored in an anaerobic lagoon (Spierling et al., 2009). Waste reduction is achieved as the manure undergoes anaerobic respiration in the lagoon, but the manure is partly converted to biogas which is released into the atmosphere. Waste lagoons are also exposed to the air and subject to low temperatures, making them inefficient at degrading waste and a source of VOC emissions (odor) (Krich et al., 2005).

With greenhouse gas regulations, the California state government is increasingly interested in reducing GHG emissions, particularly from stationary sources such as dairy waste lagoons. The Global Warming Solutions Act (AB32) and Executive Order B-30-15 require Californians to reduce their GHG emissions (CARB, 2015), leading to increased urgency to divert GHGs from dairy and animal waste and to generate carbon offset credits as a potential revenue source.

\subsubsection{Reducing GHG Emissions with Controlled Anaerobic Digestion}

A solution for reducing both waste and GHG emissions is controlled anaerobic digestion. In a controlled environment, better conditions for anaerobic respiration are provided, resulting in accelerated waste reduction. Additionally, biogas is captured instead of released into the atmosphere. The biogas can be used to 
produce electricity which may further reduce carbon emissions by offsetting fossil fuel consumption.

Controlled anaerobic digestion is an appealing option because it is relatively inexpensive, easy to operate, reduces sludge volume, and can eliminate pathogens (Metcalf \& Eddy, 2013). For example, wastewater treatment plant digesters are mixed and heated to speed sludge mass reduction. A covered anaerobic lagoon is another option where biogas is collected using a floating cover. These lagoons are typically not heated or mixed.

Despite its benefits, controlled anaerobic digestion has not been widely adopted for reducing waste and GHGs from dairy farms due to barriers such as local regulations, fuel and electricity rates, maintenance concerns, and poor operator knowledge and skill (USDA, 2009). The USEPA estimates digesters could be installed in at least 900 dairy farms in California, but as of January 2015, only 19 anaerobic digesters were operating on California dairy farms (USEPA, 2010, 2015).

\subsubsection{NOx Emission Problems from Combusting Biogas}

Another issue with controlled anaerobic digestion is that although GHGs are captured in the digesters as biogas, air pollutants, such as NOx, carbon monoxide (CO), volatile organic compounds (VOCs), and sulfur oxides (SOx), are emitted when biogas is combusted (Liang \& Pirnie, 2009). Of most importance is NOx, which can react with volatile organic compounds (VOCs) in the atmosphere to form ground-level ozone and smog. 
NOx emissions are a major concern in areas classified as nonattainment areas for ozone. In the San Joaquin Valley, for instance, where three-fourths of California's dairy cows are located (USEPA, 2013), the air basin is classified as an extreme nonattainment area for ozone and has the worst air quality in the nation (CalEPA, 2011; USEPA, 2013) Thus, the Air Board in this region has a strict NOx emission limit of 9-11 ppm @ 15\% $\mathrm{O}_{2}$ for Best Available Control Technologies (BACT), or 0.15 g-NOx/bhp-hr (CalEPA, 2011). Note: Brake horsepower (bhp) is the available power delivered by an engine at its output shaft.

Numerous NOx control technologies are available, such as catalytic converters, selective catalytic reduction (SCR), and microturbines, but they are easily fouled by biogas contaminants (hydrogen sulfide, water vapor, other trace gases) (Jones, 2008). Therefore, the biogas needs to be refined with additional , expensive, equipment before flowing through one of these devices (ESA, 2011) Biogas refinement technologies are firmly established and regularly used for large-scale applications (such as wastewater treatment plants), but even large dairy farms could not achieve the biogas production rate these technologies are typically used for (ESA, 2011). Consequently, the implementation of anaerobic digesters on dairy farms in California has been at a near standstill in part due to the technological and cost problems of controlling air emissions (ESA, 2011).

\subsubsection{Hydrogen Addition to Reduce NOx Emissions from Farm Digesters}

A potential solution to reducing NOx emissions from IC engines is to supplement the biogas with hydrogen $\left(\mathrm{H}_{2}\right)$. Hydrogen-hydrocarbon (i.e., $\mathrm{H}_{2} \& \mathrm{CH}_{4}$ ) mixtures 
combusted at lean air-to-fuel ratios burn with lower NOx emissions (0.032 to 0.10 g/bhp-hr with no emission control) than $\mathrm{CH}_{4}$ alone (0.05 to $0.15 \mathrm{~g} / \mathrm{bhp}$-hr with emission controls) (Wilson, 2012). At $15 \mathrm{H}_{2}: 85 \mathrm{CH}_{4}$ by volume, reduced NOx emissions and engine efficiency are optimized (Choudhuri \& Gollahalli, 2000; Collier et al., 1996; Shrestha \& Karim, 1999; Sierens, 1998). NOx emissions at 15:85 $\mathrm{H}_{2}: \mathrm{CH}_{4}$ are approximately 3 ppm (TerMaath, Skolnik, Schefer, \& Keller, 2006), which would meet San Joaquin's current NOx limit of 9-11 ppm and possibly more strict future limits. Hydrogen-methane mixtures burn cleaner because this allows the $\mathrm{IC}$ engine to burn in ultra-lean mode, resulting in lower flame temperatures that lead to less NOx emissions than other NOx control options (Table 2-1).

Table 2-1: Effect of emission controls on NOx emissions from IC engines (Wilson, 2012).

\begin{tabular}{|c|c|c|c|}
\hline $\begin{array}{l}\text { Engine } \\
\text { Operation }\end{array}$ & $\begin{array}{c}\text { Emission } \\
\text { Control }\end{array}$ & $\begin{array}{l}\text { Impact on } \\
\text { Emissions }\end{array}$ & $\begin{array}{c}\mathrm{NO}_{\mathrm{x}} \\
(\mathrm{g} / \mathrm{bhp}-\mathrm{hr})\end{array}$ \\
\hline Stoichiometric & None & Highest $\mathrm{NO}_{\mathrm{x}}$ emissions & 8 \\
\hline Stoichiometric & $\begin{array}{l}\text { Three-way } \\
\text { catalyst }\end{array}$ & $\begin{array}{l}\mathrm{NO}_{x} \text { reacts with } \mathrm{CO} \text { and } \mathrm{HC} \text { on } \\
\text { catalyst }\end{array}$ & 0.15 \\
\hline $\begin{array}{l}\text { Lean burn, } \\
\text { prechamber }\end{array}$ & None & $\begin{array}{l}\text { Lower combustion temperatures, } \\
\text { less } \mathrm{NO}_{x}\end{array}$ & 0.4 \\
\hline Lean burn & $\begin{array}{l}\text { SCR (not } \\
\text { feasible for } \\
\text { LFG }^{1} \text { ) }\end{array}$ & $\begin{array}{l}\mathrm{NO}_{x} \text { reacts on SCR catalyst in the } \\
\text { presence of injected ammonia }\end{array}$ & 0.05 to 0.15 \\
\hline $\begin{array}{l}\text { Lean burn } \\
\text { with hydrogen }\end{array}$ & None & $\begin{array}{l}\text { Hydrogen in fuel extends lean } \\
\text { operating limit }\end{array}$ & 0.032 to 0.10 \\
\hline
\end{tabular}




\subsubsection{Hydrogen Production, Storage, and Transportation Issues}

Some methods to produce hydrogen are steam reforming, renewable liquid reforming, electrolysis (water splitting), and dark fermentation (DOE, 2014), most of which are expensive compared with, for example, gasoline production. Steam reforming accounts for $95 \%$ of hydrogen production in the U.S, but it costs approximately three times more than gasoline per unit of energy produced. Electrolysis, another common method for producing hydrogen, is twice as expensive as steam reforming depending on electricity rates (FSEC, 2014).

Transporting hydrogen is also costly. Kornbluth et al. (2012) found the overall costs of importing commercial hydrogen for enriching landfill gas (mostly $\mathrm{CH}_{4} / \mathrm{CO}_{2}$ ) to reduce NOx emissions were $45-100 \%$ higher than NOx control alternatives not requiring fuel purchase (e.g. lean burn, SCR, microturbine).

\subsubsection{Fermentative Hydrogen Production}

For hydrogen augmentation to be economically feasible, the $\mathrm{H}_{2}$ should ideally be produced on-site. Fermentative hydrogen production, where bacteria convert an organic substrate into $\mathrm{H}_{2}$ and $\mathrm{CO}_{2}$ in an oxygen-free environment, such as an anaerobic digester, could potentially be a sustainable and financially viable method for producing $\mathrm{H}_{2}$.

The main barrier to fermentative hydrogen production is that no cost-effective method has been developed. Numerous hydrogen fermentation studies have been conducted on the laboratory scale, but many of them have suffered from low hydrogen yields (see Section 2.4.2 for a complete discussion and references). 
Also, the ideal feedstocks (e.g., glucose, sucrose) are too expensive to be viable (DOE, 2004). Many studies have been conducted in batch digester mode or used pure cultures of bacteria (J. Wang \& Wan, 2009), but for real-world applications, the digesters would likely be operated in continuous mode and certainly be fed non-sterile feedstocks harboring mixed bacterial cultures.

\subsubsection{Two-Phase Anaerobic Digestion as the Solution}

Production of hydrogen-methane mixtures on-site is possible through two-phase digestion, where two separate anaerobic digesters are operated in series. The first digester (or phase) is operated at a short hydraulic residence time (HRT) to produce $\mathrm{H}_{2}$, while the second-phase is a conventional, $\mathrm{CH}_{4}$-producing anaerobic digester. The gas from the second-phase is sparged into the first-phase to achieve an $\mathrm{H}_{2} / \mathrm{CH}_{4} / \mathrm{CO}_{2}$ mixture. If the correct sparging rate is used, the $\mathrm{H}_{2}: \mathrm{CH}_{4}$ ratio in the first-phase could possibly be achieved near the ideal $15: 85 \mathrm{H}_{2}: \mathrm{CH}_{4}$ range for reduced NOx emissions while maintaining acceptable engine efficiency (Figure 2-1). 


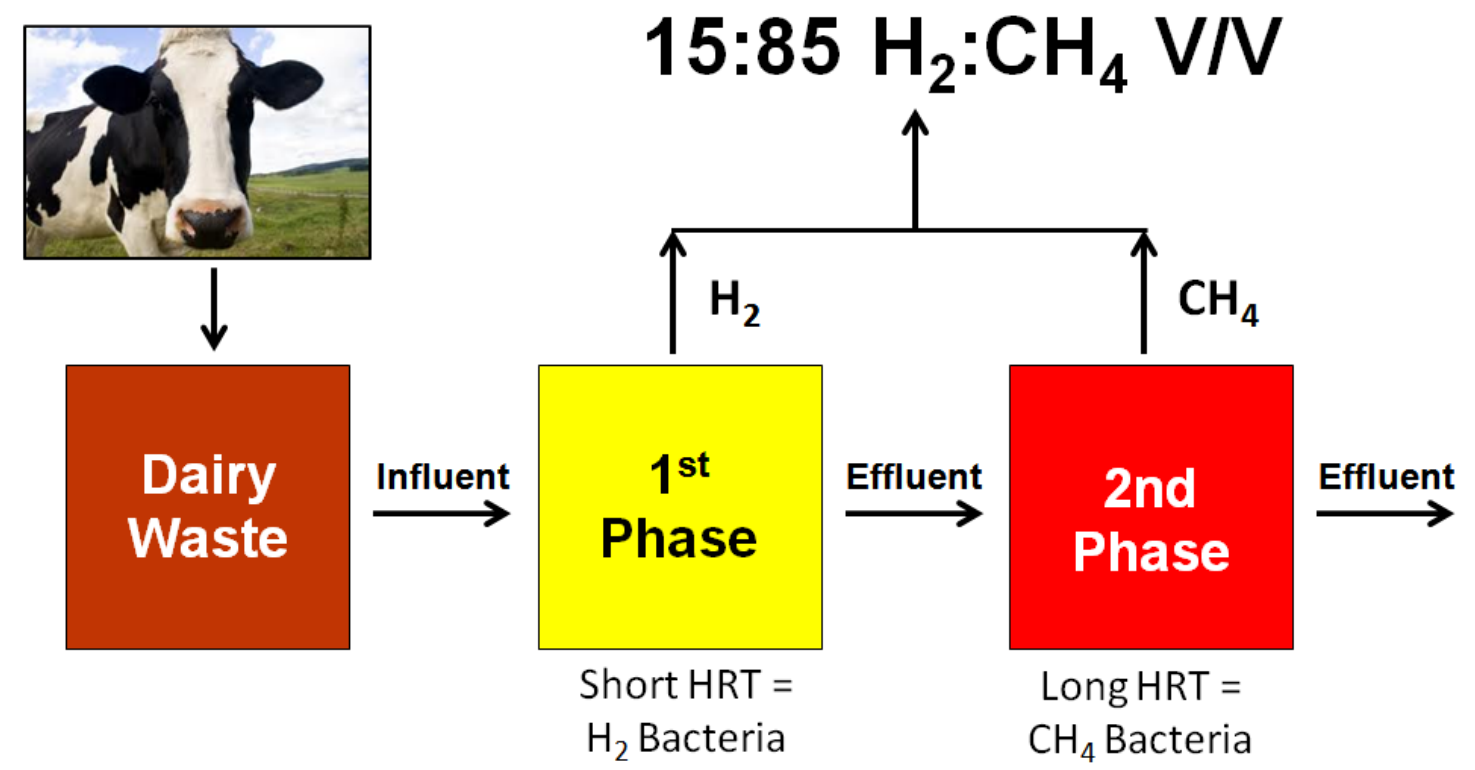

Figure 2-1: Simplified overall proposed two-phase digestion system process using dairy manure as a potential feedstock. $\mathrm{H}_{2}$ is generated in the first-phase by using a short HRT to washout slow-growing $\mathrm{CH}_{4}$-producing bacteria (methanogens) while retaining $\mathrm{H}_{2}-$ producing bacteria. $\mathrm{CH}_{4}$ is generated in the second-phase by using a long HRT to promote the growth of methanogens, which use $\mathrm{H}_{2}$ to produce $\mathrm{CH}_{4}$. This process is further described in Sections 2.2 and 2.3.

The main advantage of two-phase digestion is decreased reliance on expensive NOx control technologies while achieving a biogas with a very low NOx emission potential. While two-phase digestion could potentially solve the NOx problem, this system is operationally and biologically complex and requires more research to conclude if it is practical to operate.

\subsection{Anaerobic Digestion Fundamentals}

Anaerobic waste decomposition occurs in four general steps: (1) hydrolysis, (2) acidogenesis, (3) acetogenesis, and (4) methanogenesis (Figure 2-2). 


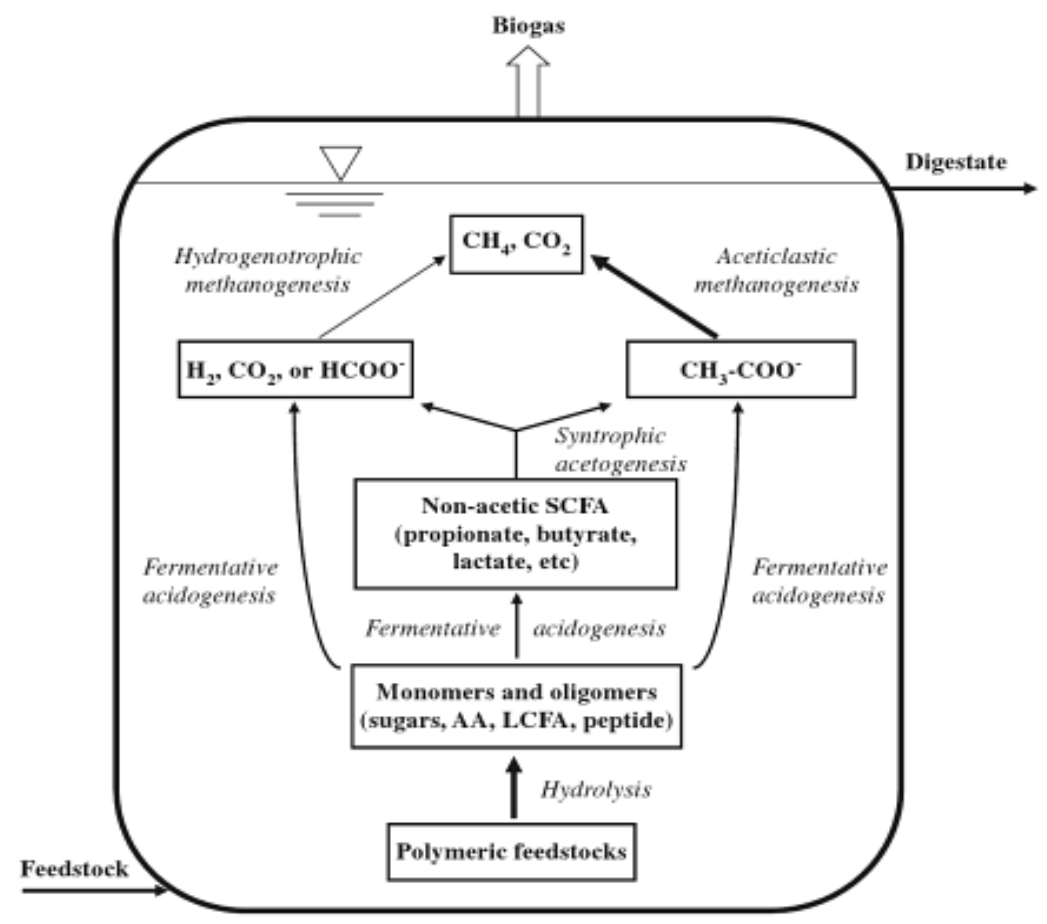

Figure 2-2: The four general steps of anaerobic digestion. Overall, feedstock (organic matter) is converted to the end products $\mathrm{CH}_{4}, \mathrm{CO}_{2}$, and nutrient-rich digestate (remaining after anaerobic digestion). Image from (Yu \& Schanbacher, 2009).

Anaerobic Digestion is an intricate process performed by a wide variety of Bacteria and Archaea (Yu \& Schanbacher, 2009). Fungi and protozoa have also been discovered in anaerobic digesters, but their contribution to anaerobic digestion is unknown (Yu \& Schanbacher, 2009). For simplicity, the term "bacteria" will refer to both Bacteria and Archaea.

In the first step, hydrolysis, bacteria break down the fats, proteins, and carbohydrates present in organic matter into simple, soluble organic compounds such as amino acids, monosaccharides, and fatty acids.

Next, bacteria convert the soluble organic matter into volatile fatty acids (e.g., acetic, propionic, butyric acid, also known as VFAs) alcohols, carbon dioxide, 
and hydrogen gas (acidogenesis). In acetogenesis, the more complex acids and alcohols formed during the previous stage are further decomposed into acetic acid $\left(\mathrm{CH}_{3} \mathrm{COOH}\right)$ and $\mathrm{H}_{2}$ and $\mathrm{CO}_{2}(\mathrm{WtERT}, 2009)$. The most common end products (besides $\mathrm{H}_{2}$ and $\mathrm{CO}_{2}$ ) of these two stages are acetate and butyrate, the disassociated forms of acetic and butyric acid, respectively. The reactions for both products are shown below with glucose as the substrate:

Equation 2-1: Acetate Formation $\mathrm{C}_{6} \mathrm{H}_{12} \mathrm{O}_{6}+2 \mathrm{H}_{2} \mathrm{O} \rightarrow 2 \mathrm{CH}_{3} \mathrm{COOH}+4 \mathrm{H}_{2}+2 \mathrm{CO}_{2}$

Equation 2-2: Butyrate Formation $\mathrm{C}_{6} \mathrm{H}_{12} \mathrm{O}_{6} \rightarrow \mathrm{CH}_{3}\left(\mathrm{CH}_{2}\right)_{2} \mathrm{COOH}+2 \mathrm{H} 2+2 \mathrm{CO}_{2}$

Because the first three steps of anaerobic digestion convert organic matter into $\mathrm{H}_{2}, \mathrm{CO}_{2}$, acetic acid, and other VFAs as end products, these processes collectively can be considered fermentative hydrogen production.

In the final step, methanogenesis, is where actual waste stabilization occurs (McCarty, 1964). Methane-forming bacteria (methanogens) convert the acetic acid and $\mathrm{H}_{2}$, formed in the preceding steps, into $\mathrm{CH}_{4}$ and $\mathrm{CO}_{2}$. The loss of $\mathrm{CH}_{4}$ from the waste solution is the mechanism of oxygen-demand removal (stabilization). The following equations represent the multiple pathways methanogens use to form the end-products of anaerobic digestion (WtERT, 2009):

Equation 2-3: $\mathrm{CH}_{4}$ Formation Pathway 1

$$
\mathrm{CO}_{2}+4 \mathrm{H}_{2} \rightarrow \mathrm{CH}_{4}+2 \mathrm{H}_{2} \mathrm{O}
$$


Equation 2-4: $\mathrm{CH}_{4}$ Formation Pathway 2

$$
2 \mathrm{C}_{2} \mathrm{H}_{5} \mathrm{OH}+\mathrm{CO}_{2} \rightarrow \mathrm{CH}_{4}+2 \mathrm{CH}_{3} \mathrm{COOH}
$$

Equation 2-5: $\mathrm{CH}_{4}$ Formation Pathway 3

$$
\mathrm{CH}_{3} \mathrm{COOH} \rightarrow \mathrm{CH}_{4}+\mathrm{CO}_{2}
$$

\subsection{Two-Phase Digestion}

The primary goal of this two-phase digestion study was to produce hydrogen in the first-phase digester and methane in the second-phase digester so the gases could be combined around an ideal ratio of $15 \mathrm{H}_{2}: 85 \mathrm{CH}_{4}$. This study differed from other types of "two-stage digestion," for example, where digestion occurs in the first digester, the second digester is used for residual sludge storage, and only $\mathrm{CH}_{4}$ and $\mathrm{CO}_{2}$ are the principal biogas products (Metcalf \& Eddy, 2013). Other "two-phase digestion" studies separated acidogenesis from methanogenesis, but with the goal of improving system stability (Demirel \& Yenigün, 2002; Ghosh, Ombregt, \& Pipyn, 1985).

\subsubsection{Methods to Produce Hydrogen in the First-Phase}

Hydrogen is produced during the fermentation and acetogenesis stages of anaerobic digestion (fermentative hydrogen production), but its concentration is kept low by methanogens. Preventing methanogens from converting $\mathrm{H}_{2}$ into $\mathrm{CH}_{4}$ (2 mol $\mathrm{H}_{2}$ used per mol $\mathrm{CH}_{4}$ created) is vital to ensuring $\mathrm{H}_{2}$ is released from the first-phase.

Hydrogen production in the first-phase can be encouraged through at least three methods: (1) using chemicals to inhibit methanogenic activity, (2) thermally 
treating the sludge to eradicate methanogens while retaining spore-forming, $\mathrm{H}_{2}-$ producing bacteria, and (3) kinetic selection.

Chemicals and heat-treatment are impractical because they do not integrate well with two-phase digestion or are energy intensive, respectively. For example, chemicals such as chloroform, sodium 2-bromoethansulfonate (BES), and iodopropane limit methanogenic activity, but this is not desirable for two-phase digestion because the effluent from the first-phase digester will be fed into the second, $\mathrm{CH}_{4}$-producing phase (Ruggeri, Tommasi, \& Sanfilippo, 2015).

Thermally treating the inoculum is not practical because it requires a large energy input (Ruggeri et al., 2015). Also, bacteria (including methanogens) are ubiquitous and could re-enter the first-phase through the influent. Instead, a more practical and economically feasible method to creating hydrogen in the firstphase is required.

"Kinetic selection" or operating the first-phase on an HRT far shorter than that used in a $\mathrm{CH}_{4}$-producing digester, can also result in $\mathrm{H}_{2}$ production in the firstphase (Ruggeri et al., 2015). Ruggeri et. al (2015) found that methanogens, or $\mathrm{H}_{2}$-consuming bacteria, have a specific growth rate $\left(\mu_{\max }\right)$ of $0.055 \mathrm{~h}^{-1}$, while $\mathrm{H}_{2-}$ producing bacteria have a $\mu_{\max }$ of $\approx 0.215 \mathrm{~h}^{-1}$ (four times higher). This difference means methanogens need a longer HRT (usually 10 days or longer) to avoid being washed-out of a completely mixed reactor. Therefore, if the HRT is lowered to favor the growth of $\mathrm{H}_{2}$-producing bacteria and attached growth is prevented, methanogens will be "washed out", and $\mathrm{H}_{2}$ will be the primary gas product of the first-phase. 
Methanogenic growth is further limited at a short HRT because the accumulation of unconsumed VFAs in the digester causes the $\mathrm{pH}$ to become too acidic for methanogens to thrive, unless sufficient buffering capacity is provided. Methanogens are metabolically active in a $\mathrm{pH}$ range of $6.6-7.6$, but if the $\mathrm{pH}$ drops below 6.2, the acidity is toxic and greatly reduces $\mathrm{CH}_{4}$ production (McCarty, 1964). Hydrogen-forming bacteria are not inhibited at acidic pHs as they operate in an optimal pH range of $5.0-6.5$ (Valdez-Vazquez \& Poggi-Varaldo, 2009).

\subsection{Previous Studies on Fermentative Hydrogen Production}

When operated at a short HRT, the biological process in the first-phase is essentially fermentative hydrogen production. Generating $\mathrm{CH}_{4}$ from organic material is a well-established method, yet large-scale fermentative hydrogen production from practical organic substrates has not been accomplished (Karakashev \& Angelidaki, 2011).

Numerous fermentative hydrogen production studies on glucose are available, yet there are typically major differences in inoculum, temperature, and digester type used (J. Wang \& Wan, 2009), which made it difficult to decide which operational conditions are best for this project. Many experiments have used sludge as an inoculum, but the digester was operated in batch mode. Conversely, some experiments were operated in continuous mode, but these studies used pure cultures of bacteria or heat-treated sludge inoculum. Heat-treated sludge is sometimes used because it removes methanogens while retaining spore-forming, hydrogen-producing bacteria (Sung, Raskin, Duangmanee, Padmasiri, \& Simmons, 2007). 
This project used non-treated anaerobic digester sludge as the inoculum, was operated at $30^{\circ} \mathrm{C}$ (mesophilic) and used continuous-flow stirred tank reactors (CSTRs) (see Section 2.5 - Project Goals, for more details). Non-treated sludge inoculum was acceptable because the low HRT in the first-phase (theoretically) caused washout of methanogens. However, this project's conditions were unusual (especially because non-treated sludge was used), and in comparison to other studies, differences in the inoculum used, substrate, feedstock nutrient solution, or digester type existed.

Studies typically express hydrogen yield as moles of hydrogen produced per mole of glucose consumed ( $\mathrm{mol} \mathrm{H}_{2} / \mathrm{mol}_{\text {glucose }}$ consumed $)$, or molar hydrogen yield. This yield indicates how efficiently bacteria are converting glucose into $\mathrm{H}_{2}$. Another measure is the volumetric hydrogen yield (volume of $\mathrm{H}_{2}$ produced per day, per volume of first-phase digester; $\mathrm{L} \mathrm{H}_{2} / \mathrm{L}$-day).

Molar and volumetric hydrogen yields were used as benchmarks in this project. Because this project used glucose as a substrate, molar hydrogen yields allowed comparison to past research. Volumetric $\mathrm{H}_{2}$ yields were useful for evaluation of sparging flow rates and the volumetric $15 \mathrm{H}_{2}: 85 \mathrm{CH}_{4}$ ratio.

Because this was a proof-of-concept project, and the ultimate goal was to prove the volumetric 15:85 $\mathrm{H}_{2}: \mathrm{CH}_{4}$ ratio could be achieved in a two-phase system, at least with glucose, molar hydrogen yield was not as important to optimize as volumetric hydrogen yield. Molar hydrogen yield is based on glucose, but ideally 
this system would be operated using wastes. Regardless, the first-phase in this project would ideally be operated at conditions optimizing both yields.

In the following sections, the ideal operational conditions and obstacles to producing $\mathrm{H}_{2}$ from glucose are discussed further.

\subsubsection{Optimal Operating Conditions}

Important operating variables to consider for producing $\mathrm{H}_{2}$ from glucose in CSTRs are the $\mathrm{pH}, \mathrm{HRT}$, and glucose loading rate. Studies generally focus on achieving the maximum molar $\mathrm{H}_{2}$ yield on a glucose-consumed basis. The ideal values identified in previous studies for these variables are described below:

- $\mathrm{pH}$ : A lower $\mathrm{pH}$ than that used for methane-producing digesters is generally more beneficial to $\mathrm{H}_{2}$ production. Fang and Liu (2002) found an optimum molar hydrogen yield of $2.1 \mathrm{~mol} \mathrm{H}_{2} / \mathrm{mol}_{\text {glucose }}$ consumed was obtained at a $\mathrm{pH}$ of 5.5 using a mixed culture taken from an existing digester that was producing hydrogen from sucrose. Similarly, Lin and Chang (1999) found at a pH of 5.7, the highest molar yield was $1.7 \mathrm{~mol}$ $\mathrm{H}_{2} /$ mol glucose $e_{\text {consumed }}$ with anaerobic sewage sludge as the inoculum. These studies used a continuous-flow digester setup with different feedstock nutrients and digester volumes than the present project used. However, even for studies that were operated in batch, used different substrates, a similar ideal $\mathrm{pH}$ range was identified. For example, Wang and $\mathrm{Mu}(2005)$ conducted batch experiments with sucrose and heat- 
treated methanogenic sludge, and found the optimum $\mathrm{pH}$ was 5.5 with a hydrogen yield of $3.7 \mathrm{~mol} \mathrm{H}_{2} / \mathrm{mol}^{\text {sucrose }}$ consumed. $_{\text {. }}$

- Hydraulic Residence Time: A short HRT (less than 24 hours) is required for hydrogen fermentation because this causes slower-growing methanogens to be washed out while faster-growing, hydrogen-forming bacteria are retained. Yet, even similar CSTR experiments that used sludge inoculum and glucose as a substrate disagree on what the best HRT is. For example, Gavala et al. (2006) found an HRT of 4 hrs produced the highest molar yield of $2 \mathrm{~mol} \mathrm{H}_{2} / \mathrm{mol}_{\text {glucose }}$ consumed. Yet, Zhang et al. (2006) observed the highest molar hydrogen yield (1.95 mol

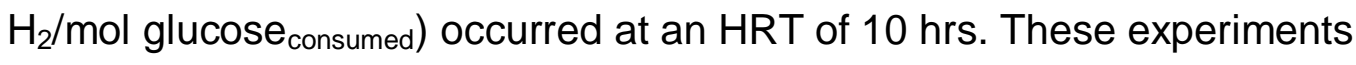
both used $10 \mathrm{~g}$ glucose/L in their feedstock, but the difference in optimum HRT might be due to differences in the type and amount of feedstock nutrients used and the inoculum source.

- Glucose Loading Rate. Another important variable is the organic loading rate (OLR) or equivalently, when glucose is the sole organic substrate, the glucose loading rate (GLR). The units of GLR are g glucose/L-day. The equation for calculating GLR is shown below:

Equation 2-6: Glucose Loading Rate (GLR) Equation $\operatorname{GLR}\left(\frac{\mathrm{g} \mathrm{C}_{6} \mathrm{H}_{12} \mathrm{O}_{6}}{\mathrm{~L} \text { digester -day }}\right)=\frac{\text { Concentration of Glucose in Feedstock }\left(\frac{\mathrm{g} \mathrm{C}_{6} \mathrm{H}_{12} \mathrm{O}_{6}}{\mathrm{~L}}\right)}{\text { Hydraulic Residence Time (day) }}$ 
Identifying the ideal GLR is complicated because it is dependent on two operational variables: the HRT and the glucose concentration. For testing for the best GLR, the HRT can be kept constant while changing the glucose concentration, or vice versa. Shen et al. (2009) performed a CSTR experiment using the former. The HRT was kept constant at $8 \mathrm{hrs}$ while changing the glucose concentration to test loading rates between $4-30 \mathrm{~g} \mathrm{COD/L-d}$. This report found the highest molar hydrogen yield of $1.80 \mathrm{~mol} \quad \mathrm{H}_{2} / \mathrm{mol}$ glucose $e_{\text {consumed }}$ was obtained at $22 \mathrm{~g} \mathrm{COD} / \mathrm{L}-\mathrm{d}$, or roughly $20.6 \mathrm{~g}$ glucose/L-day (using $1.07 \mathrm{~g} \mathrm{COD/g}$ glucose conversion factor). Additionally, Sreethawong et al. (2010) performed an experiment with an anaerobic sequencing batch reactor (ASBR) at a constant HRT of 24 hours and found at a GLR of $40 \mathrm{~g} / \mathrm{L}$-day, molar hydrogen yield was optimized at $1.46 \mathrm{~mol} \mathrm{H}_{2} / \mathrm{mol}_{\text {glucose }}$ consumed. These two experiments used different digester types and HRTs, and they identified very different ideal GLRs. This shows that the ideal GLR is highly dependent on the HRT tested, digester type, and inoculum used, and there may not be universally best OLR for fermentative hydrogen production.

Table 2-2 summarizes the ideal operating conditions identified in all studies discussed above. 
Table 2-2: Summary of ideal operating conditions for fermentative hydrogen production from the studies discussed in Section 2.4.1.

\begin{tabular}{|c|c|c|c|c|c|c|}
\hline Source & Inoculum & $\mathbf{p H}$ & $\begin{array}{l}\text { HRT } \\
\text { (hrs) }\end{array}$ & $\begin{array}{l}\text { Digester } \\
\text { Type }\end{array}$ & $\begin{array}{c}\text { GLR } \\
\text { (g/L-day) }\end{array}$ & $\begin{array}{c}\text { Molar } \mathrm{H}_{2} \text { Yield } \\
\left(\text { mol H }_{2} /\right. \\
\text { mol substrate } \\
\text { consumed })\end{array}$ \\
\hline A & $\begin{array}{l}\text { Mixed } \\
\text { Culture }\end{array}$ & 5.5 & 6 & CSTR & 28 & 2.1 \\
\hline B & $\begin{array}{l}\text { Mixed } \\
\text { Sludge }\end{array}$ & 5.7 & 6 & CSTR & 75 & 1.7 \\
\hline C & Heat-Treated & 5.5 & N/A & Batch & $\mathrm{N} / \mathrm{A}$ & $3.7^{\star}$ \\
\hline D & Heat-Treated & 6 & 4 & CSTR & 60 & 2.0 \\
\hline$E$ & Heat-Treated & 5.5 & 10 & CSTR & 24 & 1.95 \\
\hline $\mathrm{F}$ & $\begin{array}{l}\text { Mixed } \\
\text { Sludge }\end{array}$ & 5.5 & 8 & CSTR & 20.6 & 1.80 \\
\hline G & Heat-Treated & 5.5 & 24 & ASBR & 40 & 1.46 \\
\hline
\end{tabular}

${ }^{\text {A }}$ Fang \& Liu (2002)

B Lin \& Chang (1999)

${ }^{C}$ Wang \& Mu (2005)

${ }^{D}$ Gavala et al. (2006)

E Zhang et al. (2006)

F Shen et al. (2009)

G Sreethawong et al. (2010)

* This study used sucrose as substrate, all other studies used glucose.

\subsubsection{Issue of Low Molar Hydrogen Yields}

While numerous studies have produced $\mathrm{H}_{2}$ from glucose, they have all suffered from low molar hydrogen yields. In theory, the maximum hydrogen yield that can be obtained if glucose is completely consumed is $12 \mathrm{~mol} \mathrm{H}_{2} / \mathrm{mol}$ glucose $\mathrm{consumed}_{\text {, }}$ but this reaction is not thermodynamically favorable because it has a standard gibbs free energy $\left(\Delta G^{\circ}\right)$ of $+241 \mathrm{~kJ} / \mathrm{mol}$ glucose $e_{\text {consumed }}$ (Note: $\Delta G^{\circ}$ represents conditions at $25^{\circ} \mathrm{C}, 1 \mathrm{~atm}, 1 \mathrm{M}$ initial concentrations for all reactants, and $\mathrm{pH} 7.0$ ). Instead, acetate and butyrate formation are favored, with $\Delta G^{\circ}$ values of -48 $\mathrm{kJ} / \mathrm{mol}$ glucose $e_{\text {consumed }}$ and $-137 \mathrm{~kJ} / \mathrm{mol}$ glucose consumed, $_{\text {, respectively. While }}$ 
acetate formation produces $4 \mathrm{~mol} \mathrm{H}_{2} / \mathrm{mol}_{\text {glucose }} \mathrm{consumed}_{\text {and }}$ andyrate formation produces $2 \mathrm{~mol} \mathrm{H}_{2} / \mathrm{mol}_{\text {glucose }}$ consumed, these amount to far less than the stoichiometric maximum of $12 \mathrm{~mol} \mathrm{H}_{2} / \mathrm{mol}_{\text {glucose }}$ consumed, assuming no losses in the form of new cell growth (Table 2-3) (Karakashev \& Angelidaki, 2011).

Table 2-3: Gibbs Free Energy of Formation $\left(\Delta G^{\circ}\right)$ and theoretical molar $\mathrm{H}_{2}$ yields for the various pathways of glucose degradation in fermentative hydrogen production (Karakashev \& Angelidaki, 2011).

\begin{tabular}{|c|c|c|}
\hline $\begin{array}{l}\text { Chemical Process for } \\
\text { Glucose Degradation } \\
\text { in Fermentative } \\
\text { Hydrogen Production }\end{array}$ & $\begin{array}{l}\text { Gibbs } \\
\text { Free } \\
\text { Energy } \\
\left(\Delta G^{\circ}\right)^{*} \\
\end{array}$ & $\begin{array}{c}\text { Theoretical } \\
\mathrm{H}_{2} \mathrm{Yield} \\
\left(\mathrm{mol} \mathrm{H}_{2} /\right. \\
\text { Mol glucose } \\
\text { consumed })\end{array}$ \\
\hline$\underset{\text { (Stoichiometric) }}{\mathrm{C}_{6} \mathrm{H}_{12} \mathrm{O}_{6}+12 \underset{\mathrm{H}_{2} \mathrm{O} \rightarrow}{\mathrm{HCO}_{3}^{-}}+12 \mathrm{H}_{2}+6 \mathrm{H}^{+}}$ & $\frac{241 \mathrm{~kJ}}{\mathrm{~mol}}$ & 12 \\
\hline $\begin{array}{c}\mathrm{C}_{6} \mathrm{H}_{12} \mathrm{O}_{6}+4 \mathrm{H}_{2} \mathrm{O} \rightarrow 2 \mathrm{CH}_{3} \mathrm{COO}^{-} \\
+2 \mathrm{HCO}_{3}^{-}+4 \mathrm{H}_{2}+4 \mathrm{H}^{+} \\
\text {(Acetate Formation) }\end{array}$ & $\frac{-48 \mathrm{~kJ}}{\mathrm{~mol}}$ & 4 \\
\hline $\begin{array}{c}\mathrm{C}_{6} \mathrm{H}_{12} \mathrm{O}_{6}+2 \mathrm{H}_{2} \mathrm{O} \rightarrow \mathrm{CH}_{3} \mathrm{CH}_{2} \mathrm{CH}_{2} \mathrm{COO}^{-} \\
+2 \mathrm{HCO}_{3}^{-}+2 \mathrm{H}_{2}+3 \mathrm{H}^{+} \\
\text {(Butyrate Formation) }\end{array}$ & $\frac{-137 \mathrm{~kJ}}{\mathrm{~mol}}$ & 2 \\
\hline
\end{tabular}

According to Mohan (2010), typical $\mathrm{H}_{2}$ yields obtained are between 1-2 mol $\mathrm{H}_{2} / \mathrm{mol}$ glucose, with the practical limit being $2 \mathrm{~mol} \mathrm{H}_{2} / \mathrm{mol}_{\text {glucose }}$ consumed. The practical limit is lower than the theoretical $\mathrm{H}_{2}$ yields for acetate and butyrate formation. This is partly due to a portion of the energy content in glucose being converted to new cells and end-product inhibition (Mohan, 2009). As $\mathrm{H}_{2}$ is produced in the digester, the partial pressure becomes high enough to noticeably limit $\mathrm{H}_{2}$ production, resulting in lower molar yields (Westermann \& Ahring, 2006). Also, during acidogenesis, butyrate and acetate formation occur concurrently 
(see Figure 2-2). Since butyrate formation releases $2 \mathrm{~mol} \mathrm{H}_{2} / \mathrm{mol}_{\text {glucose }}$ consumed rather than the $4 \mathrm{~mol} \mathrm{H}_{2} / \mathrm{mol}_{\text {glucose }}$ consumed released during acetate formation, the average $\mathrm{H}_{2}$ yield expected from fermentative hydrogen production drops closer to the practical limit of $2 \mathrm{~mol} \mathrm{H} / \mathrm{mol}$ glucose $\mathrm{consumed}_{\text {. }}$

Theoretically, a higher yield of $4 \mathrm{~mol} \mathrm{H}_{2} / \mathrm{mol}_{\text {glucose }}$ consumed (also known as the "Thauer Limit") is attainable, but this is only possible at conditions near equilibrium or extremely low partial pressures of $\mathrm{H}_{2}$ (Hallenbeck \& Benemann, 2002).

\subsubsection{Methods to Increase Hydrogen Yields}

Hydrogen production can be made more thermodynamically favorable by lowering the $\mathrm{H}_{2}$ partial pressure in the fermenter. This can be accomplished by volatilizing $\mathrm{H}_{2}$ from the growth medium by (1) increased stirring and (2) sparging with a gas other than $\mathrm{H}_{2}$ (Das, Khanna, \& Dasgupta, 2014).

Lamed et. al (1988) studied the effects of stirring on the $\mathrm{H}_{2}$ concentration in a culture broth of Clostridium thermocellum. Without stirring, the $\mathrm{H}_{2}$ concentration in the broth was three times higher than when it was stirred at $150 \mathrm{rpm}$. Also, less acetate was produced in the unstirred broth. This study suggested stirring helps transfer $\mathrm{H}_{2}$ from the liquid phase into the gas phase (Das et al., 2014), increasing $\mathrm{H}_{2}$ yields.

Numerous experiments have used nitrogen $\left(\mathrm{N}_{2}\right)$ and/or carbon dioxide $\left(\mathrm{CO}_{2}\right)$ to increase $\mathrm{H}_{2}$ yields by sparging these gases into the digester liquid. Mizuno et al. (2000) conducted a nitrogen sparging experiment on a glucose-fed CSTR (2.3-L 
liquid volume) and found the molar yield increased from $0.85 \mathrm{~mol} \mathrm{H} / \mathrm{mol}$ glucose $_{\text {consumed }}$ without sparging to $1.43 \mathrm{~mol} \mathrm{H}_{2} / \mathrm{mol}_{\text {glucose }}$ consumed $_{\text {with }}$ sparging at $110 \mathrm{~mL} / \mathrm{min}(2.9 \mathrm{~L} \mathrm{~N} / \mathrm{L}-\mathrm{hr})$. Similarly, Kim. et al. (2006) performed a gas sparging experiment with multiple flow rates of $\mathrm{N}_{2}$ and $\mathrm{CO}_{2}(100,200,300,400$ $\mathrm{mL} / \mathrm{min}$ ) on a CSTR operated at $40 \mathrm{~g}$ sucrose COD/L-day and 12-hr HRT, with a liquid volume of $5.0 \mathrm{~L}$. The highest $\mathrm{H}_{2}$ yield of $1.68 \mathrm{~mol} \mathrm{H}_{2} / \mathrm{mol}$ hexose $\mathrm{consumed}$ was obtained at a $\mathrm{CO}_{2}$ sparging rate of $300 \mathrm{~mL} / \mathrm{min}\left(3.6 \mathrm{~L} \mathrm{CO}_{2} / \mathrm{L}\right.$-hr) compared to $0.77 \mathrm{~mol} \mathrm{H}_{2} / \mathrm{mol}_{\text {hexose }}$ consumed without sparging.

\subsection{Project Goals}

The main goal of this project was to demonstrate that biogas with a $\mathrm{H}_{2}: \mathrm{CH}_{4}$ ratio of near 15:85 could be generated through continuous, two-phase digestion of glucose, with sparging of second-phase biogas into the first-phase reactor. The main tasks to achieve this goal were the following:

1. Identify the HRT and OLR in the first-phase for optimizing hydrogen yields (more details provided in Section 2.5.1)

2. Test different biogas sparging rates from the second-phase into the firstphase to develop a model of hydrogen composition versus sparging rate, and use this model to predict which sparging rate achieved 15:85 $\mathrm{H}_{2}: \mathrm{CH}_{4}$

3. Integrate the first and second-phases using the optimal conditions identified from the first two objectives 
The relative volume of the first and second-phase digesters was another variable needing optimization. However, due to time-constraints, a fixed first-phase: second-phase volume ratio of 1:40 was used.

\subsubsection{First-Phase Optimization}

Optimizing hydrogen production in the first-phase allowed for potentially more biogas to be combusted at the ideal $\mathrm{H}_{2}: \mathrm{CH}_{4}$ ratio than if hydrogen production was not optimized. Therefore, identifying the ideal conditions (HRT, OLR) to operate the first-phase for optimizing $\mathrm{H}_{2}$ yields was the first objective.

\subsubsection{Nitrogen Sparging}

After optimizing the first-phase, the next step was to experimentally confirm that sparging increased hydrogen yields and then to identify the sparging rate of gas from the second-phase to the first-phase to obtain a $\mathrm{H}_{2}: \mathrm{CH}_{4}$ ratio of $15: 85$.

Initially, $\mathrm{N}_{2}$ was used for sparging for convenience, and previous experiments have sparged with $\mathrm{N}_{2}$ (Mizuno et al., 2000, Kim et al., 2006). High flow rates (far greater than could realistically be generated in the second-phase) were tested to determine the maximum achievable hydrogen yield with sparging. A more reasonable sparging rate comparable to the gas production expected from the second-phase was also tested. With these data, a model was created to identify the ideal sparging rate for obtaining $15: 85 \mathrm{H}_{2}: \mathrm{CH}_{4}$.

\subsubsection{Integrated First and Second-Phase Operation}

As described above, initially the second-phase, $\mathrm{CH}_{4}$-producing digesters were operated independent of the first-phase digesters to obtain baseline data and 
ensure steady-state was reached. Later, when the first and second-phases were connected, the effluent from the first-phase was pumped into the second-phase, and the biogas from the second-phase was sparged into the first-phase at the target flow rate identified in the $\mathrm{N}_{2}$ sparging experiment, with the aim of producing the desired 15:85 $\mathrm{H}_{2}: \mathrm{CH}_{4}$ ratio for reduced NOx emissions. 


\section{CHAPTER 3: MATERIALS \& METHODS}

The digester system design, operations and maintenance procedures, and setups for all experiments, including a separate serum bottle experiment, are described in this chapter. Additionally, the analytical tests used for collecting experiment data, and the procedures used to create three-dimensional (3D) data models are discussed.

\subsection{Apparatus \& Experiment Setup}

Experiments used laboratory scale anaerobic digesters fed feedstock containing glucose and other nutrients. The digester system apparatus was kept inside a laboratory hood (Figure 3-1) to reduce odor and evacuate biogas. Custom built gas meters measured the volume of gas exiting the digesters. Peristaltic pumps were used to pump influent and effluent through the digesters. A schematic of the first-phase system setup that will be described in Sections 3.1.1 - 3.1.5 is shown in Figure 3-2. 


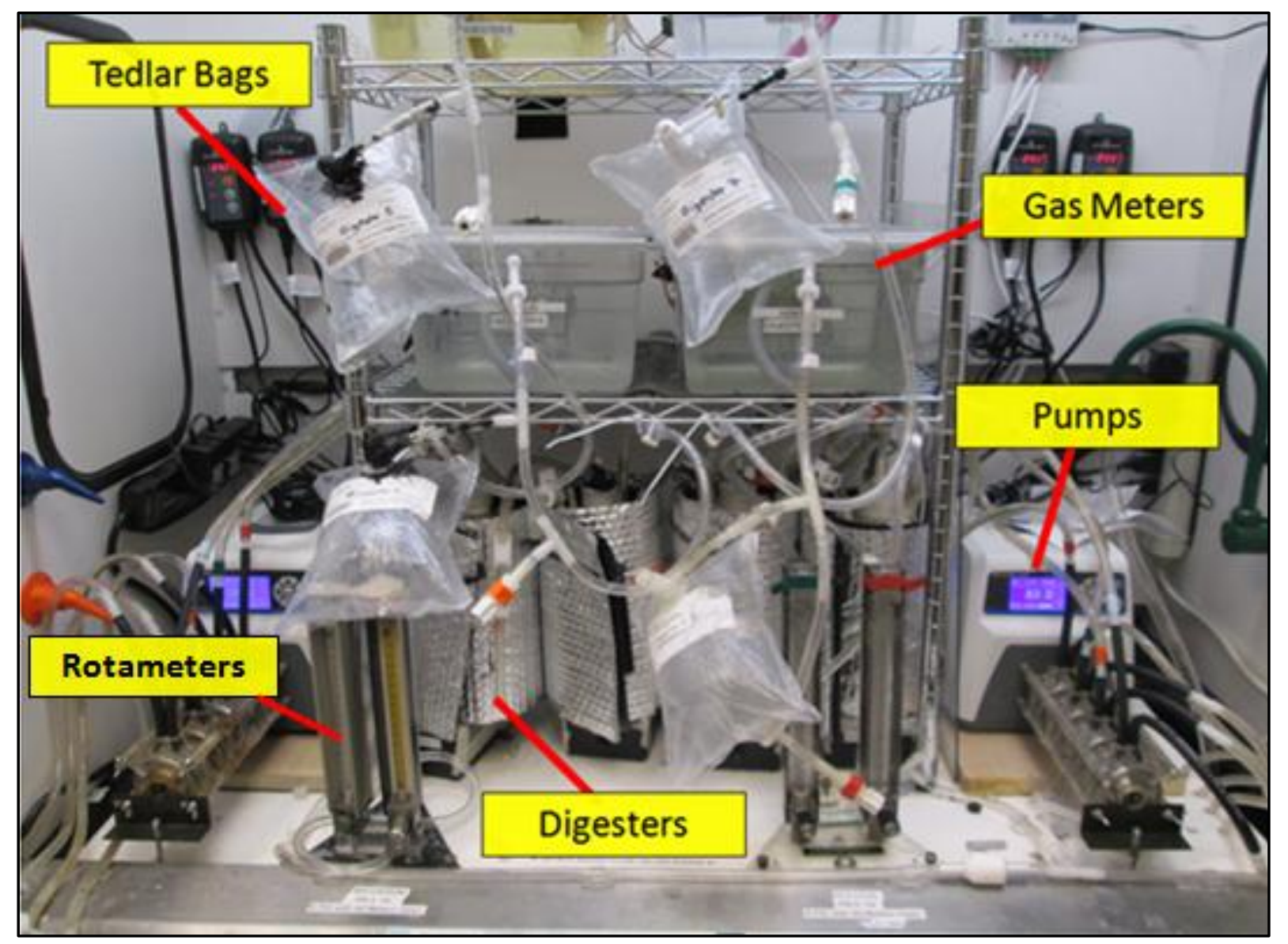

Figure 3-1: System used for conducting all first-phase and $\mathrm{N}_{2}$ sparging experiments. The digester bottles were wrapped with heating pads covered with aluminum insulation. 


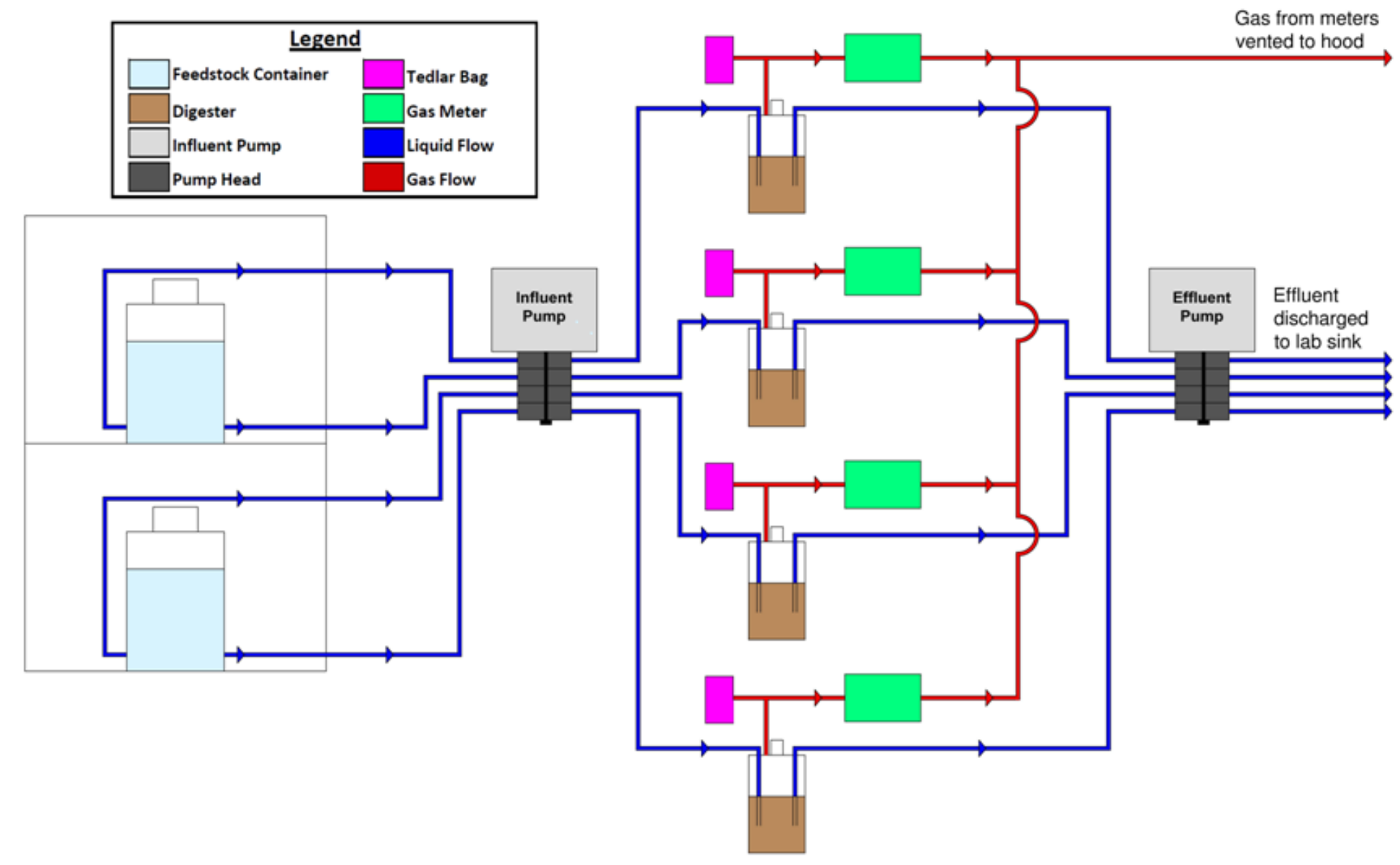

Figure 3-2: Flow schematic for the first-phase digestion experiments. This particular setup was used for OLR experiments. For HRT experiments, pump tubing was configured differently (described in Section 3.1.1). Each component of the system is described in further detail in Sections 3.1.1 - 3.1.5. 


\subsubsection{Design of Bench-Top Anaerobic Digesters}

Bench-top, continuous-flow, two-phase digesters were assembled. The firstphase digesters were 2-L fluorinated polyethylene (FLPE) bottles (Nalgene, Rochester, NY). FLPE bottles were used instead of untreated plastic bottles since fluorination prevents pressure changes in the bottle from causing the plastic walls to collapse or expand (Qorpak, 2015).

Each bottle had five holes drilled on the top shoulder for the (1) feedstock inlet, (2) effluent outlet, (3) temperature probe port, (4) sample collection port, (5) gas exit (Figure 3-3). An additional hole was drilled in the center of the threaded cap of the bottle for a sparging inlet. The bottle threads were wrapped with Teflon tape to prevent gas leaks. The temperature probe port hole was fitted with a $12.7-\mathrm{mm}$ inner diameter (ID) barbed bulkhead fitting (Thermo Fisher Scientific, Waltham, $\mathrm{MA}$ ) and deadend, 12.7-mm ID (3.2-mm thickness) polyvinyl chloride (PVC) tubing (Tygon, Saint-Gobain, Courbevoie, France) filled with water. The remaining holes were fitted with 6.4-mm ID barbed bulkhead fittings. All tubing was connected to the barbed bulkhead fittings and sealed with caulking (Kwik Seal, DAP) to prevent gas leaks. On the inside of the bottle, $6.4-\mathrm{mm}$ ID (1.6- $\mathrm{mm}$ thickness) PVC (Tygon, Saint-Gobain, Courbevoie, France) tubing extended from the inlet, outlet, and sparging inlet fittings into the 1-L liquid volume of the digester. The end of the sparging inlet was fitted with a 20-mm diameter, oval air stone for $\mathrm{N}_{2}$ or biogas sparging. 


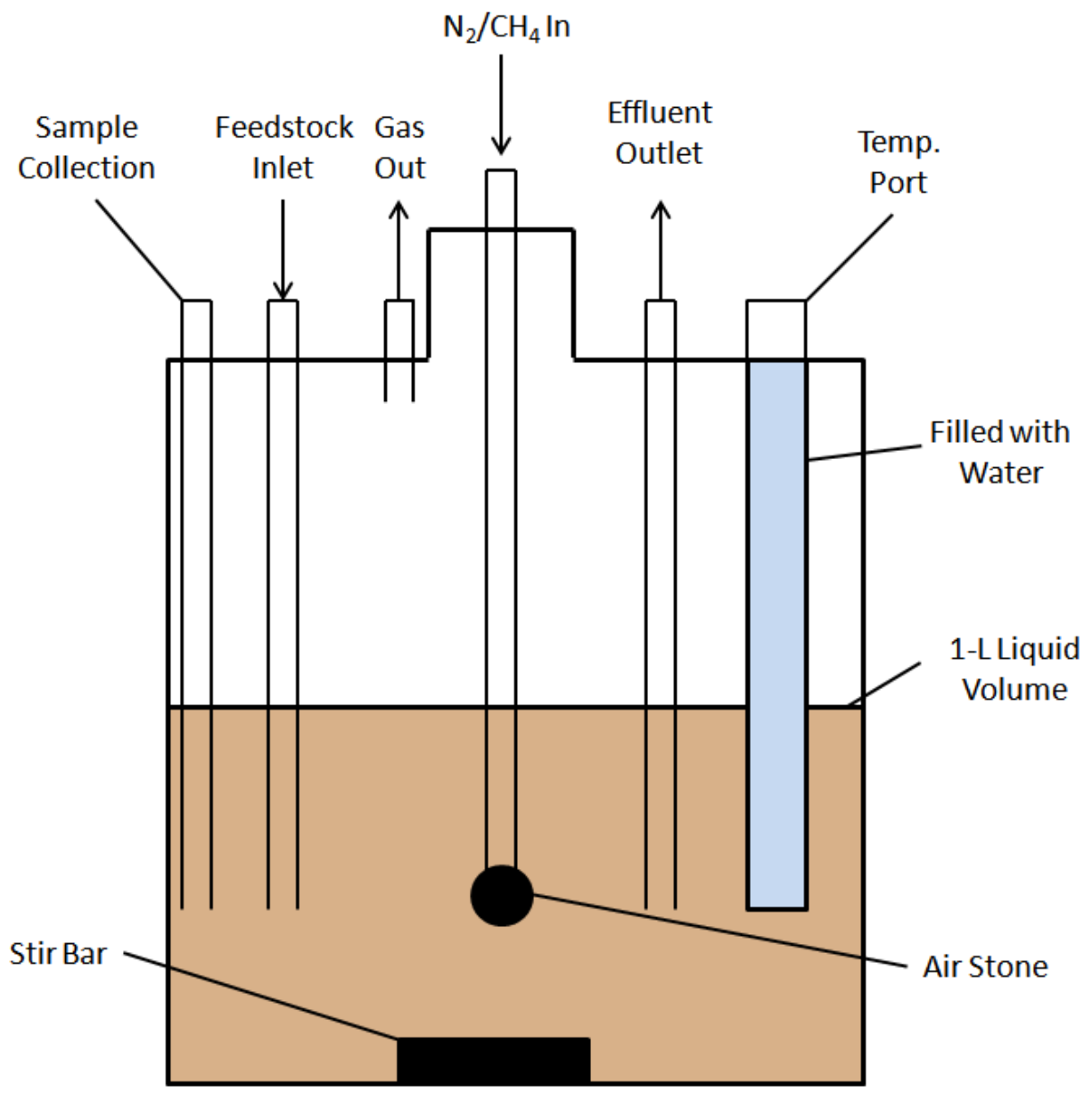

Figure 3-3: Schematic of a first-phase $\left(\mathrm{H}_{2}\right)$ anaerobic digester. The vessel rested on a stir plate and was wrapped in an electric heating pad. The protuberance shown on the top of the vessel represents the threaded cap for the bottle, which was sealed with Teflon tape to prevent gas leaks.

Seedling heat mats (Hydrofarm, Petaluma, CA) were taped onto aluminum insulation (Growers Supply, Pyersville, IA) which was wrapped around each digester with the heat mat interior to the insulation. A temperature probe compatible with the heat mat controller was submerged in the temperature port to keep the digesters at $30 \pm 2^{\circ} \mathrm{C}$. 
Magnetic, 3.8-cm Teflon-coated stir bars, powered by stir plates, were used to continuously mix the digesters. For first-phase optimization experiments, the stir plates (200 Mini Stirrer Cat No. 58940-158, VWR, Radnor, PA) were operated at about 1140 RPM. For the $\mathrm{N}_{2}$ sparging and integrated experiments, different stir plates (StirStarter, Richland, Michigan) were operated at an unintentionally lower RPM of 700 . However, mixing appeared vigorous in all of the first-phase digesters.

Gas generated in the digesters passed through the "gas out" fitting (Figure 3-3). The fitting was connected and glued with caulking to a 6.4-mm ID tube on the outside, which was linked to a 1-L Tedlar bag (Zefon International, Ocala, FL) and a tipping gas meter on the other end (Figure 3-4). The Tedlar bag allowed for unintended changes in the liquid volume of the digester without creating a vacuum in the headspace due to unequal feed-versus-effluent pumping and slight temperature fluctuations. A one-way valve was installed in the tubing between the Tedlar bag and gas meter to prevent water in the meter (see Section 3.1.2) from flowing into and filling up the bag and/or digester with water. 


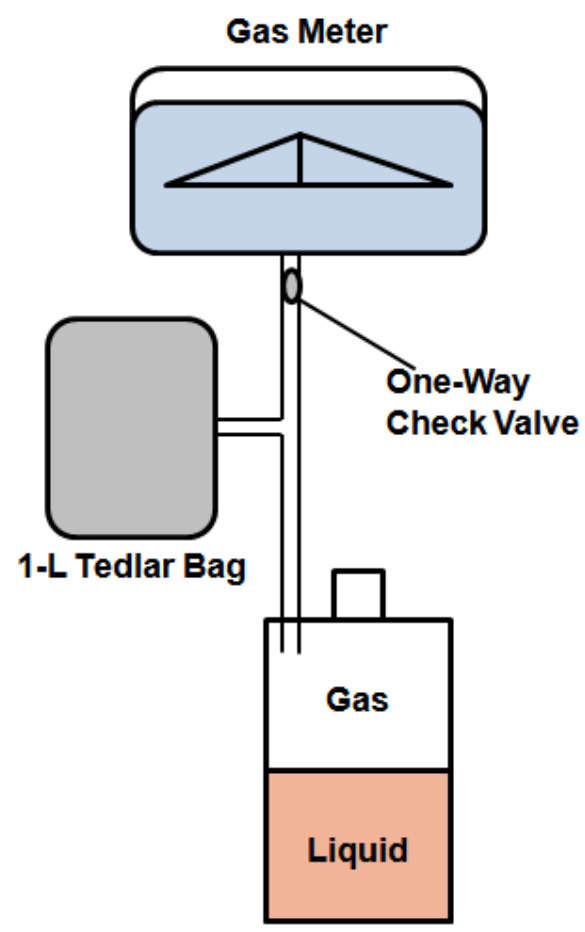

Figure 3-4: Schematic of the biogas flow. Gas produced in the digesters was directed through 6.4-mm ID tubing to a custom-built tipping gas meter. A 1-L Tedlar bag was used to accommodate changes in the liquid volume of the digester due to uneven pumping and slight temperature swings.

The second-phase $\left(\mathrm{CH}_{4}\right)$ digesters were constructed similarly to the first-phase $\left(\mathrm{H}_{2}\right)$ digesters. However, these digesters were constructed using 20-L Nalgene FLPE carboys with $20 \mathrm{~L}$ of liquid volume.

\subsubsection{Gas Meter Design}

Gas meters were used to measure the amount of gas produced by each digester. The gas meters contained two triangular chambers in a gas collection and tipping component, and the entire gas collection and tipping mechanism was submerged in a rectangular container holding water with a depth of $11.4 \mathrm{~cm}$. The gas meters were designed so that each chamber filled with a specific volume needed to cause a tip, which released the biogas to the atmosphere. Each tip either opened or closed a reed switch. The switch position was recorded with a time stamp to a 
data logger (Model HOBO UX120-017, Onset, Cape Cod, MA), which was

periodically uploaded to a computer. The amount of biogas produced daily was

calculated using the equation below:

\section{Equation 3-1: Gas Meter Calculation}

Number of tips per day $x$ tipping volume $\left(\frac{\mathrm{mL}}{\mathrm{tip}}\right)=$ Biogas produced per day

Depending on the gas meter used, $90-110 \mathrm{~mL}$ of gas needed to collect in a chamber to trigger a tip. This volume was determined using a $140-\mathrm{mL}$ syringe to measure the volume of air required to fill up each chamber causing it to tip.

During the experiments, evaporation make-up water was added to the gas meters to keep the water level the same as during calibration. However, the gas volume measured by the data loggers could be underestimated by $100 \mathrm{~mL}$ (one tip) because residual gas would sometimes remain in the chamber before a tip could occur.

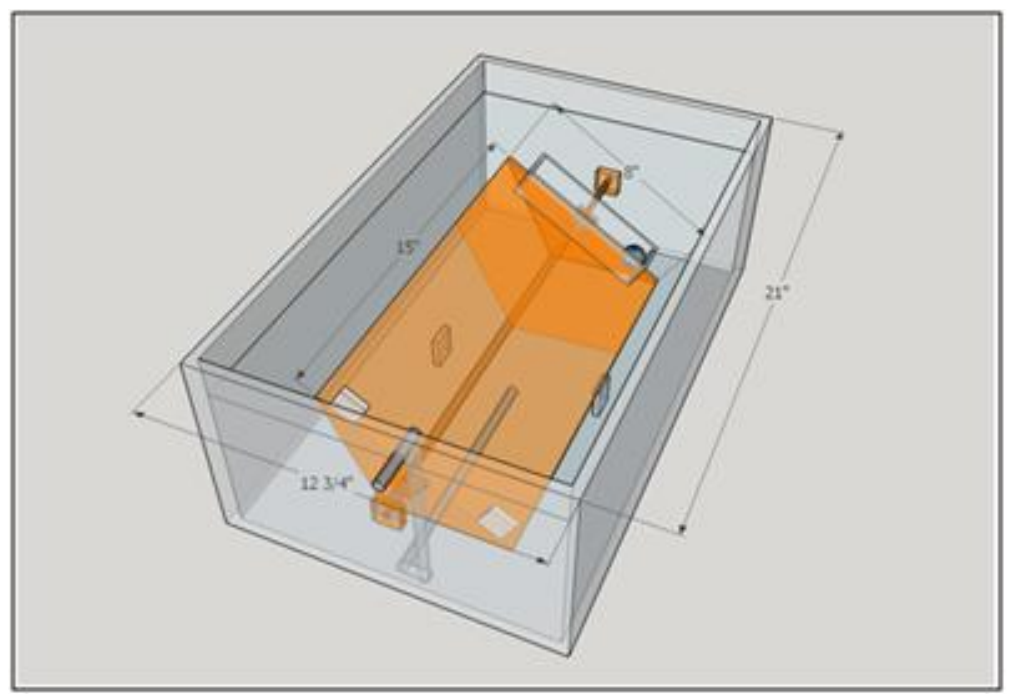

Figure 3-5: Schematic of gas meters used for measuring gas production from the anaerobic digesters (Fresco, 2015). Note: The dimensions used for the gas meter in this drawing are a few centimeters larger than the gas meters used for this project. 


\subsubsection{Leak Testing of Digesters}

To minimize gas leakage during experiments, each constructed digester was tested for leaks using two methods: (1) a short-term, high-pressure test and (2) a long-term, low-pressure test.

The short-term test consisted of filling a sink with water, pressurizing a digester with $\mathrm{N}_{2}$ to $0.4 \mathrm{~atm}$ (6 PSI), and submerging the digester underwater for at least a minute with all fittings closed. If no bubbles were observed escaping the digester fittings, the digester was then subjected to the long-term test.

For the long-term test, the digesters were filled with $1 \mathrm{~L}$ of water and all fittings except the feedstock inlet were closed. Next, a water column of approximately 61 $\mathrm{cm}(24$ ") was connected to the inlet line. If the water level in the column did not change over the course of 12 hours or longer, the digester was considered leakproof and ready to use.

Once the digesters were operating, a soap bubble test was used to check for leaks if a Tedlar gas bag was not fully inflating, or if a duplicate digester did not have similar gas production to its counterpart. Soapy water was sprayed onto the gas bag or digester, which was squeezed to force biogas into the gas meter. If any bubbles formed on the gas bag it was replaced with a new one. If the digester was leaking, the contents were temporarily stored in a beaker covered with Parafilm, and the leaky digester was swapped with a spare, leak-tested digester. The contents were poured into the replacement digester, and the headspace was re-purged with $\mathrm{N}_{2}$ to reestablish an anaerobic environment. 


\subsubsection{Peristaltic Pump Setup}

Two peristaltic pumps (Masterflex HV-07522-20, Cole-Parmer, Vernon Hills, IL) were used to pump feedstock in and effluent out of the digesters once per hour. Four pump heads (Standard Pump Head, Cole Parmer) were mounted onto the drive shaft of each peristaltic pump. Norprene tubing of 6.4-mm ID (Masterflex A$60 \mathrm{G} \mathrm{L} / \mathrm{S} 24$, Cole Parmer) was used with the pump heads because it was more durable than the digester tubing and could last longer before being worn out by the pump head rollers. Each pump head was connected to a digester and feedstock container (for pumping in) or sink (for pumping out).

Two pairs of digesters (four total), each tested at a different HRT or OLR, were operated at the same time (described further in Section 3.3.1) For HRT experiments (where HRT is varied), both the influent and effluent tubes for each digester operated at the same HRT were connected to the same peristaltic pump. For OLR experiments (where HRT is held constant), the influent tubes for all digesters, regardless of OLR tested, were connected to one peristaltic pump, and the effluent tubes were connected to the other pump (this is the setup shown in Figure 3-2).

The peristaltic pumps were calibrated by filling a feedstock reservoir with $20-\mathrm{L}$ water (with tubing already connected between the container and pump head) and measuring the volume of water pumped into a graduated cylinder at a specified rotational speed and operating time. The digesters were not connected to the pump heads during calibration because it was too difficult to accurately measure 
the pumped liquid volume while simulating the operating conditions of the digester, such as biogas pressure and varying liquid levels.

The peristaltic pumps were programmed to pump once per hour. The target water volume to be pumped per hourly cycle was calculated using Equation 3-2 below:

Equation 3-2: Hourly Pumping Volume Calculation

Volume Targeted Per Pumping Cycle $(\mathrm{mL})=\frac{1 \mathrm{~L}}{\mathrm{HRT}(\mathrm{hr})}\left(\frac{1000 \mathrm{~mL}}{\mathrm{~L}}\right)$

If the measured volume was not within $\pm 5 \%$ of the targeted volume, the pump head tubing was replaced and/or a different rotational speed and pumping time were used until the $\pm 5 \%$ criterion was met.

Pump head tubing wear was not excessive as the pumps did not operate continuously, but all pump head tubing was still changed out every couple of experiments as a safeguard.

\subsubsection{Feedstock Reservoir Design}

Sterile feedstock (recipe described in Section 3.1.7) was stored inside a refrigerator at $4^{\circ} \mathrm{C}$ in $20-\mathrm{L}$, , FLPE reservoirs (Figure 3-6) that were continuously mixed at approximately 800 RPM with magnetic, 10.2-cm Teflon-coated stir bars powered by large magnetic stirrers (MegaMag Genie, Scientific Industries, Bohemia, NY).

Two holes (outlet ports) were drilled into the reservoir walls at about $5.1-\mathrm{cm}$ from the base of the reservoir and fitted with 6.4-mm ID, barbed bulkhead fittings. 
Tubing of 6.4-mm ID was connected to each bulkhead fitting. Each tube was connected to a separate pump head on the peristaltic pumps.

The reservoirs were capped, but tubing of 6.4-mm ID was connected to the reservoir cap with a plastic bulkhead fitting to allow air to flow in as the reservoir level dropped. A high-efficiency particulate air (HEPA) filter was connected to the cap tubing to prevent air particles and bacteria from contaminating the sterile feedstock.

An additional hole was drilled on the container's shoulder and fitted with a 6.4mm bulkhead fitting. A 6.4-mm ID tube with a cap at the end was attached on the outside. In the inside of the digester, a 6.4-mm ID tube extended to approximately $7-\mathrm{cm}$ from the bottom of the container. This tube was used to collect feedstock samples for testing by attaching a syringe to the end of the tube (on the outside) and drawing out liquid.

Approximately three meters of tubing connected the reservoirs to the digesters through the pump heads. The residence time of the feedstock in the tubes ranged between 36 to 144 minutes for HRTs between $6-36$ hours. Although many procedures were performed to prevent bacterial contamination (see Section 3.3.2), visible bacterial growth would sometimes occur in the tubing lines between the feedstock reservoirs and digesters. 


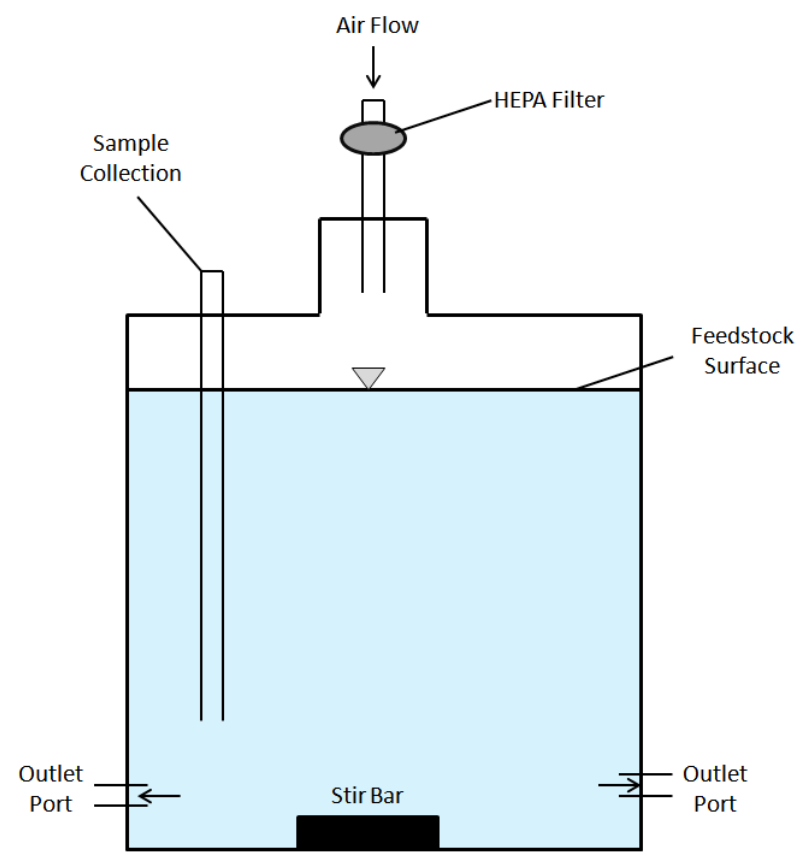

Figure 3-6: Schematic of a feedstock reservoir. The reservoirs were 20-L, continuouslymixed, and kept inside a refrigerator at $4^{\circ} \mathrm{C}$.

\subsubsection{Nitrogen Sparging Experiment Apparatus}

Additional equipment was used for $\mathrm{N}_{2}$ sparging experiments. Industrial-grade $\mathrm{N}_{2}$ from a pressurized cylinder was used. The pressure was set to 0.4 atm (6 PSI) for all sparging rates tested. Tubing of 6.4-mm diameter connected the gas cylinder regulator to the " $\mathrm{N}_{2} / \mathrm{CH}_{4}$ In" port of the digesters.

For high sparging flow rates (> $10 \mathrm{~L} \mathrm{~N} / \mathrm{L}-\mathrm{hr}$ ), rotameters (FM 1050 603, Matheson, Basking Ridge, NJ \& Gilmont, \& Gilmont Accucal GF-6541-1225, Cole-Parmer, Vernon Hills, IL) were used. These rotameters were calibrated using a primary flow meter (Drycal DC-2, Bios International, Butler, $\mathrm{NJ}$ ) to verify which rotameter reading attained the specified sparging rate at $6 \mathrm{PSI}$. 
During operation, the sparging rate calculated based on the daily volume measured by the gas meters was less than expected for high sparging flow rates. This was likely due to unnoticed leakages in the connection between the rotameter outlet fitting and tubing. Because testing high flow rates was one of the goals of this experiment, it was not essential for the expected sparging rate to match exactly with the calculated sparging rate.

At low flow rates (<10 L N $\mathrm{N}_{2} / \mathrm{L}-\mathrm{hr}$ ), a peristaltic pump (same model used for pumping liquid) was used to sparge gas into the digesters. The only low flow rate tested was $1 \mathrm{~L} / \mathrm{L}-\mathrm{hr}$, which was too small to be measured by the primary flow meter. Therefore, the hourly volume measured by the gas meters was used to verify the sparging rate was near $1 \mathrm{~L} / \mathrm{L}-\mathrm{hr}$.

\subsubsection{Feedstock Ingredients \& pH Control}

The refrigerated feedstock consisted of the following ingredients:

- Anhydrous D-glucose

- Autoclaved, anaerobic digester sludge

- Sodium phosphate dibasic heptahydrate $\left(\mathrm{Na}_{2} \mathrm{HPO}_{4} * 7 \mathrm{H}_{2} \mathrm{O}\right)$

- Potassium phosphate monobasic $\left(\mathrm{KH}_{2} \mathrm{PO}_{4}\right)$

Anhydrous D-glucose was added to the feedstock to attain the required glucose concentration for a specific OLR or HRT tested.

In a side-experiment (Section 4.2), autoclaved, anaerobic digester sludge collected from the City of San Luis Obispo (SLO) Water Resource Recovery Facility (WRRF) (same source as inoculum, described in Section 3.1.8), was 
found to be ideal for providing necessary nutrients to the bacteria, and it was added to the feedstock reservoirs at $1 \%$ (or $200 \mathrm{~mL}$ ) of the total feedstock volume (20 L).

The chemicals $\mathrm{Na}_{2} \mathrm{HPO}_{4^{*}} 7 \mathrm{H}_{2} \mathrm{O}$ and $\mathrm{KH}_{2} \mathrm{PO}_{4}$ were added separately to increase the buffering capacity of the first-phase digesters so that digester $\mathrm{pH}$ could be kept stable. The amount of phosphate buffers to be added was estimated based on pHs measured for previous experiments and the target $\mathrm{pH}$ for the current experiment. In general, the combined amount of buffers added ranged between $0.05-0.15 \mathrm{M}$.

For some experiments, $10-\mathrm{N}$ sodium hydroxide $(\mathrm{NaOH})$ was added in small quantities to raise the $\mathrm{pH}$ of the feedstocks above the logarithmic acid dissociation constant $\left(\mathrm{pK}_{\mathrm{a}}\right)$ of 7.2 for the phosphate buffers used. The $\mathrm{pK}_{\mathrm{a}}$ equation for the phosphate buffering system is shown below:

Equation 3-3: $\mathrm{pK}_{\mathrm{a}}$ equation

$$
\mathrm{pK}_{\mathrm{a}}=-\log \left[\frac{\left[\mathrm{H}^{+}\right]\left[\mathrm{HPO}_{4}^{-2}\right]}{\left[\mathrm{H}_{2} \mathrm{PO}_{4}-\right]}\right]
$$

At a pk of 7.2 , the ratios of $\left[\mathrm{HPO}_{4}^{-2}\right] /\left[\mathrm{H}_{2} \mathrm{PO}_{4}{ }^{-}\right]$are equal by definition, and $\mathrm{pH}=$ $\mathrm{pK}_{\mathrm{a}}$. Raising the $\mathrm{pH}$ of the feedstock above 7.2 increased the $\left[\mathrm{HPO}_{4}{ }^{-2}\right]$ and thus the acid buffering capacity of the feedstock because $\mathrm{HPO}_{4}{ }^{-2}$ could accept two protons $\left(\mathrm{H}^{+}\right)$whereas $\mathrm{H}_{2} \mathrm{PO}_{4}{ }^{-}$could only accept one.

No automated devices were used to control digester $\mathrm{pH}$, and the feedstock buffering system passively controlled the $\mathrm{pH}$ by limiting how low $\mathrm{pH}$ would drop. 
The feedstock could not regulate the digester $\mathrm{pH}$ completely, so the $\mathrm{pH}$ would increase or decrease while staying within \pm 0.20 of the average steady-state $\mathrm{pH}$. At higher glucose loading rates, it was expected more acid would be generated, lowering the $\mathrm{pH}$, so more buffer was added to counteract this effect (and vice versa).

\subsubsection{Digester Inoculum Source}

Digester inoculum sludge (bacterial seed) was taken from the unmixed, third digester in a series of three at the SLO WRRF, which treats municipal wastewater. The digested sludge was comprised of a mixture of primary clarifier sludge, trickling filter secondary clarifier sludge, and nitrifying activated sludge. All waste sludge from the clarifiers ( $75 \%$ of it being primary sludge) is thickened and then anaerobically digested in the three digesters with a combined solids residence time (SRT) of approximately 60 days. The sludge had an average VSS and COD of $17754 \pm 2919 \mathrm{mg} / \mathrm{L}$ and $27179 \pm 3539 \mathrm{mg} / \mathrm{L}$ during the oneyear duration of this project, respectively.

The seed sludge was screened and used to inoculate the digesters each time a new operating variable was tested. The digesters were cleaned before being reused, so the digesters were filled with $1-L$ fresh sludge to begin new experiments. It was assumed the bacterial population of San Luis Obispo's (SLO) anaerobic digesters did not change significantly over the duration of an experiment and therefore did not influence results despite the inoculum being collected at different times. SLO's anaerobic digesters have a relatively long SRT (60 days) and a fairly consistent feed of municipal sludge. 


\subsubsection{Serum Bottle Experiment Setup}

While the majority of experiments were continuous-flow, a serum bottle (batch) experiment was performed early in the project to understand why initial firstphase experiments had poor $\mathrm{H}_{2}$ yields and acidic $\mathrm{pH}(<5)$. Because these initial experiments did not use fresh inoculum to test new variables, the bacterial cultures were possibly debilitated. Some essential trace nutrient solutions may have also been missing (see Section 4.1 for description of issues). Thus, the serum bottle experiment was designed to test alternative trace nutrient solutions to increase $\mathrm{H}_{2}$ production and gauge bacterial population health compared to fresh sludge inoculum.

The methods and apparatus described below were used for conducting the serum bottle experiment.

First, glass serum bottles (165-mL total) were filled with different types and amounts of constituents (see Section 4.2.1 for serum bottle contents) to a liquid volume of $100-\mathrm{mL}$.

To make the serum bottles anaerobic at the start of the experiment, $\mathrm{N}_{2}$ was purged through the headspace of each bottle for one minute, and the bottles were capped with 20-mm polytetrafluoroethylene-faced butyl septa to allow for gas sampling. The serum bottles were placed in an incubator at $35 \pm 2^{\circ} \mathrm{C}$.

To measure gas production from the serum bottles, a $250-\mathrm{mL}$ graduated cylinder was filled with water. A hole was drilled into the closed end of a $100-\mathrm{mL}$ graduated cylinder and a 6.4-mm bulkhead tube fitting was attached. The 100- 
$\mathrm{mL}$ cylinder was inverted and placed into the larger cylinder. Tubing (6.4-mm) was connected to the bulkhead fitting and extended from the closed end of the inverted cylinder to a luer-to-barb fitting and needle. The needle was inserted into the septa of the serum bottle to be measured, which caused the smaller cylinder to fill with gas and rise up in the larger cylinder. Once the cylinder stopped rising, the gas volume displaced was recorded as gas production since the last purging operation (Figure 3-7).

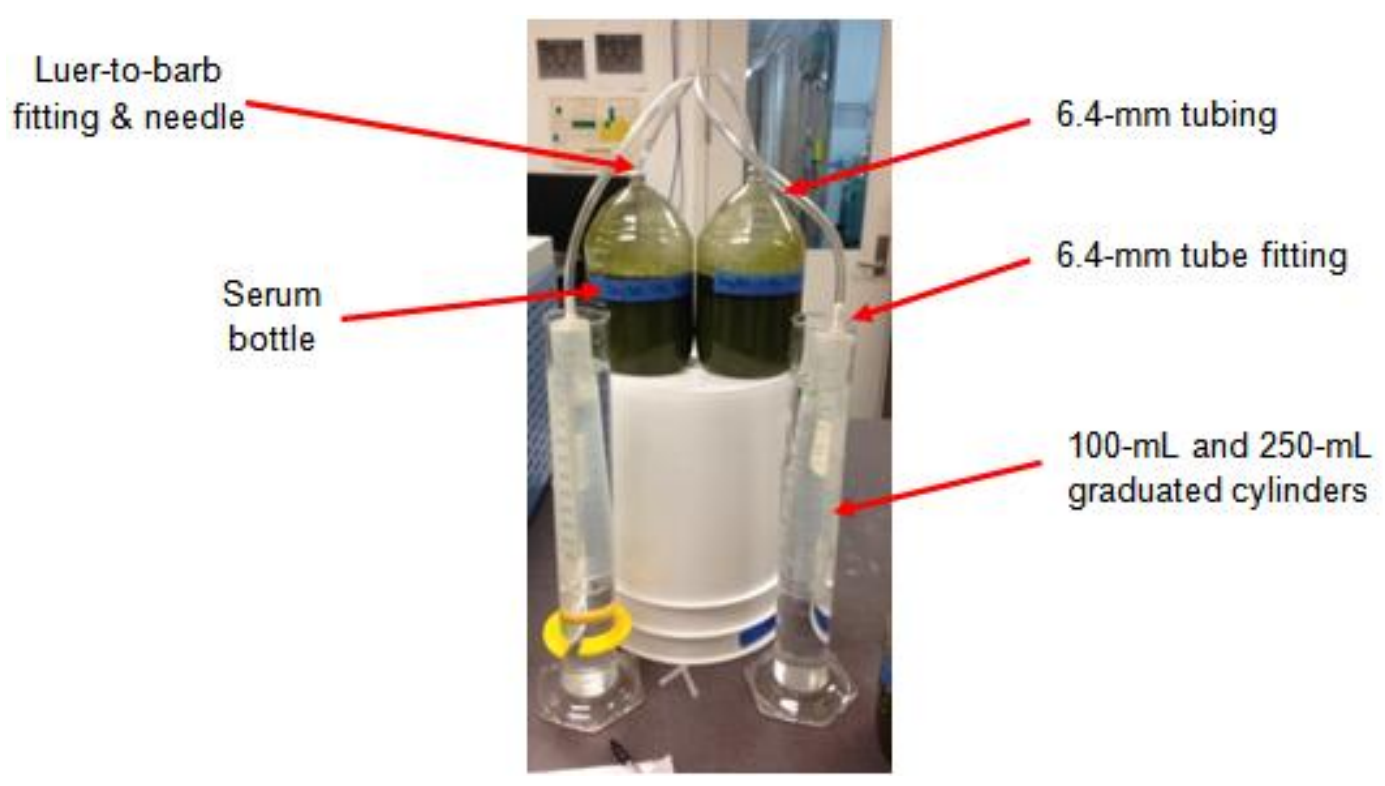

Figure 3-7: Experimental apparatus used for measuring biogas production from serum bottles (Hill, 2014). The serum bottles in this figure are from a different study using algae.

\subsection{Analytical Test Methods}

The following variables were measured for this project:

- Alkalinity: The buffering capacity of a liquid sample. Represented in units of $\mathrm{mg} \mathrm{CaCO} / \mathrm{L}$

- $p H$ : Measure of the $[\mathrm{H}+]$ concentration in a liquid sample. 
- Biogas Composition: For measuring $\% \mathrm{H}_{2}, \% \mathrm{CH}_{4}$, and $\% \mathrm{CO}_{2}$ in biogas.

- Chemical Oxygen Demand (COD): Indirect measurement of the amount of organic compounds in a wastewater sample.

- Total Suspended Solids (TSS): Measurement of the suspended matter in water.

- Volatile Suspended Solids (VSS): Measurement of the amount of suspended matter in a liquid sample that ignites at $550^{\circ} \mathrm{C}$ for 15 minutes.

- Glucose Concentration: Measurement of the soluble glucose concentration in a sample.

These analytical methods are described more fully in the following sections.

\subsection{1 $\mathrm{pH} \&$ Alkalinity}

Alkalinity and $\mathrm{pH}$ were determined using standard methods (APHA, 2005). $\mathrm{pH}$ was determined using a calibrated Oakton $\mathrm{pH}$ probe with a gel type electrode, and alkalinity was determined per Method 2320B by titrating with $0.02 \mathrm{~N}$ or 0.20 $\mathrm{N} \mathrm{H}_{2} \mathrm{SO}_{4}$ to $\mathrm{pH} 4.5$ (APHA 2005).

\subsubsection{Biogas Composition}

Biogas composition was determined using a gas chromatograph (Model 8610, SRI, Torrance, California) equipped with a concentric column (Alltech CTR I, Deerfield, Illinois) consisting of outer and inner columns measuring 6.4-mm and 3.2-mm ID, respectively. The inner column contained an activated molecular sieve and the outer column was filled with a porous polymer mixture. Ultra-high 
purity argon was used as the carrier gas. The gas chromatograph (GC) was operated at a temperature of $55^{\circ} \mathrm{C}$ and carrier gas flow rate of $16 \mathrm{~mL} / \mathrm{min}$. The GC was located in the same room as the digesters. Gas samples were collected by removing $1-\mathrm{mL}$ of biogas from the digester headspace and injecting the sample into the GC per the bench method (Lundquist Laboratory, 2014) The sample run time was 22 minutes as methane took the longest to peak.

\subsubsection{Chemical Oxygen Demand}

COD was tested using the closed reflux, colorimetric method (APHA, Method 5220D, 1997). Heating blocks (Orion COD165, Thermo Fisher Scientific, Waltham, MA, \& Model 163-486, Bioscience, Allentown, PA) and a colorimeter (Model DR/890, Hach, Colorado, USA) were used. All samples were digested using 0-1500 mg/L range COD reagent vials (CHEMetrics HR, Midland, Virginia). A majority of samples required dilution to be within the method range. The lower detection limit (LDL) of the COD vials was $100 \mathrm{mg} / \mathrm{L}$ with an error of $\pm 30 \%$ at this limit. For COD values between 500 - 1000 mg/L, which all diluted samples were within, the error was $\pm 7.5 \%$.

\subsubsection{Total and Volatile Suspended Solids}

TSS and VSS were measured following standard methods (APHA 2540D \& 2540E, 2005) using glass fiber filters (1.2- $\mu \mathrm{m}$ pore size, G4 Grade, Fisherbrand) and a vacuum pump (Model 1HAB-25B-M100X, GAST, Benton Harbor, Michigan). Filters were weighed with a four-point balance (Model AG245, Mettler Toledo). In general, at least $10-\mathrm{mL}$ of sample was needed to attain the minimum $2.5 \mathrm{mg}$ dry residue on the filters per APHA. 


\subsubsection{Glucose Concentration}

Glucose was measured using the "UV-method for Determination of D-glucose in Foodstuffs and Other Materials (R-Biopharm, 2015). A UV-VIS spectrophotometer (UV-1700 PharmaSpec, Shimadzu, Kyoto, Japan), set to read at a wavelength of $340 \mathrm{~nm}$, was used to measure the absorbance of samples.

The test's precision was $\pm 0.09 \mathrm{~g} / \mathrm{L}$ and $\pm 0.86 \mathrm{~g} / \mathrm{L}$ for samples with a dilution factor (DF) of 10 and 100, respectively (R-Biopharm, 2015).

For all experiments, the measured feedstock glucose concentration was less than expected based on the amount of glucose added to the container. A possible cause was bacterial contamination in the feedstock containers, which may have caused glucose to be consumed before entering the digesters. Also, water could contaminant the anhydrous-glucose container, resulting in faulty glucose measurements. Besides contamination, it is possible the samples degraded as glucose samples were not tested until 3-12 months after being collected and stored in the freezer (the glucose bench method was developed inhouse and was not finalized until near the end of the project).

To correct for this, GLR was calculated by dividing the average feedstock glucose concentration measured during the steady-state period by the HRT. The equation is expressed below:

Equation 3-4: GLR Correction Calculation

$$
\text { Calculated GLR }\left(\frac{\mathrm{g}}{\mathrm{L} \text {-day }}\right)=\frac{\text { Avg. Glucose Concentration }\left(\frac{\mathrm{g}}{\mathrm{L}}\right)}{\mathrm{HRT}(\mathrm{hr}) / 24}
$$




\subsubsection{Quality Control Procedures}

To ensure accuracy, splits and/or matrix spikes were performed for each

analytical test. Split samples passed quality control standards if the values were within $10 \%$ of each other (Equation 3-5).

\section{Equation 3-5: Split Percent Error Formula}

$$
\% \text { Error in Splits }=\frac{\mid(1 \mathrm{st} \text { Split Value })-(2 \mathrm{nd} \text { Split Value }) \mid}{\text { Smallest Split Value }} \times 100 \%
$$

For spiked samples, if the measured concentration was within 85 to $115 \%$ of the expected concentration, the sample passed (Equation 3-6).

$$
\begin{aligned}
& \text { Equation 3-6: Spike Percent Recovery Formula } \\
& \% \text { Recovery }=\frac{\text { Spike Value Measured }}{\text { Spike Value Expected }} \times 100 \%
\end{aligned}
$$

Some sample sets with bad splits or spikes were passed if the discrepancies could be sufficiently attributed to poor sampling or testing technique. Sample sets that did not meet quality control criteria for unknown reasons were retested until they passed or expired.

As an additional quality control measure, blanks and standard checks were performed for all analytical tests following their respective bench methods. 


\subsection{Operations \& Maintenance}

Once the digesters were running, daily maintenance tasks were performed to ensure they were operating correctly. The procedures used for operating, maintaining, and collecting data from the digesters are described below.

\subsubsection{Experiment Startup Procedure}

To begin experiments, two digesters (duplicates) were filled to $1-L$ with anaerobic digester sludge collected from the SLO WRRF on the same day. Afterward, the digesters were sealed, placed on a stir-plate, and set to $30^{\circ} \mathrm{C}$. Next, the inlet and outlet fittings were connected to pre-calibrated peristaltic pumps (calibration procedure described in Section 3.3.2). The pumps could not operate continuously at the low flow rates required. Therefore, an hourly pumping schedule was used, and the amount of liquid pumped in and out of the digesters every hour depended on the HRT.

The "gas out" line (Figure 3-3) was connected to a Tedlar bag and calibrated gas meter. 20-L of feedstock was prepared with anhydrous D-glucose depending on the glucose loading rate tested. The feedstock container was placed on a stirplate inside a refrigerator at $4^{\circ} \mathrm{C}$ and connected to the peristaltic pump. The inlet tubing lines were primed with feedstock before turning on the pumps to ensure no air would enter the digesters.

After all connections were complete and the inlet lines were primed, pressurized $\mathrm{N}_{2}$ (2-4 psi) was sparged through the " $\mathrm{N}_{2} / \mathrm{CH}_{4}$ In" port of the digester to make the head space anaerobic. After at least two minutes of sparging, the nitrogen 
cylinder was turned off and the " $\mathrm{N}_{2} / \mathrm{CH}_{4}$ port" was quickly sealed. Finally, the influent and effluent pumps were turned on and set to pump automatically.

\subsubsection{Daily Maintenance Tasks}

After setting up the digesters, the $\mathrm{pH}$, alkalinity, and gas production were monitored each day. Gas composition, TSS/VSS, COD, and glucose were not tested or collected until steady-state was reached (see Section 3.3.3 for explanation of steady-state).

Liquid samples for digestate and feedstock testing were collected using a syringe. Samples were placed in a beaker and promptly sealed with ParaFilm.

Gas production was measured by slowly squeezing the gas in the Tedlar bags into the gas meters. Squeezing the Tedlar bags usually took place exactly every 24 hours, but differences of $24 \pm 3$ hours would sometimes occur. To account for this difference, the daily gas production was normalized for the time interval.

Besides monitoring the health of the digesters, multiple maintenance tasks were performed each day to ensure the digesters were operating correctly. The most common tasks were:

1. Reducing bacterial contamination in the feedstock and inlet lines: The digester feed was never sterile due to the pervasiveness of bacteria. Consumption of glucose in the storage container and feed tube lines was minimized by bleaching the inlet lines periodically whenever bubbles appeared in the tubing. Additionally, the feedstock containers were 
cleaned with bleach and fitted with a new HEPA air filter each time they were replaced. All measuring equipment was with desanitized with isopropyl alcohol before being used to weigh and transfer chemicals.

2. Manually filling the digesters with feedstock or removing liquid from the digesters to ensure they were at a $1 \mathrm{~L}$ liquid volume: Because the amount of liquid pumped in and out of the digester were nearly impossible to make the same due to differences in tubing age, length, or pumphead wear, a net gain or loss of $\pm 200 \mathrm{~mL}$ digester volume occurred each day.

3. Refilling the temperature ports \& gas meters with water: The water in the temperature ports and gas meters would evaporate, so water was added to keep them filled at the correct level.

4. Ensuring digesters \& feedstock containers were stirring correctly: Stir bars would occasionally stop spinning. This was corrected by using a magnet to realign the stir bar with the stir plate. 


\subsubsection{Steady State Data Collection}

Alkalinity, $\mathrm{pH}$ and gas production were monitored daily to gauge whether the conditions inside the digester had reached steady state. Determining when steady-state was reached was important because the data collected during this period was representative of what would occur for a continuous, long-term operation of the system. The following criteria were used in determining when steady-state was reached:

- The difference between measured $\mathrm{pH}$ and alkalinity values on consecutive days was less than $20 \%$. Gas production was not considered because the gas meters only measured in $100 \mathrm{~mL}$ increments (per tip), and for digesters that produced little gas, the difference between one or two tips was very large.

- $p H$, alkalinity, or gas production were not following a distinct trend

- At least 3 HRTs had passed to ensure the first-phase digesters had selected for hydrogen-producing bacteria and washed out methanogens initially present in the inoculum

If the steady-state criteria above were met, gas composition, and TSS/VSS were tested in addition to $\mathrm{pH}$, alkalinity, and gas production for five days. COD and glucose samples were also preserved for future testing.

If one of the duplicate digesters did not meet steady-state criteria, data was still collected for both. Because each digester was subjected to the same conditions, they should have both produced similar results. In general, all measured values 
for duplicate digesters were within $\pm 20 \%$ of each other on a given day, with major differences being attributed to stirring problems, differences in liquid volume, or bacterial contamination in the feedstock inlet tubing.

TSS/VSS measurements of the first-phase digesters and feedstock were initially used to estimate suspended biomass in the digesters, but the VSS of the feedstock and digesters were usually too similar to each other to accurately calculate the biomass. For example, on some occasions, feedstock VSS was higher than digester VSS. Therefore, TSS/VSS data was not collected for most first-phase experiments.

\subsubsection{Experiment Shutdown Procedure}

Once five steady-state data points were collected, the pumps were turned off and the digesters, feedstock containers, and tubing were cleaned with bleach and rinsed with water. If a new experiment was conducted, the digesters were leakchecked before being reused.

\subsubsection{Steady-State Period Verification}

To confirm steady-state was reached, after an experiment the average percent hydrogen, $\mathrm{COD}$, and $\mathrm{pH}$ were calculated for a certain time period (3-5 days at steady state). If all values for each variable in that range were within $\pm 20 \%$ of the average, then these data were considered representative of the particular HRT, OLR, or sparging rate tested. Although alkalinity measurements were initially used to indicate whether the steady-state threshold was reached, alkalinity was not included in this check as there tended to be spikes or dips in alkalinity 
throughout steady-state despite the other variables remaining more stable.

Glucose was not used in this verification because the feedstock containers were sometimes switched out during steady-state and bacterial contamination varied throughout an experiment.

\subsubsection{Hydrogen Yield Analysis}

Most hydrogen fermentation studies calculate the glucose-consumption $\mathrm{H}_{2}$ yield (mol $\mathrm{H}_{2} / \mathrm{mol}_{\text {glucose }}$ consumed) and volumetric $\mathrm{H}_{2}$ yield $\left(\mathrm{L} \mathrm{H}_{2} / \mathrm{L}\right.$-day), but additional ways of calculating $\mathrm{H}_{2}$ yield are useful for truly understanding which operating variable values optimized hydrogen production (Table 3-1).

Table 3-1: Descriptions of the types of $\mathrm{H}_{2}$ yields analyzed for all $1^{\text {st }}$-phase optimization and $\mathrm{N}_{2}$ sparging experiments.

\begin{tabular}{|c|c|c|}
\hline Yield Name & Units & Description \\
\hline $\begin{array}{l}\text { Volumetric } \\
\mathrm{H}_{2} \text { Yield }\end{array}$ & $\begin{array}{l}\mathrm{L} \mathrm{H}_{2} / \\
\text { L-day }\end{array}$ & $\begin{array}{c}\text { Volume }(\mathrm{L}) \text { of } \mathrm{H}_{2} \text { produced at lab-room } \\
\text { conditions }\left(20^{\circ} \mathrm{C}, 1 \text { atm), normalized for }\right. \\
\text { digester liquid-volume (1-L) }\end{array}$ \\
\hline $\begin{array}{c}\text { Glucose-Introduced } \\
\mathrm{H}_{2} \text { Yield }\end{array}$ & $\begin{array}{c}\mathrm{mol} \mathrm{H}_{2} / \\
\text { mol glucose } \\
\text { introduced }\end{array}$ & $\begin{array}{l}\text { Amount of } \mathrm{H}_{2} \text { produced considering the } \\
\text { amount of glucose fed, or introduced, to } \\
\text { the bacteria }\end{array}$ \\
\hline $\begin{array}{l}\text { Glucose-Consumption } \\
\qquad \mathrm{H}_{2} \text { Yield }\end{array}$ & $\begin{array}{c}\mathrm{mol} \mathrm{H}_{2} / \\
\text { mol Glucose }\end{array}$ & $\begin{array}{l}\text { Amount of } \mathrm{H}_{2} \text { produced for every unit of } \\
\text { glucose consumed. Represents } \\
\text { glucose-utilization efficiency }\end{array}$ \\
\hline $\begin{array}{c}\text { COD-Introduced } \\
\mathrm{H}_{2} \text { Yield }\end{array}$ & $\begin{array}{c}\mathrm{mol} \mathrm{H}_{2} / \\
\text { mol } \mathrm{COD}_{\text {introduced }}\end{array}$ & $\begin{array}{c}\text { Amount of } \mathrm{H}_{2} \text { produced considering the } \\
\text { amount of } \mathrm{COD} \text { fed, or introduced, to } \\
\text { the bacteria }\end{array}$ \\
\hline $\begin{array}{c}\text { COD-Destroyed } \mathrm{H}_{2} \\
\text { Yield }\end{array}$ & $\begin{array}{c}\mathrm{mol} \mathrm{H}_{2} / \\
\text { mol } \mathrm{COD}_{\text {destroyed }}\end{array}$ & $\begin{array}{l}\text { Amount of } \mathrm{H}_{2} \text { produced for every unit of } \\
\text { COD destroyed. Represents substrate- } \\
\text { utilization efficiency }\end{array}$ \\
\hline
\end{tabular}


The glucose-introduced $\mathrm{H}_{2}$ yield ( $\mathrm{mol} \mathrm{H}_{2} / \mathrm{mol}_{\text {glucose }}$ introduced) is useful as it shows how well the bacteria produced $\mathrm{H}_{2}$ considering how much glucose they were fed.

Because COD was measured (and is more reliable than glucose data), the CODintroduced $\mathrm{H}_{2}$ yield ( $\mathrm{mol} \mathrm{H}_{2} / \mathrm{mol} \mathrm{COD}_{\text {introduced }}$ ) and COD-destroyed $\mathrm{H}_{2}$ yield (mol $\mathrm{H}_{2} / \mathrm{mol}^{\mathrm{CO}} \mathrm{D}_{\text {destroyed }}$ ) are also helpful. Note: "destroyed" is used instead of "consumed" because bacteria remove, or "destroy", soluble COD in the form of $\mathrm{H}_{2}$ or $\mathrm{CH}_{4}$ gas.

All of these yields are analyzed for first-phase optimization and $N_{2}$ sparging experiments.

\subsection{D Surface Modeling Procedures}

3D surface models of HRT vs. OLR vs. $\mathrm{H}_{2}$ yield were made to deduce which operating conditions maximized $\mathrm{H}_{2}$ yield based on the experimental data collected. The source of data came from first-phase optimization experiments that were operated within a $\mathrm{pH}$ range of $5.0-6.5$ (some variables were tested at $\mathrm{pH}<5.0$ and $\mathrm{pH}>6.5)$.

Data collected from first-phase optimization experiments were inputted into a surface-fitting program called TableCurve3D (Systat Software, San Jose, CA). The program generated up to 1000 3D surfaces along with a corresponding equation and $R^{2}$ value. The surface chosen was the one that matched the data as closely as possible and made logical sense (e.g at an HRT or OLR of zero, hydrogen yield should be zero). $\mathrm{H}_{2}$ yield values of zero were inputted at the 
following HRT and OLRs to establish boundary limits and to create more accurate models:

- (0-hr, 0 g COD/L-day)

- (0-hr, 15 g COD/L-day)

- (0-hr, 30 g COD/L-day)

- (15-hr, 0 g COD/L-day)

- (30-hr, 0 g COD/L-day) 


\section{CHAPTER 4: FIRST-PHASE OPTIMIZATION EXPERIMENTS}

First-phase optimization experiments were necessary to determine the ideal operating conditions (HRT, and OLR) for optimizing hydrogen production in the first-phase. The nitrogen sparging and integrated operation experiments could not begin without first optimizing this phase. Also, first-phase testing accounted for about $60 \%$ of the time spent on collecting data for this project. Therefore, the first-phase experiments are discussed in this chapter while the other experiments are discussed in Chapter 5.

The procedures and results for all first-phase experiments are discussed below.

\subsection{Issues with Initial First-Phase Experiments}

The first-phase digesters were initially operated at varying HRTs and a constant organic loading rate of $6 \mathrm{~g}$ glucose/L-day to determine the ideal operating conditions for producing $\mathrm{H}_{2}$. No particular $\mathrm{pH}$ operating range was used (ranged between $\mathrm{pH} 4-7$ ) because it was not clear where the ideal $\mathrm{pH}$ range was at the time.

Initial first-phase experiments had volumetric hydrogen yields between 0.01 $0.47 \mathrm{~L} \mathrm{H}_{2} / \mathrm{L}$-day, which were extremely low. The following major operational differences possibly contributed to this problem:

- Open feedstock containers: 18.9-L (five gallon) open buckets were originally used to hold the feedstock instead of 20-L, capped Nalgene containers. The buckets were mixed using a stir bar and stir plate, but the stir bars tended to stop spinning and needed to be repositioned by hand to 
spin again. Readjusting the stir bar by hand could introduce bacterial contamination into the feedstock, potentially causing glucose to be consumed before it reached the digesters.

- Low buffering capacity feedstock: A feedstock solution containing $1.0 \mathrm{~g} / \mathrm{L}$ yeast extract, $0.5 \mathrm{~g} / \mathrm{L}$ peptone, $0.5 \mathrm{~g} / \mathrm{L}$ meat extract, $3.2 \mathrm{~g} / \mathrm{L}$ $\mathrm{Na}_{2} \mathrm{HPO}_{4} 7 \mathrm{H}_{2} \mathrm{O}, 1.5 \mathrm{~g} / \mathrm{L} \mathrm{KH}_{2} \mathrm{PO}_{4}$, glucose, and 18-L tap water was fed to the digesters. The glucose concentration was adjusted based on the HRT tested. This feedstock was picked because the same chemicals were used for a similar two-phase digestion project using 2-L working volume digesters and a short HRT to produce $\mathrm{H}_{2}$ (Cooney et al., 2007). The major problem with this feedstock was within a few days of preparing a new batch, the feedstock would lose all of its alkalinity and the $\mathrm{pH}$ would drop to less than 5 quickly. This was likely due to bacterial contamination, since bacteria produce acids as byproducts while consuming glucose.

- Acidic digesters: The $\mathrm{pH}$ in the digesters were very acidic (less than $\mathrm{pH} 5$ ) as a result of the feedstock's poor buffering capacity and low $\mathrm{pH}$.

- Abrupt changes in HRT without reseeding: The HRT was changed abruptly without cleaning the digesters or reseeding. The sudden change in HRT potentially "shocked" the bacteria and resulted in poor performance. 
- Steady-state collection period: Because the HRT tended to be changed on a Friday, for convenience it was assumed the digesters were at steadystate by the following Monday, even if this was not true.

- Digesters were not sealed or leak tested: Caulking was not applied around the digester fittings, and digesters were never leak tested. Biogas may have leaked out of the digesters.

As a result of these issues, a serum bottle experiment was conducted to determine if better feedstock nutrients could be provided to increase $\mathrm{H}_{2}$ yields, and to troubleshoot low $\mathrm{H}_{2}$ yields.

\subsection{Serum Bottle Experiment}

The procedures, setup, and results of the serum bottle experiment, which was designed to address and resolve initial first-phase experiment issues, are discussed in this section.

\subsubsection{Experimental Procedures}

Eight sets of serum bottles (22 bottles total), each filled to $100-\mathrm{mL}$, were prepared for this experiment following the setup in Table 4-1.

The initial $\mathrm{pH}$ and alkalinity were tested before purging with $\mathrm{N}_{2}$ and sealing each bottle. Afterward, biogas composition and volume were tested each day until biogas production ceased. At the end of the experiment, the serum bottles were opened and tested for $\mathrm{pH}$ and alkalinity. 
Each serum bottle set in Table 4-1 contained different types and amounts of inoculum (seed), substrate (feed), and nutrients. "Autoclaved Digester-3 Sludge" consisted of anaerobic digester sludge collected from the third digester at the SLO WRRF, which was autoclaved at $250^{\circ} \mathrm{F}$ and 20 psig for 30 minutes. Autoclaved sludge was chosen as a possible nutrient source because it came from a healthy anaerobic digester and likely contained all the essential nutrients for bacterial growth. Autoclaving was required to ensure the sludge did not reseed the digesters or contaminate the feedstock. "Semidefined media" was the feedstock originally used for first-phase experiments. "Old seed" was made up of all the liquor from each digester used in initial first-phase experiments mixed together. Bold's Basal Media was tested as another possible defined media. It was a medium designed for algae that was thought to be acceptable for bacteria.

Some sets contained glucose to determine hydrogen production. Sets without glucose served as controls to compare with glucose-fed sets. 
Table 4-1: Setup used for the Serum Bottle Experiment to aid in determining which feedstock nutrient solution was ideal, and to troubleshoot why the initial first-phase experiments had low yields. Each serum bottle (165-mL capacity) had a total of $100-\mathrm{mL}$ liquid volume.

\begin{tabular}{|c|c|c|c|c|c|}
\hline $\begin{array}{c}\text { Set } \\
\#\end{array}$ & $\begin{array}{l}\text { Description of } \\
\text { Set Tested }\end{array}$ & $\begin{array}{c}\text { \# of } \\
\text { Bottles }\end{array}$ & Seed & Feed & Nutrients \\
\hline 0 & $\begin{array}{l}\text { Autoclaved } \\
\text { Digester } 3 \\
\text { Only }\end{array}$ & 1 & None & None & $\begin{array}{c}100-\mathrm{mL} \\
\text { Autoclaved } \\
\text { Digester } 3 \text { Sludge }\end{array}$ \\
\hline 1 & Old Seed Only & 2 & $\begin{array}{l}100-m L \\
\text { Old Seed }\end{array}$ & None & None \\
\hline 2 & $\begin{array}{c}\text { Old Seed + Glucose } \\
\text { + Semidefined } \\
\text { Media }\end{array}$ & 3 & $\begin{array}{l}\text { 20-mL Old } \\
\text { Seed }\end{array}$ & $\begin{array}{l}\text { Media } \\
\text { Contained } \\
\text { Glucose } \\
(6 \mathrm{~g} / \mathrm{L})\end{array}$ & $\begin{array}{l}80-\mathrm{mL} \\
\text { Semidefined } \\
\text { Media }\end{array}$ \\
\hline 3 & $\begin{array}{c}\text { Old Seed + Glucose } \\
+ \text { Bold's Basal } \\
\text { Media }\end{array}$ & 3 & $\begin{array}{l}\text { 20-mL Old } \\
\text { Seed }\end{array}$ & $\begin{array}{l}\text { Media } \\
\text { Contained } \\
\text { Glucose } \\
(6 \mathrm{~g} / \mathrm{L})\end{array}$ & $\begin{array}{l}\text { 80-mL Bold's } \\
\text { Basal Media }\end{array}$ \\
\hline 4 & $\begin{array}{c}\text { Old Seed + } \\
\text { Autoclaved Sludge }\end{array}$ & 2 & $\begin{array}{l}\text { 20-mL Old } \\
\text { Seed }\end{array}$ & None & $\begin{array}{c}\text { 17-mL Autoclaved } \\
\text { Digester } 3 \text { Sludge } \\
\text { \& 63-mL Deionized } \\
\text { Water }\end{array}$ \\
\hline 5 & $\begin{array}{l}\text { Old Seed + Bold's } \\
\text { Basal Media }\end{array}$ & 2 & $\begin{array}{l}\text { 20-mL Old } \\
\text { Seed }\end{array}$ & None & $\begin{array}{l}\text { 80-mL } \\
\text { Semidefined } \\
\text { Media }\end{array}$ \\
\hline 6 & $\begin{array}{l}\text { Old Seed + } \\
\text { Semidefined Media }\end{array}$ & 3 & $\begin{array}{l}\text { 20-mL Old } \\
\text { Seed }\end{array}$ & None & $\begin{array}{l}\text { 80-mL } \\
\text { Semidefined } \\
\text { Media }\end{array}$ \\
\hline 7 & $\begin{array}{c}\text { Old Seed + Glucose } \\
+ \text { Autoclaved } \\
\text { Digester } 3 \text { Sludge }\end{array}$ & 3 & $\begin{array}{l}\text { 20-mL Old } \\
\text { Seed }\end{array}$ & $\begin{array}{l}75-\mathrm{mL} \text { of } \\
\text { Glucose } \\
\text { Solution } \\
(6 \mathrm{~g} / \mathrm{L})\end{array}$ & $\begin{array}{l}5-\mathrm{mL} \text { Autoclaved } \\
\text { Digester } 3 \text { Sludge }\end{array}$ \\
\hline 8 & $\begin{array}{c}\text { Digester } 3 \text { Sludge + } \\
\text { Glucose }\end{array}$ & 3 & $\begin{array}{l}\text { 7-mL } \\
\text { Digester } 3 \\
\text { Sludge }\end{array}$ & $\begin{array}{l}\text { 93-mL of } \\
\text { Glucose } \\
\text { Solution } \\
(6 \mathrm{~g} / \mathrm{L})\end{array}$ & $\begin{array}{c}\text { Digester } 3 \text { Sludge } \\
\text { Inoculum Provided } \\
\text { Nutrients }\end{array}$ \\
\hline
\end{tabular}




\subsubsection{Results}

After eight days of testing gas production and composition, the serum bottles were re-opened and tested for their ending $\mathrm{pH}$ and alkalinity. All serum bottles experienced a decrease or stayed the same in $\mathrm{pH}$, with the exception of Set 5 (Bold's Basal Media + Old Seed) which increased in pH from 5.76 to 6.34.

Alkalinity decreased for all sets that produced $\mathrm{H}_{2}$, likely as a result of VFA production (Table 4-2).

Only two serum bottle sets produced significant amounts of $\mathrm{H}_{2}$. Each bottle from Set 7 (old seed, glucose, and autoclaved D3 sludge) and Set 8 (D3 Sludge + glucose) produced an average of 266.0 and $765.3 \mathrm{~mL} \mathrm{H}$ per $\mathrm{L}$ (Table 4-2). By Day 5, the cumulative amount of $\mathrm{H}_{2}$ produced in Sets 7 and 8 stayed constant until the experiment ended on Day 8 (Figure 4-1). 
Table 4-2: $\mathrm{pH}$, Alkalinity, and $\mathrm{H}_{2}$ production results for the Serum Bottle Experiment.

This experiment lasted eight days.

\begin{tabular}{|c|c|c|c|c|c|c|}
\hline \multirow{2}{*}{ \# } & \multirow{2}{*}{$\begin{array}{c}\text { Description } \\
\text { of Set } \\
\text { Tested }\end{array}$} & \multicolumn{2}{|c|}{$\mathrm{pH}$} & \multicolumn{2}{|c|}{$\begin{array}{c}\text { Alkalinity } \\
\left(\mathrm{mg} \mathrm{CaCO}_{3} / \mathrm{L}\right)\end{array}$} & \multirow{2}{*}{$\begin{array}{c}\begin{array}{c}\text { Total } \mathrm{H}_{2} \\
\text { Produced } \\
\left(\mathrm{mL} \mathrm{H}_{2}\right)\end{array} \\
\text { End }\end{array}$} \\
\hline & & Start & End & Start & End & \\
\hline 0 & $\begin{array}{c}\text { Autoclaved } \\
\text { D3 Sludge } \\
\text { Only }\end{array}$ & 9.51 & 9.38 & 787 & 4700 & 0.0 \\
\hline 1 & $\begin{array}{l}\text { Old Seed } \\
\text { Only }\end{array}$ & 6.09 & 6.09 & 1067 & 960 & 0.0 \\
\hline 2 & $\begin{array}{l}\text { Old Seed + } \\
\text { Glucose + } \\
\text { Semidefined } \\
\text { Media }\end{array}$ & 6.81 & 3.58 & 832 & 0 & 0.4 \\
\hline 3 & $\begin{array}{l}\text { Old Seed + } \\
\text { Glucose + } \\
\text { Bold's Basal } \\
\text { Media }\end{array}$ & 5.80 & 4.75 & 220 & 33 & 0.0 \\
\hline 4 & $\begin{array}{l}\text { Old Seed + } \\
\text { Autoclaved } \\
\text { Sludge }\end{array}$ & 8.38 & 7.62 & 920 & 970 & 0.0 \\
\hline 5 & $\begin{array}{c}\text { Old Seed + } \\
\text { Bold's Basal } \\
\text { Media }\end{array}$ & 5.76 & 6.34 & 210 & 467 & 0.0 \\
\hline 6 & $\begin{array}{c}\text { Old Seed + } \\
\text { Semidefined } \\
\text { Media }\end{array}$ & 6.81 & 6.60 & 800 & 1380 & 0.0 \\
\hline 7 & $\begin{array}{l}\text { Old Seed + } \\
\text { Gluc. + } \\
\text { Autocl. D3 } \\
\text { Sludge }\end{array}$ & 6.97 & 3.19 & 400 & 0 & 26.6 \\
\hline 8 & $\begin{array}{l}\text { Digester } 3 \\
\text { Sludge + } \\
\text { Glucose }\end{array}$ & 8.10 & 4.56 & 655 & 56 & 76.5 \\
\hline
\end{tabular}



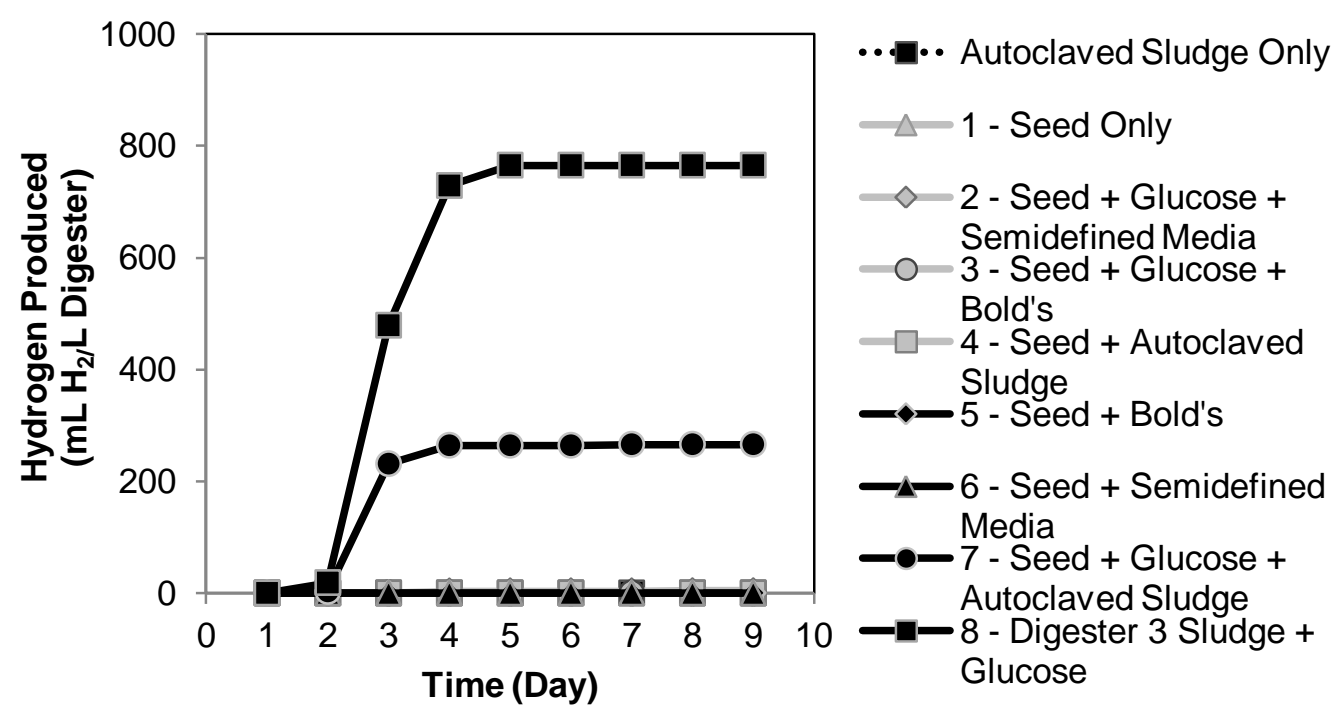

Figure 4-1: Cumulative hydrogen produced per for each serum bottle set. Note: Only Set 8 and Set 7 produced significant amounts of hydrogen in this experiment.

\subsubsection{Discussion}

The following sets were compared to troubleshoot problems with initial firstphase experiments:

- Set 8 vs. all other sets: If Set 8 (only set with Digester 3 as inoculum) had a significantly higher hydrogen yield than all other bottles, it was likely the old seed was of poor quality due to abruptly changing the HRT without reseeding.

- Set 7, Set 3, Set 2: Comparing these sets against each other indicated if essential nutrients were missing in either of the tested feedstocks.

- Set 2 vs. Set 6: Set 6 and Set 2 both consisted of seed and glucose, but Set 6 excluded semi-defined media. This comparison showed if the 
peptone, yeast extract, and meat extract from semi-defined media contributed to organic loading and, therefore, $\mathrm{H}_{2}$ yields.

- Set 0 : This set contained a single bottle filled with autoclaved digester sludge only. The purpose of this was to prove autoclaved sludge would not contaminate the feedstock or re-inoculate the digesters if it was used as a nutrient source.

The main measure of comparison for all bottles was the volumetric $\mathrm{H}_{2}$ yield per liter of serum bottle volume. This comparison was acceptable as all bottles in each set were filled with identical ingredients and volume.

The following observations were made for this experiment:

- The feedstock used in initial experiments lacked essential nutrients: Set 7 (autoclaved sludge as nutrient) had significantly higher $\mathrm{H}_{2}$ than Sets 3 and 2. Thus, it was concluded autoclaved sludge contained essential nutrients that Bold's Basal Media (Set 3) and semi-defined media (Set 2) were lacking.

- The seed was of poor quality: Set 8 , the only bottle that did not have old bacterial seed as the inoculum, had a significantly higher $\mathrm{H}_{2}$ yield (at least $300 \%$ higher) than all other bottles.

- Organic carbon from peptone, yeast extract, and meat extract did not contribute significantly to yields: $\mathrm{No}_{2}$ production was observed for Set 6 
(semi-defined media without glucose) throughout the entire experiment.

Meanwhile, Set 2, which contained semi-defined media and glucose, produced small amounts of $\mathrm{H}_{2}$.

- Autoclaved wastewater sludge did not contribute to seeding or contaminate the feedstock because it was sterile: No biogas was made for the serum bottle containing autoclaved sludge only (Set 0 ). This was expected because the sludge was sterilized by autoclaving. This is important because the feedstock would not be contaminated if autoclaved sludge was used as the nutrient source. Also, the first-phase digesters would not be re-inoculated if autoclaved sludge was present in the feedstock.

\subsubsection{Adjustments to Future Experiments}

This experiment showed the first-phase digesters were not operated properly at the time. For future first-phase experiments, the following adjustments were made (these are detailed more fully in Chapter 3 - Materials \& Methods):

- Ensure the digesters are properly sealed to prevent any possible leaks

- Use autoclaved sludge as the main nutrient provider in the feedstock

- Continue using $\mathrm{Na}_{2} \mathrm{HPO}_{4} \cdot 7 \mathrm{H}_{2} \mathrm{O}$ and $\mathrm{KH}_{2} \mathrm{PO}_{4}$ as buffering agents: Buffers are used to resist changes in $\mathrm{pH}$ when acid is created in the digesters, and having enough buffer was essential to ensuring the $\mathrm{pH}$ did not become too acidic (below pH 5). 
- Use fresh sludge from the SLO Wastewater Reclamation Facility to inoculate the digesters when changing experiment conditions: Because numerous experiments would be conducted, it was important to use an inoculum that had a relatively constant culture of bacteria so that all experiments started on the same basis. For this reason, Digester 3 Sludge was used to inoculate future experiments.

\subsection{Organic Loading Rate (OLR) Testing Experiment}

This experiment was conducted to determine which glucose loading rate (GLR), and eventually, organic loading rate (OLR), maximized hydrogen yields at a constant 12-hr HRT. The results of this experiment are analyzed and discussed in the sections below.

\subsubsection{Organic Loading Rate Correction}

Target GLRs ranging from 4 to $30 \mathrm{~g} \mathrm{C}_{6} \mathrm{H}_{12} \mathrm{O}_{6} / \mathrm{L}$-day were tested at a constant HRT of 12 hours. However, measured glucose concentrations did not agree closely with the glucose expected from back-calculating with COD data (Table 4-3). Also, the calculated GLRs (from glucose data) typically did not correspond with the target GLRs (Table 4-3).

This indicated that GLR was not a reliable measure for determining which loading rate optimized hydrogen yields.

Because of these issues, the OLR (in g COD/L-day) was a better measure to use than GLR. The COD test was more established than the glucose test, COD 
samples were tested a week after being collected as opposed to glucose samples being tested months after collection, and more samples were tested for COD with less deviation. Thus, the OLR (in g COD/L-day) was calculated from feedstock COD data (Table 4-3 - rightmost column) and was used to analyze hydrogen yields instead. Note: Because the steady-state $\mathrm{pH}$ range could not be completely controlled (described in Section 3.1.5), average pHs ranged from $4.39-6.50$.

Table 4-3: Feedstock glucose concentrations, COD concentrations, and calculated GLRs for all target GLRs and pHs tested. The feedstock glucose concentration expected based on COD measurements and the organic loading rate (OLR) in terms of COD were also calculated.

\begin{tabular}{|c|c|c|c|c|c|c|}
\hline $\begin{array}{c}\text { Target } \\
\text { GLR } \\
\left(\mathrm{g} \mathrm{C}_{6} \mathrm{H}_{12} \mathrm{O}_{6}\right. \\
/ \text { L-day) }\end{array}$ & $\mathrm{pH}$ & $\begin{array}{c}\text { Feedstock } \\
\text { Glucose } \\
\text { Measured } \\
(\mathrm{g} / \mathrm{L})\end{array}$ & $\begin{array}{c}\text { Calculated } \\
\text { GLR }^{2} \\
\left(\mathrm{~g} \mathrm{C}_{6} \mathrm{H}_{12} \mathrm{O}_{6}\right. \\
\text { /L-day) }\end{array}$ & $\begin{array}{c}\text { Feedstock } \\
\text { COD } \\
\text { Measured } \\
(\mathrm{mg} / \mathrm{L})\end{array}$ & $\begin{array}{c}\text { Feedstock } \\
\text { Glucose } \\
\text { Calculated } \\
\text { Based on } \\
\operatorname{COD}^{3}(\mathrm{~g} / \mathrm{L})\end{array}$ & $\begin{array}{c}\text { Calculated } \\
\text { OLR }^{4} \\
\text { (g COD/ } \\
\text { L-day) }\end{array}$ \\
\hline 4 & 5.77 & 2.34 & 4.7 & 2298.1 & 3.2 & 4.6 \\
\hline 6 & 4.39 & 2.98 & 6.0 & 3647.8 & 3.6 & 7.3 \\
\hline 6 & 6.14 & 2.07 & 4.1 & 3701.9 & 3.2 & 7.4 \\
\hline 8 & 4.87 & 1.94 & 3.9 & 4066.3 & 1.9 & 8.1 \\
\hline 12 & 4.24 & 4.78 & 9.6 & 6451.2 & 5.8 & 12.9 \\
\hline 12 & 5.87 & 5.14 & 10.3 & 6931.0 & 6.2 & 13.9 \\
\hline 14 & 5.94 & 5.51 & 11.0 & 7301.5 & 6.6 & 14.6 \\
\hline 16 & 4.25 & 7.60 & 15.2 & 8344.8 & 8.1 & 16.7 \\
\hline 16 & 5.83 & 6.65 & 13.3 & 8863.0 & 7.6 & 17.7 \\
\hline 23 & 6.11 & 8.98 & 18.0 & 11470.3 & 10.5 & 22.9 \\
\hline 30 & 6.37 & 12.14 & 24.3 & 15405.3 & 14.2 & 30.8 \\
\hline
\end{tabular}

${ }^{2}$ Calculated GLR $=($ Feedstock Glucose Measured $) /\left(12 \mathrm{hr} \mathrm{HRT} \times \frac{1 \text { day }}{24 \mathrm{hr}}\right)$

${ }^{3}$ Calculated by subtracting out $1 \%$ of the autoclaved sludge COD $(0.01 \times 27179.2 \mathrm{mg} / \mathrm{L})$ from the feedstock COD (because 200-mL autoclaved sludge was present in the 20-L feedstock reservoirs, or $1 \%$ ) and converting this number to g glucose/L (1.067 grams of COD per gram of glucose

${ }^{4}$ Calculated OLR $=\left(\right.$ Feedstock COD Measured $\left.\times \frac{1 \mathrm{~g} \mathrm{COD}}{1000 \mathrm{mg} \mathrm{COD}}\right) /\left(12 \mathrm{hr} \mathrm{HRT} \times \frac{1 \text { day }}{24 \mathrm{hr}}\right)$ 
4.3.2 Graphing of OLRs within $\mathrm{pH} 5.0-6.5$

The $1^{\text {st }}$-phase digesters were unintentionally operated above and below $\mathrm{pH} 5.0$ for this experiment (Table 4-3 $-2^{\text {nd }}$ column). This occurred because the steadystate $\mathrm{pH}$ range could not be completely controlled (described in Section 3.1.5). Because $\mathrm{pH} 5.0-6.5$ is typically considered optimal for hydrogen production, (J. Wang \& Wan, 2009) and is more practical for real-life applications (very acidic first-phase effluent could upset the second-phase digesters), only OLRs tested within this $\mathrm{pH}$ range are graphed. The data obtained for OLRs at $\mathrm{pH}<5.0$ are not graphed, but are still presented and discussed.

\subsubsection{Volumetric Hydrogen Yields \& Hydrogen Composition}

For OLRs operated at $\mathrm{pH}>5.0$, volumetric $\mathrm{H}_{2}$ yields were zero at tested OLRs of 4.6 and $7.4 \mathrm{~g} \mathrm{COD/L-day.} \mathrm{After} 7.4 \mathrm{~g}$ COD/L-day, as OLR increased, volumetric yields increased almost linearly to a peak of $1.02 \pm 0.13 \mathrm{~L} \mathrm{H}_{2} / \mathrm{L}$-day at $22.9 \mathrm{~g}$ $\mathrm{COD} / \mathrm{L}$-day. After this point, the volumetric yield dropped to $0.77 \pm 0.11 \mathrm{~L} \mathrm{H}_{2} / \mathrm{L}$ day at an OLR of $30.8 \mathrm{~g}$ COD/L-day (Table 4-4 \& Figure 4-2).

At low OLRs of 7.3 and $8.1 \mathrm{~g} \mathrm{COD/L-day} \mathrm{operated} \mathrm{at} \mathrm{pH}<5.0$, significantly more hydrogen was produced than similar OLRs (4.6 and $7.3 \mathrm{~g} \mathrm{COD/L-day)} \mathrm{operated}$ at $\mathrm{pH}>5.0$, which produced no biogas at all (Table 4-4).

The biogas $\mathrm{H}_{2}$ composition at all OLRs except $4.6 \mathrm{~g}$ COD/L-day was between 40 $-70 \% \mathrm{H}_{2}$. At 4.6 and $7.4 \mathrm{~g} \mathrm{COD/L-day,} \mathrm{no} \mathrm{biogas} \mathrm{production} \mathrm{occurred,} \mathrm{but}$ $43.0 \%$ and $6.2 \% \mathrm{H}_{2}$ were still measured, respectively (Table 4-4). 
Table 4-4: Volumetric $\mathrm{H}_{2}$ yields, and $\mathrm{H}_{2}$ composition measured for all organic loading rates and pHs tested at a constant 12-hr hydraulic residence time (HRT).

\begin{tabular}{cccc}
\hline $\begin{array}{c}\text { OLR } \\
\text { (g COD/L-day) }\end{array}$ & pH & $\begin{array}{c}\text { Percent } \\
\mathbf{H}_{2}(\%)\end{array}$ & $\begin{array}{c}\text { Vol. } \mathrm{H}_{2} \text { Yield } \\
\left(\mathbf{L} \mathrm{H}_{2} / \mathrm{L}-\text { day }\right)\end{array}$ \\
\hline 4.6 & 5.77 & 6.2 & 0.00 \\
7.3 & 4.39 & 55.1 & $0.24 \pm 0.03$ \\
7.4 & 6.14 & 43.0 & 0.00 \\
8.1 & 4.87 & 52.2 & $0.44 \pm 0.11$ \\
12.9 & 4.24 & 52.9 & $0.32 \pm 0.05$ \\
13.9 & 5.87 & 50.5 & $0.45 \pm 0.15$ \\
14.6 & 5.94 & 57.0 & $0.42 \pm 0.07$ \\
16.7 & 4.25 & 49.2 & $0.30 \pm 0.07$ \\
17.7 & 5.83 & 55.4 & $0.76 \pm 0.14$ \\
22.9 & 6.11 & 64.7 & $1.02 \pm 0.13$ \\
30.8 & 6.37 & 67.0 & $0.77 \pm 0.11$ \\
\hline
\end{tabular}

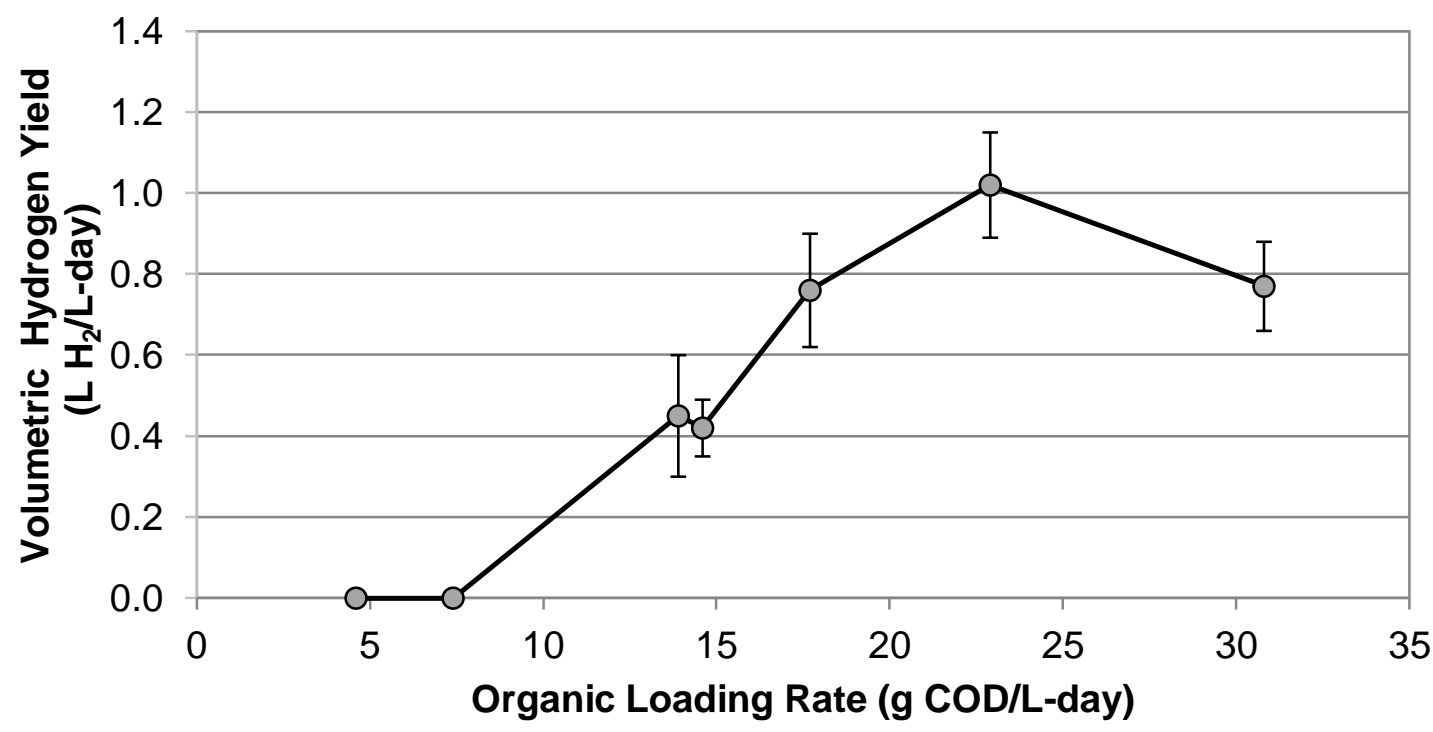

Figure 4-2: Volumetric $\mathrm{H}_{2}$ yields measured for all organic loading rates (OLRs) tested at a constant hydraulic residence time (HRT) of $12 \mathrm{hrs}$. Only OLRs operated between $\mathrm{pH}$ $5.0-6.5$ are graphed.

\subsubsection{Glucose Consumption}

Glucose consumption was calculated from influent (feedstock) glucose and effluent glucose concentrations (Table 4-5). Although glucose results may not have been accurate, glucose test results are still reported because digester 
performance correlates with the amount of glucose introduced and utilized by bacteria. For OLRs operated at $\mathrm{pH}>5.0$, glucose consumption dropped almost linearly from $95.1 \%$ at $4.6 \mathrm{~g} \mathrm{COD/L-day} \mathrm{to} 45.0 \%$ at $30.8 \mathrm{~g} \mathrm{COD/L-day} \mathrm{(Figure}$ 4-3 - dashed line). Note: At the 4.6 and $7.4 \mathrm{~g}$ COD/L-day loading rates, less feedstock glucose measurements were taken because it was apparent these OLRs were not producing gas.

While percent glucose consumption decreased starting from the lowest OLR of 4.6 $\mathrm{g} \mathrm{COD/L-day} \mathrm{tested,} \mathrm{the} \mathrm{amount} \mathrm{of} \mathrm{glucose} \mathrm{consumed} \mathrm{(in} \mathrm{g} / \mathrm{L}$ ) increased from $1.98 \mathrm{~g} / \mathrm{L}$ at $7.4 \mathrm{~g} \mathrm{COD} / \mathrm{L}$-day to $6.19 \mathrm{~g} / \mathrm{L}$ at $22.9 \mathrm{~g} \mathrm{COD} / \mathrm{L}$-day. At $30.8 \mathrm{~g}$ COD/L-day, the amount of glucose consumed decreased to $5.46 \mathrm{~g} / \mathrm{L}$ (Figure 4-3 - solid line).

Table 4-5: Influent (feedstock) glucose, effluent glucose, glucose consumed, and \% glucose consumption at all organic loading rates (OLRs) tested at a constant 12-hr hydraulic residence time (HRT).

\begin{tabular}{cccccc}
\hline $\begin{array}{c}\text { OLR } \\
(\mathbf{g} \text { COD/L- } \\
\text { day) }\end{array}$ & pH & $\begin{array}{c}\text { Influent } \\
\text { Glucose } \\
(\mathbf{g} / \mathbf{L})\end{array}$ & $\begin{array}{c}\text { Effluent } \\
\text { Glucose } \\
(\mathbf{g} / \mathbf{L})\end{array}$ & $\begin{array}{c}\text { Glucose }^{\text {Consumed }} \\
(\mathbf{g} / \mathbf{L})\end{array}$ & $\begin{array}{c}\text { \% Glucose } \\
\text { Consumed }\end{array}$ \\
\hline 4.6 & 5.77 & $2.34^{5}$ & $0.12 \pm 0.18$ & 2.23 & 95.1 \\
7.3 & 4.39 & $2.98 \pm 0.05$ & $0.14 \pm 0.12$ & 2.84 & 95.2 \\
7.4 & 6.14 & $2.07^{5}$ & $0.09 \pm 0.13$ & 1.98 & 95.8 \\
8.1 & 4.87 & $1.94 \pm 0.35$ & $0.48 \pm 0.38$ & 1.46 & 75.5 \\
12.9 & 4.24 & $4.78 \pm 0.52$ & $2.05 \pm 0.44$ & 2.73 & 57.1 \\
13.9 & 5.87 & $5.14 \pm 0.41$ & $0.70 \pm 0.73$ & 4.43 & 86.3 \\
14.6 & 5.94 & $5.51 \pm 0.18$ & $0.56 \pm 0.56$ & 4.94 & 89.8 \\
16.7 & 4.25 & $7.60 \pm 0.38$ & $4.17 \pm 0.45$ & 3.43 & 45.1 \\
17.7 & 5.83 & $6.65 \pm 0.27$ & $1.13 \pm 0.88$ & 5.52 & 83.0 \\
22.9 & 6.11 & $8.98 \pm 0.40$ & $2.79 \pm 1.04$ & 6.19 & 68.9 \\
30.8 & 6.37 & $12.14 \pm 0.74$ & $6.68 \pm 1.37$ & 5.46 & 45.0 \\
\hline
\end{tabular}

${ }^{5}$ Only one feedstock glucose concentration datum available as no gas was produced for this OLR

${ }^{6}$ These values may not be exact due to rounding significant figures to 2 digits. 


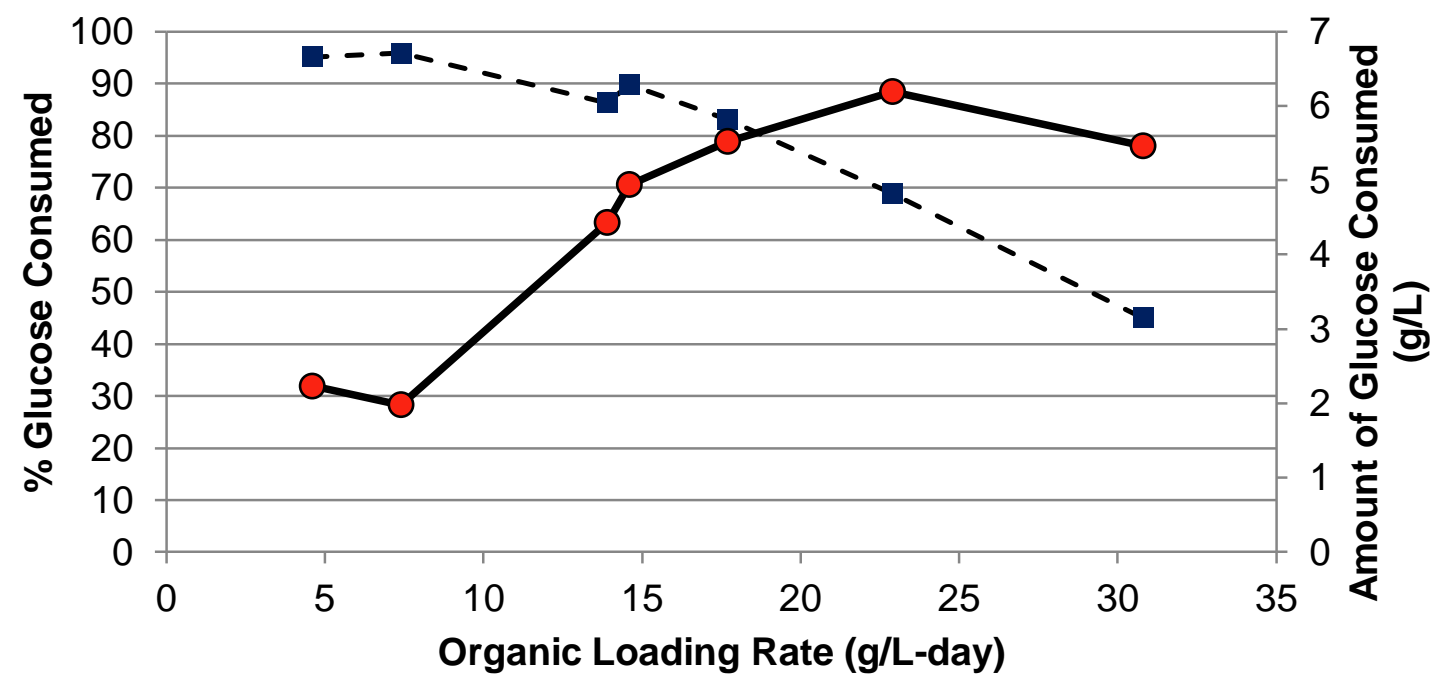

- - - \% Glucose Consumed $\quad \longrightarrow$ Amount of Glucose Consumed

Figure 4-3: Glucose consumption for all organic loading rates (OLRs) tested between $\mathrm{pH} 5.0-6.5$.

\subsubsection{Glucose-Consumed \& Glucose-Introduced Hydrogen Yields}

$\mathrm{H}_{2}$ yields on a glucose-consumed and glucose-introduced basis are discussed in this section.

On a glucose-consumed basis, at $\mathrm{pH}>5.0$, yields increased from zero to $0.56 \pm$

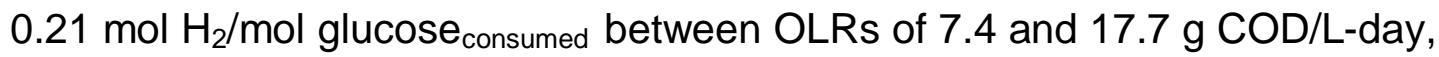
respectively. At OLRs higher than $17.7 \mathrm{~g} \mathrm{COD/L-day,} \mathrm{yields} \mathrm{stayed} \mathrm{constant}$ around $0.60 \mathrm{~mol} \mathrm{H}_{2} / \mathrm{mol}_{\text {glucose }}$ consumed (Figure 4-4 - black dashed line), indicating glucose was being converted to $\mathrm{H}_{2}$ at the maximum possible efficiency.

On a glucose-introduced basis, at $\mathrm{pH}>5.0$, yields increased almost linearly from zero at $7.4 \mathrm{~g} \mathrm{COD} / \mathrm{L}-$ day to a peak of $0.46 \pm 0.08 \mathrm{~mol} \mathrm{H}_{2} / \mathrm{mol}_{\text {glucose }}$ introduced $_{\text {at }}$ $17.7 \mathrm{~g} \mathrm{COD} / \mathrm{L}-$ day. At higher OLRs, yields decreased to $0.42 \pm 0.06 \mathrm{~mol} \mathrm{H}_{2} / \mathrm{mol}$ glucose $_{\text {introduced }}$ at $22.9 \mathrm{~g} \mathrm{COD} / \mathrm{L}$-day and $0.24 \pm 0.04 \mathrm{~mol} \mathrm{H}_{2} / \mathrm{mol}_{\text {glucose }}$ introduced 
at $30.8 \mathrm{~g} \mathrm{COD/L-day} \mathrm{(Figure} \mathrm{4-4} \mathrm{-} \mathrm{red} \mathrm{solid} \mathrm{line).} \mathrm{This} \mathrm{decrease} \mathrm{combined} \mathrm{with}$ the glucose-consumption $\mathrm{H}_{2}$ yield staying constant between 17.7 and $30.8 \mathrm{~g}$ $\mathrm{COD} / \mathrm{L}$-day indicated the first-phase was overloaded at OLRs higher than $17.7 \mathrm{~g}$ COD/L-day.

Similar to the volumetric $\mathrm{H}_{2}$ yield results, at OLRs of 7.3 and $8.1 \mathrm{~g} \mathrm{COD/L-day}$ operated at $\mathrm{pH}<5.0$, yields were higher than similar OLRs of 4.6 and $7.4 \mathrm{~g}$ COD/L-day operated at $\mathrm{pH}>5.0$, which made no gas at all (Table 4-6).

Table 4-6: $\mathrm{H}_{2}$ yields on a glucose-consumed and glucose-introduced basis for all organic loading rates (OLRs) and pHs tested at a constant 12-hr hydraulic residence time (HRT).

\begin{tabular}{cccc}
\hline \multirow{2}{*}{$\begin{array}{c}\text { OLR } \\
\text { (g COD/L-day) }\end{array}$} & pH & \multicolumn{2}{c}{$\begin{array}{c}\text { Molar } \mathrm{H}_{2} \text { Yield } \\
\text { (mol } \mathrm{H}_{2} / \mathbf{m o l}_{\text {glucose) }}\end{array}$} \\
\cline { 3 - 4 } & & $\begin{array}{c}\text { Per mol glucose } \\
\text { consumed }\end{array}$ & $\begin{array}{c}\text { Per mol glucose } \\
\text { introduced }\end{array}$ \\
\hline 4.6 & 5.77 & 0.00 & 0.00 \\
7.3 & 4.39 & $0.29 \pm 0.02$ & $0.30 \pm 0.04$ \\
7.4 & 6.14 & 0.00 & 0.00 \\
8.1 & 4.87 & $2.60 \pm 2.50$ & $0.92 \pm 0.39$ \\
12.9 & 4.24 & $0.42 \pm 0.17$ & $0.25 \pm 0.07$ \\
13.9 & 5.87 & $0.32 \pm 0.12$ & $0.34 \pm 0.14$ \\
14.6 & 5.94 & $0.32 \pm 0.11$ & $0.27 \pm 0.04$ \\
16.7 & 4.25 & $0.35 \pm 0.10$ & $0.15 \pm 0.03$ \\
17.7 & 5.83 & $0.56 \pm 0.21$ & $0.46 \pm 0.08$ \\
22.9 & 6.11 & $0.61 \pm 0.10$ & $0.42 \pm 0.06$ \\
30.8 & 6.37 & $0.62 \pm 0.25$ & $0.24 \pm 0.04$ \\
\hline
\end{tabular}




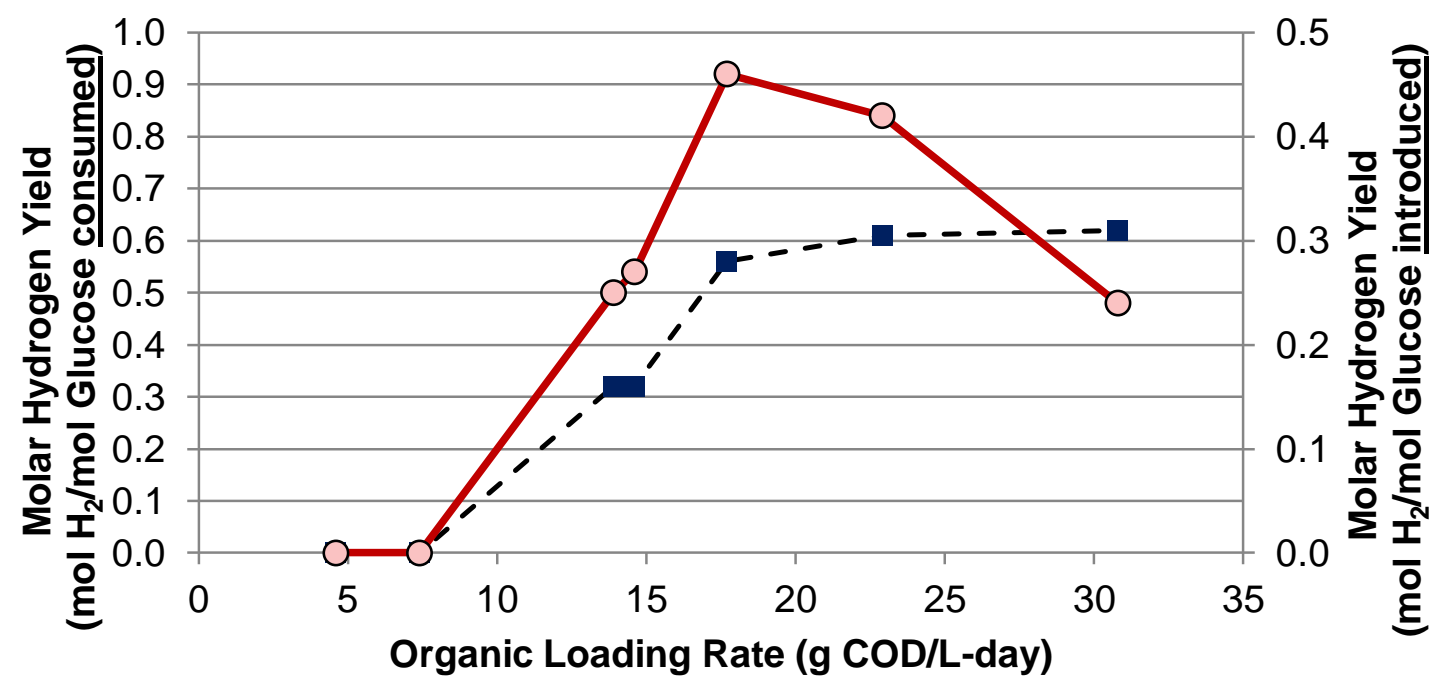

- - Glucose Consumed Basis $\quad-0$ Glucose Introduced Basis

Figure 4-4: $\mathrm{H}_{2}$ yields on a glucose-consumed and glucose-introduced basis at all organic loading rates (OLRs) tested at a constant hydraulic residence time (HRT) of 12 hrs. Only OLRs operated between pH 5.0 - 6.5 are graphed.

\subsubsection{COD Destruction}

COD destruction was calculated from influent (feedstock) COD and effluent COD data. The $\%$ COD destroyed was less than $13 \%$ at all OLRs and pHs tested (Table 4-7).

Table 4-7: Influent (feedstock) COD, effluent COD, and \% COD destruction at all organic loading rates (OLRs) tested at a constant 12-hr hydraulic residence time (HRT).

\begin{tabular}{ccccc}
\hline $\begin{array}{c}\text { OLR } \\
\text { (g COD/L-day) }\end{array}$ & $\mathbf{p H}$ & $\begin{array}{c}\text { Influent COD } \\
(\mathbf{g} / \mathbf{L})\end{array}$ & $\begin{array}{c}\text { Effluent COD } \\
(\mathbf{g} / \mathbf{L})\end{array}$ & $\begin{array}{c}\% \text { COD } \\
\text { Destroyed }\end{array}$ \\
\hline 4.6 & 5.77 & $2298 \pm 91$ & $2123 \pm 159$ & 7.6 \\
7.3 & 4.39 & $3648 \pm 160$ & $3261 \pm 80$ & 10.6 \\
7.4 & 6.14 & $3702 \pm 67$ & $3282 \pm 66$ & 11.3 \\
8.1 & 4.87 & $4066 \pm 130$ & $3916 \pm 273$ & 3.7 \\
12.9 & 4.24 & $6451 \pm 180$ & $6202 \pm 26$ & 3.9 \\
13.9 & 5.87 & $6931 \pm 410$ & $6047 \pm 219$ & 12.8 \\
14.6 & 5.94 & $7302 \pm 320$ & $6774 \pm 171$ & 7.2 \\
16.7 & 4.25 & $8345 \pm 450$ & $8391 \pm 132$ & 0.0 \\
17.7 & 5.83 & $8863 \pm 300$ & $7806 \pm 493$ & 11.9 \\
22.9 & 6.11 & $11470 \pm 92$ & $10799 \pm 151$ & 5.9 \\
30.8 & 6.37 & $15405 \pm 87.7$ & $14965 \pm 440$ & 2.9 \\
\hline
\end{tabular}




\subsubsection{COD-Introduced \& COD-Destroyed Hydrogen Yields}

Hydrogen yields on a COD-destroyed $\left(\mathrm{mol} \mathrm{H}_{2} / \mathrm{mol} \mathrm{COD}_{\text {destroyed }}\right)$ and CODintroduced ( $\mathrm{mol} \mathrm{H}_{2} / \mathrm{mol} \mathrm{COD}_{\text {introduced }}$ ) basis were calculated (Table 4-8).

On a COD-destroyed basis, for OLRs operated at $\mathrm{pH}>5.0, \mathrm{H}_{2}$ yield increased from zero at $4.6 \mathrm{~g} \mathrm{COD} / \mathrm{L}$-day to $0.71 \pm 0.40 \mathrm{~mol} \mathrm{H}_{2} / \mathrm{mol} \mathrm{COD}_{\text {destroyed }}$ at $14.6 \mathrm{~g}$ COD/L-day (Figure 4-5- black dotted line). It is possible the first peak of 0.71 mol $\mathrm{H}_{2} / \mathrm{mol} \mathrm{COD}_{\text {destroyed }} 11.0 \mathrm{~g} \mathrm{COD} / \mathrm{L}$-day is inflated because it had a high standard deviation of $\pm 0.40 \mathrm{~mol} \mathrm{H}_{2} / \mathrm{mol} \mathrm{COD}_{\text {destroyed. }}$. At the next tested OLR of $17.7 \mathrm{~g} \mathrm{COD} / \mathrm{L}$-day, the yield dipped to $0.50 \pm 0.23 \mathrm{~mol} \mathrm{H}_{2} / \mathrm{mol} \mathrm{COD}_{\text {destroyed; }}$; however, at $22.9 \mathrm{~g} \mathrm{COD} / \mathrm{L}$-day, the yield increased again to $1.06 \pm 0.16 \mathrm{~mol}$ $\mathrm{H}_{2} / \mathrm{mol} \mathrm{COD}_{\text {destroyed }}$ at $22.9 \mathrm{~g} \mathrm{COD} / \mathrm{L}$-day. At $30.8 \mathrm{~g} \mathrm{COD/L-day,} \mathrm{the} \mathrm{yield} \mathrm{dropped}$ to $0.79 \pm 0.28 \mathrm{~mol} \mathrm{H} / \mathrm{mol} \mathrm{COD}_{\text {destroyed. }}$.

On a COD-introduced basis, for OLRs operated at $\mathrm{pH}>5.0, \mathrm{H}_{2}$ yields rose linearly from zero at $7.4 \mathrm{~g} \mathrm{COD} / \mathrm{L}$-day to $0.06 \pm 0.01 \mathrm{~mol} \mathrm{H}_{2} / \mathrm{mol} \mathrm{COD}_{\text {introduced }}$ at $17.7 \mathrm{~g} \mathrm{COD} / \mathrm{L}$-day. The same yield of $0.06 \pm 0.01 \mathrm{~mol} \mathrm{H} / \mathrm{mol}^{C O D}$ introduced was observed at the next tested OLR of $22.9 \mathrm{~g} \mathrm{COD/L-day.} \mathrm{At} 30.8 \mathrm{~g} \mathrm{COD/L-day,} \mathrm{the}$ yield dropped to $0.03 \pm 0.00 \mathrm{~mol} \mathrm{H}_{2} / \mathrm{mol} \mathrm{COD}_{\text {introduced }}$ (Figure 4-5 - black solid line). 
Table 4-8: $\mathrm{H}_{2}$ yields on a COD-destroyed and COD-introduced basis for all organic loading rates (OLRs) and pHs tested at a constant 12-hr hydraulic residence time (HRT).

\begin{tabular}{cccc}
\hline & & \multicolumn{2}{c}{$\begin{array}{c}\text { Molar } \mathrm{H}_{2} \text { Yield } \\
\text { OLRol H }\end{array}$ /mol COD) } \\
\cline { 3 - 4 } (g COD/L-day) & pH & $\begin{array}{c}\text { Per mol COD } \\
\text { destroyed }\end{array}$ & $\begin{array}{c}\text { Per mol COD } \\
\text { introduced }\end{array}$ \\
\hline 4.6 & 5.77 & 0.00 & 0.00 \\
7.3 & 4.39 & $0.49 \pm 0.22$ & $0.04 \pm 0.01$ \\
7.4 & 6.14 & 0.00 & 0.00 \\
8.1 & 4.87 & $0.51 \pm 0.32$ & $0.07 \pm 0.02$ \\
12.9 & 4.24 & $0.97 \pm 0.52$ & $0.03 \pm 0.01$ \\
13.9 & 5.87 & $0.24 \pm 0.14$ & $0.05 \pm 0.02$ \\
14.6 & 5.94 & $0.71 \pm 0.40$ & $0.04 \pm 0.01$ \\
16.7 & 4.25 & $0.80 \pm 0.76$ & $0.02 \pm 0.00$ \\
17.7 & 5.83 & $0.50 \pm 0.23$ & $0.06 \pm 0.01$ \\
22.9 & 6.11 & $1.06 \pm 0.16$ & $0.06 \pm 0.01$ \\
30.8 & 6.37 & $0.79 \pm 0.28$ & $0.03 \pm 0.00$ \\
\hline
\end{tabular}

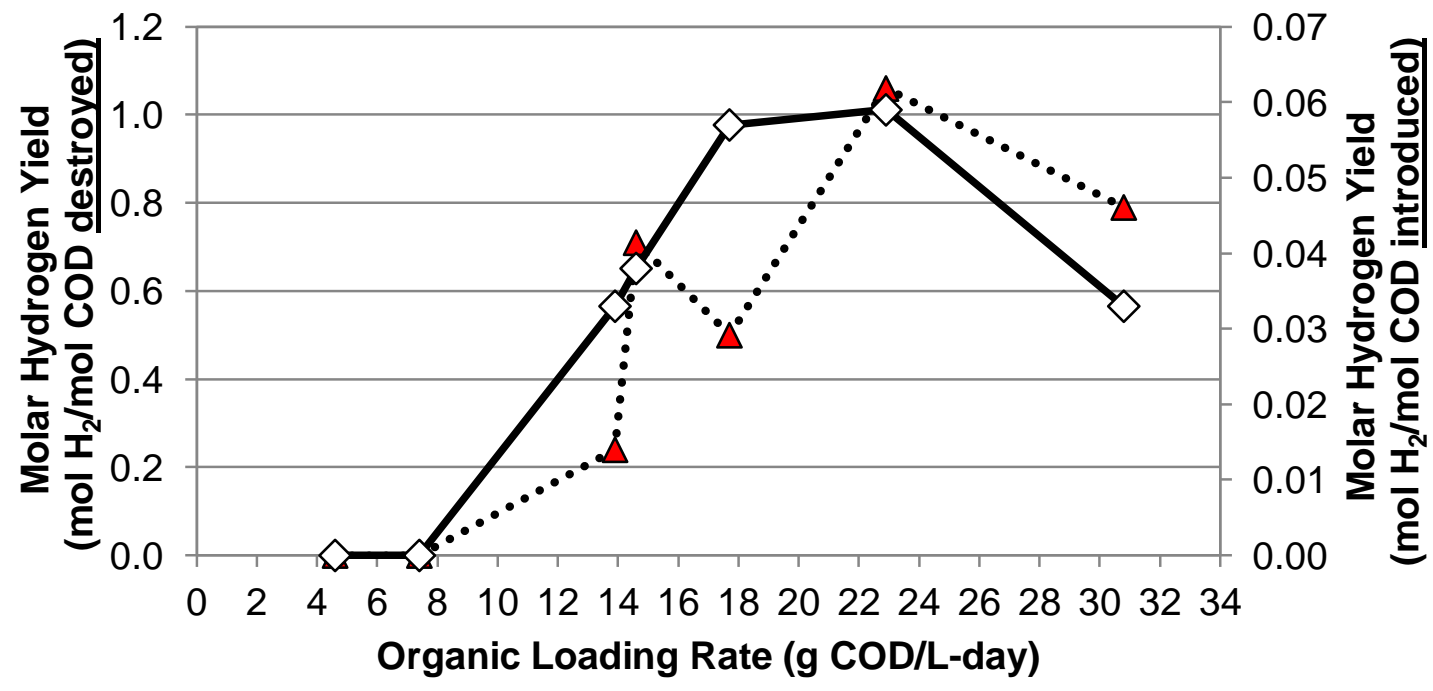

$\because \bowtie$ COD Destroyed Basis $\quad \sim$ COD Introduced Basis

Figure 4-5: $\mathrm{H}_{2}$ yields on a COD-destroyed and COD-introduced basis at all organic loading rates (OLRs) tested at a constant hydraulic residence time (HRT) of $12 \mathrm{hrs}$. Only OLRs operated between $\mathrm{pH} 5.0-6.5$ are graphed. 


\subsubsection{Chemical Oxygen Demand (COD) Balance}

A COD balance was calculated and percent recoveries were within $88-102 \%$ for all OLRs and pHs tested (Table 4-9 \& Figure 4-6).

Table 4-9: COD Balance for all organic loading rates (OLRs) tested. Percent (\%) recovery was calculated as $\left(\frac{\text { Effluent } \mathrm{COD}+\mathrm{H}_{2} \mathrm{COD} \text { Calculated }}{\operatorname{lnfluent} \mathrm{COD}}\right) \times 100 \%$.

\begin{tabular}{cccccc}
\hline $\begin{array}{c}\text { OLR } \\
\text { (g COD/L-day) }\end{array}$ & $\mathbf{p H}$ & $\begin{array}{c}\text { Influent } \\
\text { COD }^{7} \\
\text { (g/day) }\end{array}$ & $\begin{array}{c}\text { Effluent } \\
\text { COD }^{7} \\
\text { (g/day) }\end{array}$ & $\begin{array}{c}\mathbf{H}_{2} \text { COD } \\
\text { Calculated }^{8} \\
\text { (g/day) }^{8}\end{array}$ & $\begin{array}{c}\% \\
\text { Recovery }\end{array}$ \\
\hline 4.6 & 5.77 & 4.6 & 4.2 & 0.00 & 92.4 \\
7.3 & 4.39 & 7.3 & 6.5 & 0.16 & 91.6 \\
7.4 & 6.14 & 7.4 & 6.6 & 0.01 & 88.9 \\
8.1 & 4.87 & 8.1 & 7.8 & 0.29 & 99.9 \\
12.9 & 4.24 & 12.9 & 12.4 & 0.21 & 97.8 \\
13.9 & 5.87 & 13.9 & 12.1 & 0.30 & 89.4 \\
14.6 & 5.94 & 14.6 & 13.5 & 0.28 & 94.7 \\
16.7 & 4.25 & 16.7 & 16.8 & 0.20 & 101.7 \\
17.7 & 5.83 & 17.7 & 15.6 & 0.51 & 90.9 \\
22.9 & 6.11 & 22.9 & 21.6 & 0.68 & 97.1 \\
30.8 & 6.37 & 30.8 & 29.9 & 0.51 & 98.8 \\
\hline
\end{tabular}

${ }^{7}$ Influent or Effluent COD $(\mathrm{g} /$ day $)=\left(\operatorname{COD}\right.$ Measured $\left.\left(\frac{\mathrm{mg}}{\mathrm{L}}\right)\right)\left(\frac{1 \mathrm{~g} \operatorname{COD}}{1000 \mathrm{mg} \mathrm{COD}}\right)\left(\frac{1 \mathrm{~L}}{\mathrm{HRT}(\mathrm{hr})}\right)\left(\frac{24 \mathrm{hr}}{\text { day }}\right)$

${ }^{8} \mathrm{H}_{2} \operatorname{COD}(\mathrm{g} /$ day $)=\left(\right.$ Vol. $\mathrm{H}_{2}$ Yield $\left.\left(\frac{\mathrm{LH} \mathrm{H}_{2}}{\mathrm{~L} \text {-day }}\right)\right)(1$-L liquid volume $)\left(\frac{1}{0.08206 \mathrm{~L} \text {-atm/mol-K}}\right)\left(\frac{1 \mathrm{~atm}}{293 \mathrm{~K})}\right)\left(\frac{16 \mathrm{~g} \mathrm{COD}}{\mathrm{mol} \mathrm{H}_{2}}\right)$ 


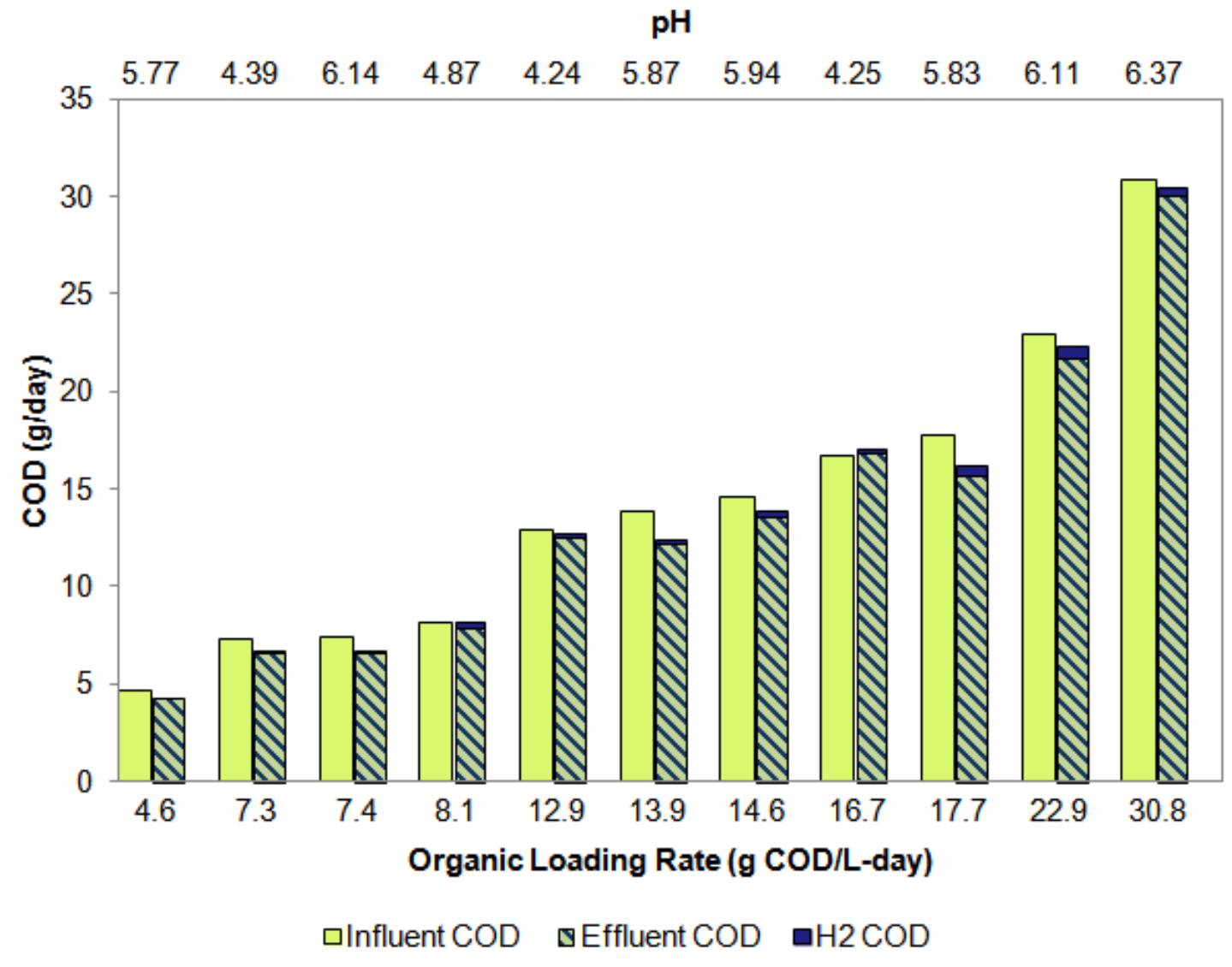

Figure 4-6: COD balance at all organic loading rates (OLRs) and pHs tested.

\subsubsection{Discussion}

Results from the OLR experiment are discussed in the paragraphs below.

Organic loading rate and $\mathrm{pH}$ had a noticeable effect on hydrogen yields and substrate utilization efficiency. Glucose consumption was greater than $45 \%$ at all OLRs tested, but an interesting observation is at OLRs that produced no biogas (4.6 and $7.4 \mathrm{~g} \mathrm{COD/L-day),} \mathrm{all} \mathrm{of} \mathrm{the} \mathrm{glucose} \mathrm{was} \mathrm{essentially} \mathrm{consumed} \mathrm{(95.1 \%}$ and $95.8 \%$ consumption, respectively). These OLRs were operated at $\mathrm{pH}>5.0$, which is typically considered beneficial for $\mathrm{H}_{2}$ production, so some biogas 
production was expected. Another odd finding is at OLRs of 7.3 and $8.1 \mathrm{~g}$ COD/L-day, which were operated at $\mathrm{pH}<5.0$ (not typically considered an ideal $\mathrm{pH}$ for $\mathrm{H}_{2}$ production), significantly more biogas was produced than for OLRs of 4.6 and $7.4 \mathrm{~g} \mathrm{COD/L-day} \mathrm{,operated} \mathrm{at} \mathrm{pH}>5.0$.

The metabolic activity of acetogens at different $\mathrm{pHs}$ may explain these observations. Acteogens, which consume $\mathrm{H}_{2}, \mathrm{CO}_{2}$, and/or glucose, are a type of bacteria ubiquitous in anoxic environments (Dürre, 2005), and may have been introduced into the digesters through the untreated sludge inoculum. At $\mathrm{pH}<5.0$, most acetogens are not able to grow (Dürre, 2005). Therefore, the lack of acetogenic activity at $\mathrm{pH}<5.0$ may have allowed $\mathrm{H}_{2}$ to be produced without any bacteria consuming the gas. Conversely, at $\mathrm{pH}>5.0$, acetogens may have been actively converting $\mathrm{H}_{2}, \mathrm{CO}_{2}$ and glucose into acetate. This may explain why although glucose consumption was significant at 4.6 and $7.4 \mathrm{~g} \mathrm{COD/L-day}$ (operated at $\mathrm{pH}>5.0$ ), no biogas was produced and the COD destruction was small.

At tested OLRs at or above $13.9 \mathrm{~g} \mathrm{COD/L-day,} \mathrm{operated} \mathrm{at} \mathrm{pH}>5.0$, hydrogen was produced even though acetogens were active in this $\mathrm{pH}$ range. A possible explanation why significant hydrogen production occurred above $13.9 \mathrm{~g} \mathrm{COD/L-}$ day is the $\mathrm{H}_{2}$-producing bacteria may have outperformed the acetogens at a breakpoint OLR between 7.4 and $13.9 \mathrm{~g}$ COD/L-day.

S.H. Kim et al. performed a similar experiment where sucrose concentration was changed from $10-60 \mathrm{~g} \mathrm{COD} / \mathrm{L}$ at a constant 12-hr HRT, and found acetogens 
were present at $10 \mathrm{~g} \mathrm{COD/L}$ with decreased $\mathrm{H}_{2}$ production, whereas at $30 \mathrm{~g}$ $\mathrm{COD} / \mathrm{L}$, no acetogens were present and hydrogen production was maximized (2006). Kim et al.'s experiment and this project's results showed a breakpoint substrate concentration likely exists where acetogens are more dominant at concentrations lower than this breakpoint. For this thesis project, that breakpoint is likely at or below $13.9 \mathrm{~g} \mathrm{COD/L-day} \mathrm{(or} 7.0 \mathrm{~g} \mathrm{COD/L} \mathrm{glucose} \mathrm{at} \mathrm{a} \mathrm{12-hr} \mathrm{HRT),}$ because at OLRs lower than $13.9 \mathrm{~g} \mathrm{COD/L-day} \mathrm{and} \mathrm{pH}>5.0$, no biogas was produced.

COD destruction between the influent and effluent was relatively small (less than $13 \%$ ) compared to the estimated COD destruction of $65 \%$ for a methaneproducing anaerobic digester operated at a 30-day HRT (Metcalf \& Eddy, 2013) . However, this was expected because the glucose entering the first-phase digesters was converted to hydrogen gas, carbon dioxide, acetic acid, and other VFAs as end products (assuming acetogens were not dominant). Although some $\operatorname{COD}\left(16 \mathrm{~g} \mathrm{COD} / \mathrm{mol} \mathrm{H}_{2}\right)$ exited the digesters in the form of $\mathrm{H}_{2}\left(\mathrm{CO}_{2}\right.$ has no COD), most of the COD contributed by glucose was converted to COD as VFAs, and therefore the COD destruction was relatively little. This explains why COD destruction was small compared to glucose consumption (greater than $45 \%$ at all OLRs tested).

Although COD destruction was small, attached growth, an important COD source, was not accounted for. If attached growth COD was considered, the COD destruction would likely be even smaller. Also, because Effluent $\mathrm{COD}+\mathrm{H}_{2}$ 
COD tended to be less than Influent COD, the attached growth COD could make up for this remaining difference in the COD balance.

To prove attached growth had more COD, at the end of one of the experiments a regular COD sample was collected from each duplicate first-phase digester. Next, the digesters were shaken vigorously to dislodge attached growth into the liquid. Another COD sample was collected from each digester after shaking occurred. In comparison to the non-shaken COD samples, the shaken COD samples had an average of $14 \%$ more COD.

The glucose-consumption $\mathrm{H}_{2}$ yields in this project were not as high as the typical values (1-2 $\mathrm{mol} \mathrm{H}_{2} / \mathrm{mol}_{\text {glucose }}$ consumed $)$ obtained in literature. This is likely due to the high error in glucose results, and the possibility samples degraded as they were not tested until 3-12 months after an experiment ended.

The excellent recoveries (88-102\% recovery) from the COD balance showed most of the COD entering the digesters was conserved in the form of effluent COD and $\mathrm{H}_{2} \mathrm{COD}$; however, the balance is slightly diminished because the influent and effluent CODs were very similar and usually within the $\pm 7.5 \%$ error of the COD test. As mentioned earlier, attached growth COD was not included in the COD balance, but if it was not ignored the recoveries would be even closer to 100\%. Therefore, the COD balance still likely validates data integrity.

\subsubsection{Ideal Operating OLR}

The goal of the OLR experiment was to determine which OLR maximized $\mathrm{H}_{2}$ yields. At an OLR of $22.9 \mathrm{~g} \mathrm{COD/L-day,} \mathrm{all} \mathrm{H}_{2}$ yields, except on a glucose- 
introduced basis, were maximized (Table 4-10). Therefore, $22.9 \mathrm{~g}$ COD/L-day was the target OLR used for all future experiments.

Table 4-10: $\mathrm{H}_{2}$ yield summary for the ideal OLR of $22.9 \mathrm{~g}$ COD/L-day.

\begin{tabular}{|c|c|c|c|c|}
\hline \multirow{2}{*}{$\begin{array}{c}\text { Volumetric } \\
\mathrm{H}_{2} \text { Yield } \\
\text { (L } \mathrm{H}_{2} / \\
\text { L-day) } \\
\end{array}$} & \multicolumn{2}{|c|}{$\begin{array}{c}\text { Molar } \mathrm{H}_{2} \text { Yield (Glucose) } \\
\text { (mol } \mathrm{H}_{2} / \text { mol glucose) }\end{array}$} & \multicolumn{2}{|c|}{$\begin{array}{l}\text { Molar } \mathrm{H}_{2} \text { Yield (COD) } \\
\left(\mathrm{mol} \mathrm{H}_{2} / \text { mol COD) }\right.\end{array}$} \\
\hline & $\begin{array}{c}\text { Per mol glucose } \\
\text { consumed }\end{array}$ & $\begin{array}{c}\text { Per mol glucose } \\
\text { introduced }\end{array}$ & $\begin{array}{c}\text { Per mol COD } \\
\text { destroyed }\end{array}$ & $\begin{array}{l}\text { Per mol COD } \\
\text { introduced }\end{array}$ \\
\hline $1.02 \pm 0.13$ & $0.61 \pm 0.10$ & $0.42 \pm 0.06$ & $1.06 \pm 0.16$ & $0.06 \pm 0.01$ \\
\hline Maximized & At Max Threshold & 2nd Highest & Maximized & Maximized \\
\hline
\end{tabular}

\subsection{Hydraulic Residence Time (HRT) Experiment}

This experiment was conducted to determine which HRT maximized hydrogen

yields at a constant target OLR of $22.9 \mathrm{~g} \mathrm{COD/L-day} \mathrm{(determined} \mathrm{from} \mathrm{the}$ previous experiment). The procedures and results of this experiment are discussed in this section.

\subsubsection{Experimental Procedures}

HRTs ranging from 6 - 24 hrs were tested (Table 4-11) while keeping OLR constant at a target of $22.9 \mathrm{~g} \mathrm{COD/L-day.} \mathrm{The} \mathrm{18-hr} \mathrm{HRT} \mathrm{was} \mathrm{repeated}$ unintentionally at different $\mathrm{pHs}(6.33$ and 6.73$)$ to see if the same results could be reproduced. Feedstock glucose concentration was increased or decreased proportionally with HRT to keep the OLR constant. The average OLR for all HRTs tested (besides the 12-hr HRT) was $20.9 \pm 1.4 \mathrm{~g} \mathrm{COD/L-day.}$ 
Table 4-11: Summary of hydraulic residence times (HRTs) and steady-state pHs tested for the HRT experiment. All HRTs were operated at a constant organic loading rate (OLR) of $22.9 \mathrm{~g} \mathrm{COD/L-day.}$

\begin{tabular}{ccc}
\hline $\begin{array}{c}\text { OLR } \\
\text { (g COD/L-day) }\end{array}$ & $\begin{array}{c}\text { HRT } \\
\text { (hr) }\end{array}$ & pH \\
\hline 21.5 & 6 & 5.93 \\
22.9 & 12 & 6.11 \\
22.5 & 15 & 6.27 \\
21.3 & 18 & 6.33 \\
20.1 & 18 & 6.73 \\
19.0 & 24 & 6.28 \\
\hline
\end{tabular}

\subsubsection{Volumetric Hydrogen Yields \& Hydrogen Composition}

Volumetric $\mathrm{H}_{2}$ yield was highest (1.02 $\pm 0.13 \mathrm{~L} \mathrm{H}_{2} / \mathrm{L}$-day) at a 12-hr HRT (same as previous experiment). At HRTs of 15 and 18 (pH 6.33) hrs, similar $\mathrm{H}_{2}$ yields of $0.86 \pm 0.11 \mathrm{~L} \mathrm{H}_{2} / \mathrm{L}$-day and $0.90 \pm 0.20$ were calculated. At HRTs higher than 18 hours, volumetric $\mathrm{H}_{2}$ yields decreased to roughly $0.60 \mathrm{~L} \mathrm{H}_{2} / \mathrm{L}$-day. The 18-hr HRT was repeated at a higher $\mathrm{pH}$ of 6.73 , and the yield was $0.92 \pm 0.16 \mathrm{~L} \mathrm{H}_{2} / \mathrm{L}$-day, which was not statistically different from $0.90 \pm 0.20 \mathrm{~L} \mathrm{H}_{2} / \mathrm{L}$-day obtained for the original 18-hr HRT operated at a lower pH of 6.33 (Table 4-12 \& Figure 4-7).

Because the 18-hr HRT operated at pH 6.33 had an OLR closer to $22.9 \mathrm{~g}$ $\mathrm{COD} / \mathrm{L}$-day and was within the optimal $\mathrm{pH}$ range of $5.0-6.5$ for $\mathrm{H}_{2}$ production, this data set is graphed instead of the 18-hr HRT operated at pH 6.73.

Hydrogen compositions ranged between 62.9 and $80.3 \% \mathrm{H}_{2}$ for all HRTs tested (Table 4-12). 
Table 4-12: Volumetric $\mathrm{H}_{2}$ yields, and $\mathrm{H}_{2}$ composition measured for all hydraulic residence times (HRTs) and pHs tested in the HRT experiment (all operated at a target organic loading rate (OLR) of $22.9 \mathrm{~g} \mathrm{COD/L-day).}$

\begin{tabular}{ccccc}
\hline $\begin{array}{c}\text { OLR } \\
\text { (g COD/L-day) }\end{array}$ & $\begin{array}{c}\text { HRT } \\
\text { (hr) }\end{array}$ & pH & $\begin{array}{c}\text { Percent } \\
\mathbf{H}_{2}(\%)\end{array}$ & $\begin{array}{c}\text { Vol. } \mathbf{H}_{2} \text { Yield } \\
\left(\mathbf{L} \mathbf{H}_{2} / \text { L-day }\right)\end{array}$ \\
\hline 21.5 & 6 & 5.93 & 70.4 & $0.72 \pm 0.16$ \\
22.9 & 12 & 6.11 & 64.7 & $1.02 \pm 0.13$ \\
22.5 & 15 & 6.27 & 62.9 & $0.86 \pm 0.11$ \\
21.3 & 18 & 6.33 & 67.3 & $0.90 \pm 0.20$ \\
20.1 & 18 & 6.73 & 80.3 & $0.92 \pm 0.16$ \\
19.0 & 24 & 6.28 & 64.7 & $0.56 \pm 0.11$ \\
\hline
\end{tabular}

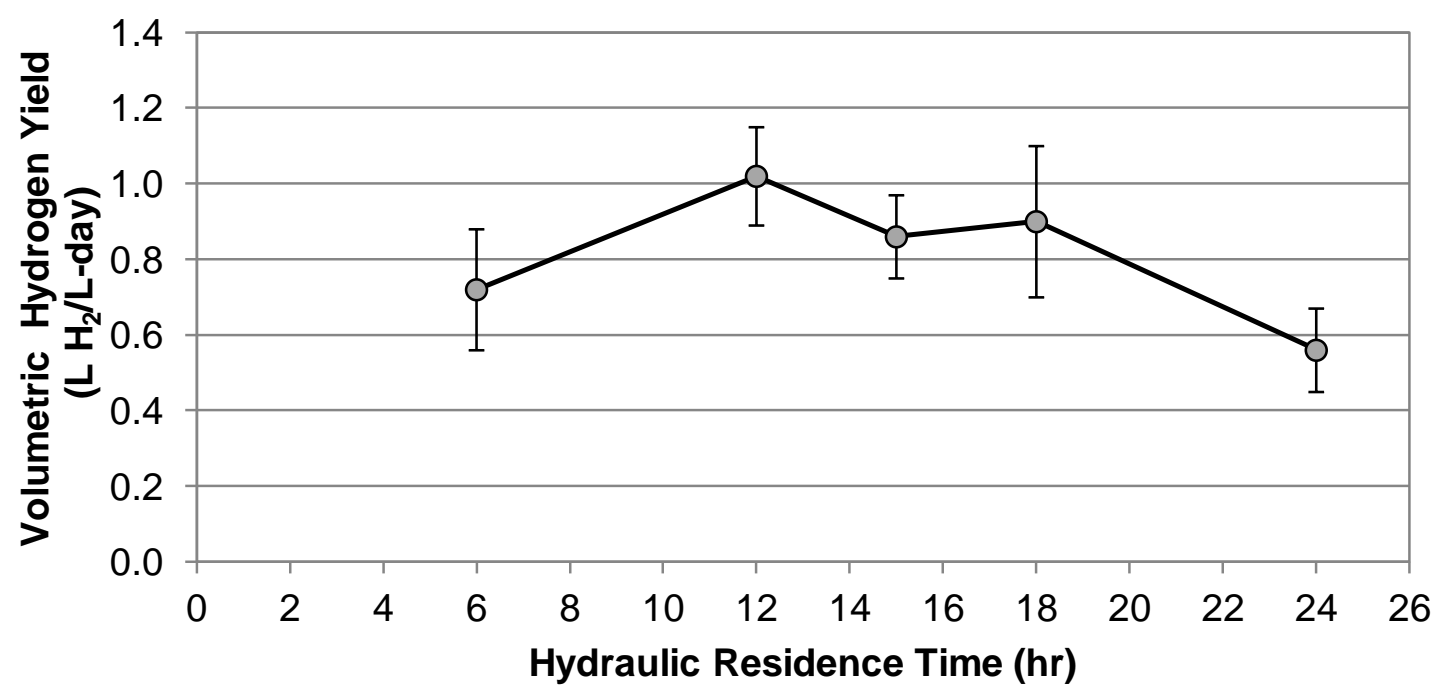

Figure 4-7: Volumetric $\mathrm{H}_{2}$ yields measured for all hydraulic residence times (HRTs) tested at a target organic loading rate (OLR) of $22.9 \mathrm{~g} \mathrm{COD/L-day} \mathrm{and}$ between $\mathrm{pH} 5.0-6.5$.

\subsubsection{Glucose Consumption}

Glucose consumption was calculated from influent (feedstock) glucose and effluent glucose concentrations (Table 4-13). Glucose consumption was highest at the 6-hr HRT (74.7\%) and dropped linearly to $63.8 \%$ at the 15-hr HRT. After the 15-hr HRT, glucose consumption decreased to $33.7 \%$ and $24.0 \%$ at the 18 hr-HRT (pH 6.33) and 24-hr HRT (Figure 4-8 - dashed line). 
The amount of glucose consumed increased linearly from $4.10 \mathrm{~g} / \mathrm{L}$ at the $6-\mathrm{hr}$ HRT to $7.68 \mathrm{~g} / \mathrm{L}$ at the 15-hr HRT. At the 18-hr HRT (pH 6.33) and 24-hr HRT, the amount of glucose consumed decreased to 3.59 and $3.15 \mathrm{~g} / \mathrm{L}$, respectively (Figure 4-8 - solid line)

Table 4-13: Influent (feedstock) glucose, effluent glucose, glucose consumed, and \% glucose consumption at all hydraulic residence times (HRTs) and pHs tested at a target organic loading rate (OLR) of $22.9 \mathrm{~g} \mathrm{COD} / \mathrm{L}$-day.

\begin{tabular}{cccccc}
\hline $\begin{array}{c}\text { HRT } \\
\mathbf{( h r})\end{array}$ & $\mathbf{p H}$ & $\begin{array}{c}\text { Influent } \\
\text { Glucose } \\
\mathbf{( g / L )}\end{array}$ & $\begin{array}{c}\text { Effluent } \\
\text { Glucose } \\
\mathbf{( g / L )}\end{array}$ & $\begin{array}{c}\text { Glucose } \\
\text { Consumed } \\
(\mathbf{g} / \mathbf{L})^{\mathbf{1 0}}\end{array}$ & $\begin{array}{c}\text { \% Glucose } \\
\text { Consumed }\end{array}$ \\
\hline 6 & 5.93 & $5.48^{9}$ & $1.39 \pm 0.12$ & 4.10 & 74.7 \\
12 & 6.11 & $8.98 \pm 0.40$ & $2.79 \pm 1.04$ & 6.19 & 68.9 \\
15 & 6.27 & $12.05 \pm 1.92$ & $4.36 \pm 0.54$ & 7.68 & 63.8 \\
18 & 6.33 & $10.65 \pm 1.90$ & $7.06 \pm 2.44$ & 3.59 & 33.7 \\
18 & 6.73 & $14.85^{9}$ & $9.89 \pm 0.74$ & 4.96 & 33.4 \\
24 & 6.28 & $13.13 \pm 4.49$ & $9.98 \pm 1.72$ & 3.15 & 24.0 \\
\hline
\end{tabular}

${ }^{9}$ Only one feedstock glucose concentration datum available

${ }^{10}$ These values may not be exact due to rounding significant figures to 2 digits.

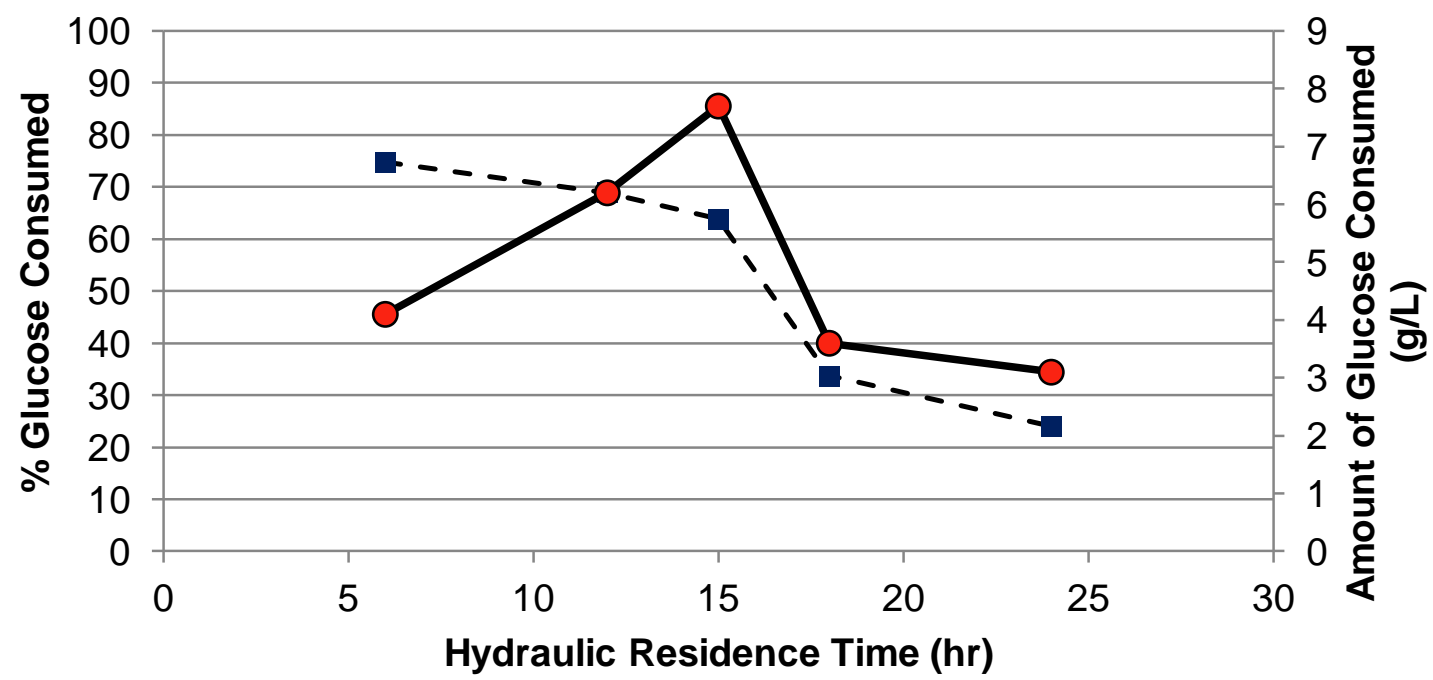

- - \% Glucose Consumed $\quad \longrightarrow$ Amount of Glucose Consumed

Figure 4-8: Glucose consumption at all hydraulic residence times (HRTs) tested between $\mathrm{pH} 5.0$ and 6.5. 


\subsubsection{Glucose-Consumed \& Glucose-Introduced Hydrogen Yields}

$\mathrm{H}_{2}$ yields on a glucose-consumed and glucose-introduced basis (Table 4-14) are discussed in this section.

On a glucose-consumed basis, the lowest glucose-consumed yield of $0.29 \pm 0.05$ mol $\mathrm{H}_{2} / \mathrm{mol}_{\text {glucose }}$ consumed occurred at the 6-hr HRT. At higher HRTs (12, 15, 24

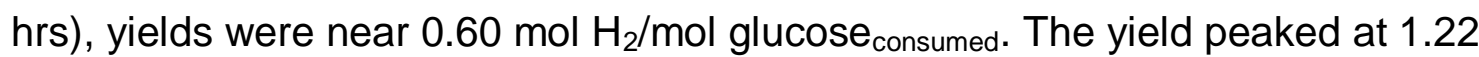
$\pm 0.69 \mathrm{~mol} \mathrm{H}_{2} / \mathrm{mol}$ glucose consumed $_{\text {for }}$ the 18-hr HRT operated at $\mathrm{pH} 6.33$ (Figure 4-9 - black dashed line), but this value may have been inflated by unusually small glucose destruction in one of the digesters for one day during steady-state. Compared to the 18-hr HRT operated at $\mathrm{pH} 6.73$, which had a yield of $0.84 \mathrm{~mol}$

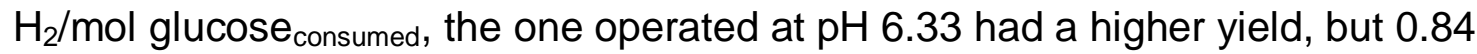
mol $\mathrm{H}_{2} / \mathrm{mol}$ glucose $e_{\text {consumed }}$ falls within $1.22 \pm 0.69 \mathrm{~mol} \mathrm{H}_{2} / \mathrm{mol}$ glucose consumed, $_{\text {, }}$ so the yields at both pHs may not be statistically different.

On a glucose-introduced basis, the lowest yield of $0.21 \pm 0.03 \mathrm{~mol} \mathrm{H} / \mathrm{mol}$ glucose $_{\text {introduced }}$ occurred at a 6 -hr HRT. At a 12-hr HRT, yield rose to $0.42 \pm 0.06$ $\mathrm{mol} \mathrm{H}_{2} / \mathrm{mol} \mathrm{glucose}_{\text {introduced}}$, and then dropped to $0.34 \pm 0.06 \mathrm{~mol} \mathrm{H}_{2} / \mathrm{mol}$ glucose $_{\text {introduced }}$ at a 15-hr HRT. At a 18-hr HRT (pH 6.33), yield increased to 0.47 $\pm 0.14 \mathrm{~mol} \mathrm{H}_{2} / \mathrm{mol}$ glucose $\mathrm{introduced}_{\text {and }}$ andopped again to $0.28 \pm 0.18 \mathrm{~mol} \mathrm{H}_{2} / \mathrm{mol}$ glucose $_{\text {introduced }}$ at a 24-hr HRT (Figure 4-9 - red solid line). The 18-hr HRT operated at $\mathrm{pH} 6.73$ had a lower yield $\left(0.32 \pm 0.10 \mathrm{~mol} \mathrm{H}_{2} / \mathrm{mol}_{\text {glucose }}\right.$ introduced $)$ than the one operated at $\mathrm{pH} 6.33\left(0.47 \pm 0.14 \mathrm{~mol} \mathrm{H}_{2} / \mathrm{mol}_{\text {glucose }}\right.$ introduced $)$. 
Table 4-14: $\mathrm{H}_{2}$ yields on a glucose-consumed and glucose-introduced basis for all hydraulic residence times (HRTs) and pHs tested.

\begin{tabular}{cccc}
\hline \multirow{2}{*}{$\begin{array}{c}\text { HRT } \\
\text { (hr) }\end{array}$} & pH & \multicolumn{2}{c}{$\begin{array}{c}\text { Molar } \mathrm{H}_{2} \text { Yield } \\
\text { (mol } \mathrm{H}_{2} / \mathbf{m o l}_{\text {glucose) }}\end{array}$} \\
\cline { 3 - 4 } & & $\begin{array}{c}\text { Per mol glucose } \\
\text { consumed }\end{array}$ & $\begin{array}{c}\text { Per mol glucose } \\
\text { introduced }\end{array}$ \\
\hline 6 & 5.93 & $0.29 \pm 0.05$ & $0.21 \pm 0.03$ \\
12 & 6.11 & $0.61 \pm 0.10$ & $0.42 \pm 0.06$ \\
15 & 6.27 & $0.54 \pm 0.14$ & $0.34 \pm 0.06$ \\
18 & 6.33 & $1.22 \pm 0.69$ & $0.47 \pm 0.14$ \\
18 & 6.73 & $0.84^{11}$ & $0.32 \pm 0.10$ \\
24 & 6.28 & $0.65 \pm 0.22$ & $0.28 \pm 0.18$ \\
\hline
\end{tabular}

${ }^{11}$ Glucose measurements could only be attained for one digester.

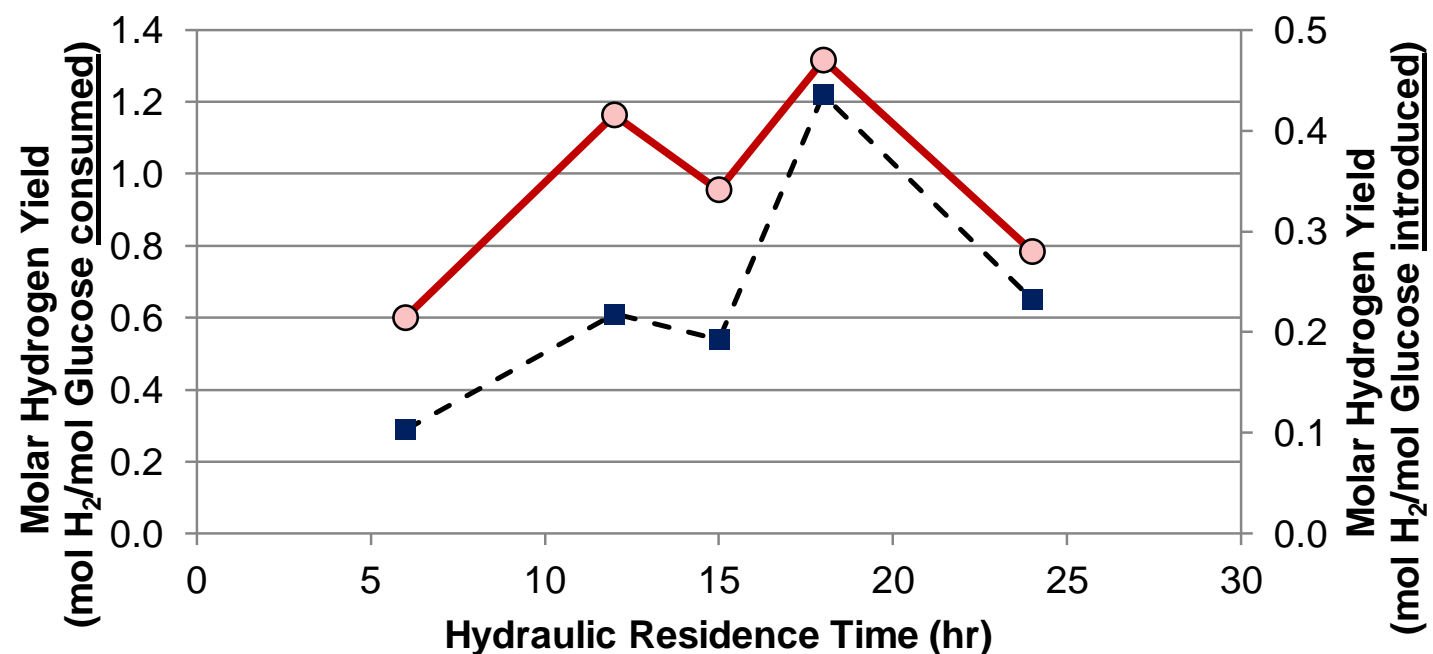

- - - Glucose Consumed Basis $\quad-0$-Glucose Introduced Basis

Figure 4-9: $\mathrm{H}_{2}$ yields on a glucose-consumed and glucose-introduced basis at all hydraulic residence times (HRTs) tested. Only HRTs operated between $\mathrm{pH} 5.0-6.5$ are graphed.

\subsubsection{COD Destruction}

COD destruction was calculated from influent (feedstock) COD and effluent COD data. The \% COD destroyed was less than $11 \%$ at all HRTs and pHs tested (Table 4-15). 
Table 4-15: Influent (feedstock) COD, effluent COD, and \% COD destruction at all hydraulic residence times (HRTs) tested.

\begin{tabular}{ccccc}
\hline $\begin{array}{c}\text { HRT } \\
\text { (hr) }\end{array}$ & $\mathbf{p H}$ & $\begin{array}{c}\text { Influent COD } \\
(\mathbf{g} / \mathbf{L})\end{array}$ & $\begin{array}{c}\text { Effluent COD } \\
(\mathbf{g} / \mathbf{L})\end{array}$ & $\begin{array}{c}\text { \% COD } \\
\text { Destroyed }\end{array}$ \\
\hline 6 & 5.93 & $5373 \pm 154$ & $5214 \pm 437$ & 3.0 \\
12 & 6.11 & $11470 \pm 92$ & $10799 \pm 151$ & 5.9 \\
15 & 6.27 & $14073 \pm 453$ & $13063 \pm 305$ & 7.2 \\
18 & 6.33 & $15961 \pm 2208$ & $14295 \pm 493$ & 10.4 \\
18 & 6.73 & $15104 \pm 142$ & $14449 \pm 224$ & 4.3 \\
24 & 6.28 & $18978 \pm 1628$ & $18513 \pm 919$ & 2.4 \\
\hline
\end{tabular}

4.4.6 COD-Introduced \& COD-Destroyed Hydrogen Yields

$\mathrm{H}_{2}$ yields on a COD-destroyed and COD-introduced basis (Table 4-16) are discussed in this section.

On a COD-destroyed basis, $\mathrm{H}_{2}$ yields rose from $0.43 \pm 0.13 \mathrm{~mol} \mathrm{H}_{2} / \mathrm{mol}$ $\mathrm{COD}_{\text {destroyed }}$ at a $6-\mathrm{hr} \mathrm{HRT}$ to a peak of $1.06 \pm 0.16 \mathrm{~mol} \mathrm{H}_{2} / \mathrm{mol} \mathrm{COD}_{\text {destroyed }}$ at a 12-hr HRT. After the 12-hr HRT, $\mathrm{H}_{2}$ yields dropped linearly to $0.32 \pm 0.19 \mathrm{~mol}$ $\mathrm{H}_{2} / \mathrm{mol} \mathrm{COD}_{\text {destroyed }}$ at an 18-hr HRT (pH 6.33). At a 24-hr HRT, $\mathrm{H}_{2}$ yield rose to $0.56 \pm 0.25 \mathrm{~mol} \mathrm{H}_{2} / \mathrm{mol} \mathrm{COD}_{\text {destroyed }}$ (Figure 4-10 - black dotted line).

Compared to the 18-hr HRT (pH 6.33), the 18-hr HRT (pH 6.73) had a significantly higher $\mathrm{H}_{2}$ yield of $1.46 \pm 0.91 \mathrm{~mol} \mathrm{H}_{2} / \mathrm{mol} \mathrm{COD}_{\text {destroyed }}$, but this value may be inflated due to unusually small COD destruction on the last-day of steady-state.

On a COD-introduced basis, $\mathrm{H}_{2}$ yields were between 0.04 and $0.06 \mathrm{~mol} \mathrm{H}_{2} / \mathrm{mol}$ $C O D_{\text {introduced }}$ at all HRTs tested (Figure 4-10 - black solid line). The highest $\mathrm{H}_{2}$ yields of $0.06 \mathrm{~mol} \mathrm{H}_{2} / \mathrm{mol} \mathrm{COD}_{\text {introduced }}$ Occurred at the 12-hr and 18-hr $(\mathrm{pH} \mathrm{6.33)}$ 
HRTs. The 18-hr HRT ( $\mathrm{pH} 6.73$ ) had an identical $\mathrm{H}_{2}$ yield of $0.06 \mathrm{~mol} \mathrm{H}_{2} / \mathrm{mol}$ $\mathrm{COD}_{\text {introduced }}$ compared to the 18-hr HRT (pH 6.33).

Table 4-16: $\mathrm{H}_{2}$ yields on a COD-destroyed and COD-introduced basis for all hydraulic residence times (HRTs) and pHs tested.

\begin{tabular}{cccc}
\hline HRT & & \multicolumn{2}{c}{$\begin{array}{c}\text { Molar } \mathrm{H}_{2} \text { Yield } \\
\left(\mathbf{m o l ~ H} / \text { mol COD }_{2}\right.\end{array}$} \\
\cline { 3 - 4 }$(\mathbf{h r})$ & pH & $\begin{array}{c}\text { Per mol COD } \\
\text { destroyed }\end{array}$ & $\begin{array}{c}\text { Per mol COD } \\
\text { introduced }\end{array}$ \\
\hline 6 & 5.93 & $0.43 \pm 0.13$ & $0.04 \pm 0.00$ \\
12 & 6.11 & $1.06 \pm 0.16$ & $0.06 \pm 0.01$ \\
15 & 6.27 & $0.68 \pm 0.25$ & $0.05 \pm 0.00$ \\
18 & 6.33 & $0.32 \pm 0.19$ & $0.06 \pm 0.02$ \\
18 & 6.73 & $1.46 \pm 0.91$ & $0.06 \pm 0.01$ \\
24 & 6.28 & $0.56 \pm 0.25$ & $0.04 \pm 0.01$ \\
\hline
\end{tabular}

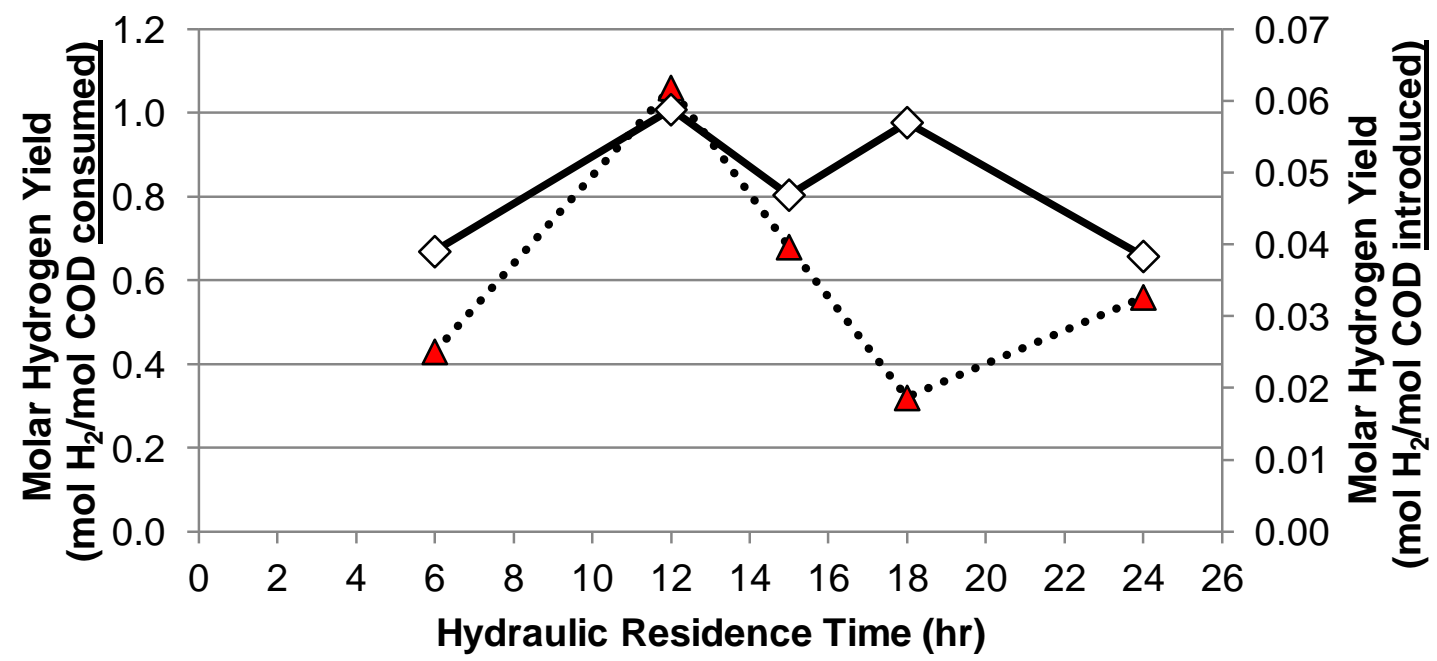

$\because \bowtie \cdot$ COD Destroyed Basis $\quad \approx$ COD Introduced Basis

Figure 4-10: $\mathrm{H}_{2}$ yields on a COD-destroyed and COD-introduced basis at all hydraulic residence times (HRTs) tested. Only HRTs operated between pH 5.0 - 6.5 are graphed.

\subsubsection{Chemical Oxygen Demand (COD) Balance}

A COD balance was calculated and percent recoveries were within $92-100 \%$

(Table 4-17 and Figure 4-11) at all HRTs tested. 
Table 4-17: COD Balance for all HRTs tested. Percent (\%) recovery was calculated as $\left(\frac{\text { Effluent } \mathrm{COD}+\mathrm{H}_{2} \mathrm{COD} \text { Calculated }}{\text { Influent } \mathrm{COD}}\right) \times 100 \%$.

\begin{tabular}{cccccc}
\hline $\begin{array}{c}\text { HRT } \\
\text { (hr) }\end{array}$ & pH & $\begin{array}{c}\text { Influent } \\
\text { COD }^{12} \\
\text { (g/day) }^{\text {g }}\end{array}$ & $\begin{array}{c}\text { Effluent } \\
\text { COD }^{12} \\
(\mathbf{g} / \text { day) }\end{array}$ & $\begin{array}{c}\mathbf{H}_{2} \text { COD } \\
\text { Calculated }^{13} \\
\text { (g/day) }\end{array}$ & $\begin{array}{c}\% \\
\text { Recovery }\end{array}$ \\
\hline 6 & 5.93 & 21.5 & 20.9 & 0.48 & 99.3 \\
12 & 6.11 & 22.9 & 21.6 & 0.68 & 97.1 \\
15 & 6.27 & 22.5 & 20.9 & 0.57 & 95.4 \\
18 & 6.33 & 21.3 & 19.1 & 0.60 & 92.4 \\
18 & 6.73 & 20.1 & 19.3 & 0.61 & 98.7 \\
24 & 6.28 & 19.0 & 18.5 & 0.37 & 99.5 \\
\hline
\end{tabular}

${ }^{12}$ Influent or Effluent COD $(\mathrm{g} /$ day $)=\left(\operatorname{COD}\right.$ Measured $\left.\left(\frac{\mathrm{mg}}{\mathrm{L}}\right)\right)\left(\frac{1 \mathrm{~g} \text { COD }}{1000 \mathrm{mg} \mathrm{COD}}\right)\left(\frac{1 \mathrm{~L}}{\mathrm{HRT}(\mathrm{hr})}\right)\left(\frac{24 \mathrm{hr}}{\text { day }}\right)$

${ }^{13} \mathrm{H}_{2} \operatorname{COD}(\mathrm{g} /$ day $)=\left(\right.$ Vol. $\mathrm{H}_{2}$ Yield $\left.\left(\frac{\mathrm{LH}_{2}}{\mathrm{~L} \text {-day }}\right)\right)(1$-L liquid volume $)\left(\frac{1}{0.08206 \mathrm{~L} \text {-atm/mol- } \mathrm{K}}\right)\left(\frac{1 \mathrm{~atm}}{293 \mathrm{~K})}\right)\left(\frac{16 \mathrm{~g} \mathrm{COD}}{\mathrm{mol} \mathrm{H}}\right)$

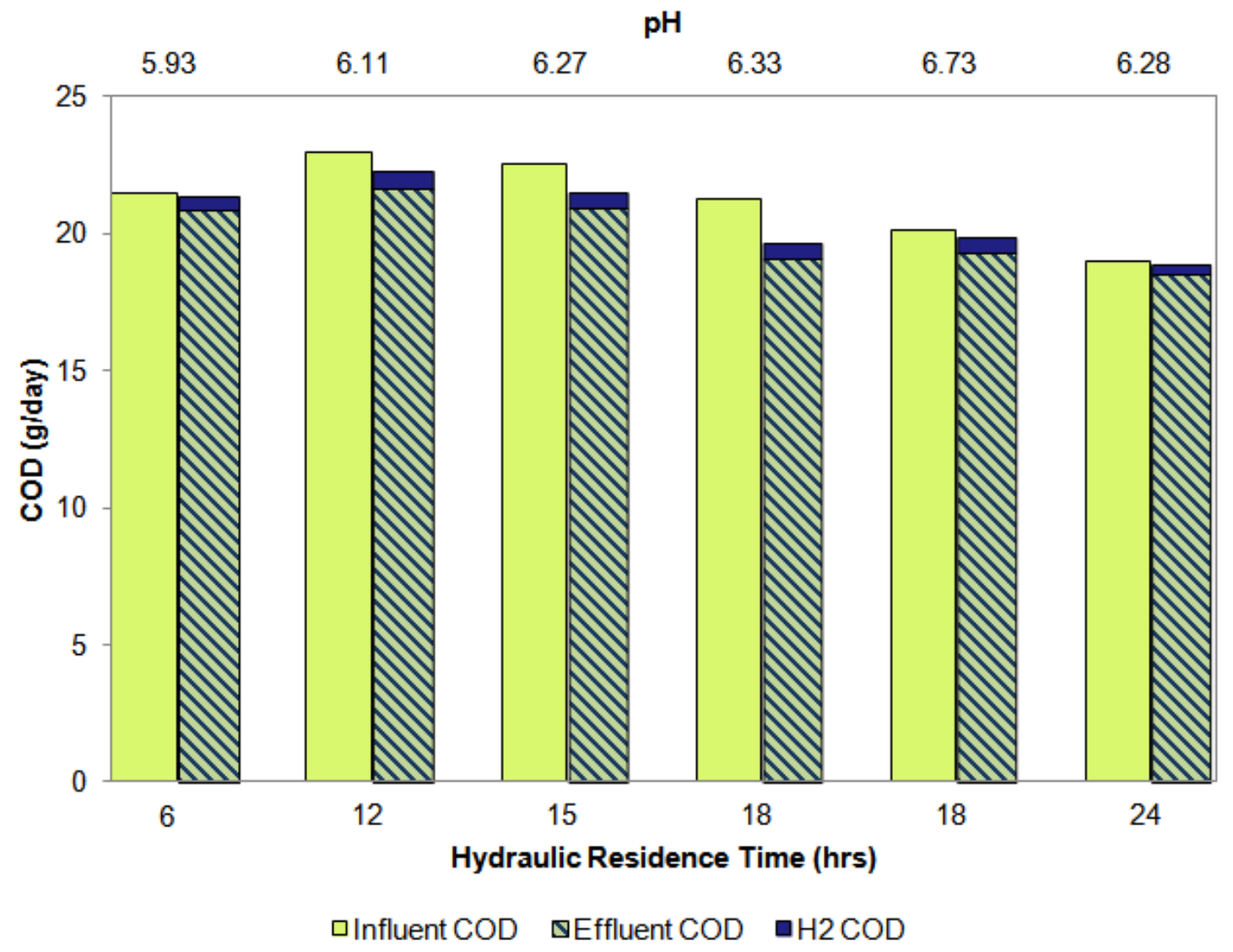

Figure 4-11: COD balance at all hydraulic residence times (HRTs) tested. 


\subsubsection{Discussion}

Results from the HRT experiment are discussed in the paragraphs below.

The 18-hr HRT was operated twice at $\mathrm{pH} 6.33$ and $\mathrm{pH}$ 6.73. In both cases, the volumetric, glucose-destroyed, COD-destroyed, and COD-introduced $\mathrm{H}_{2}$ yields were about the same. However, the glucose-introduced yield for the 18-hr HRT operated at $\mathrm{pH} 6.73$ was lower than the one operated at $\mathrm{pH} 6.33$. The glucose fed to 18-hr HRT ( $\mathrm{pH}$ 6.73) was about $4 \mathrm{~g} / \mathrm{L}$ higher than the 18-hr HRT (pH 6.33), so comparing glucose-introduced yields is not appropriate. Nevertheless, because the 18-hr HRT had similar $\mathrm{H}_{2}$ yields regardless of which $\mathrm{pH}$ it was operated at, this suggests $\mathrm{pH}$ has little influence on results and it is not as important to strictly control it as long as the $\mathrm{pH}$ is not very acidic $(\mathrm{pH}>6.0$, maybe lower).

The steady-state pHs for all HRTs tested did not vary greatly compared to the OLR experiment, which had pHs ranging from $4.4-6.4$. This occurred because OLR likely has more of an effect on $\mathrm{pH}$ than HRT. Because OLR was kept constant for the HRT experiment, as the HRT increased or decreased, the amount of glucose added increase or decreased proportionally. Thus, in any given time-period, the same amount of glucose was fed to the digesters. VFA formation, which causes $\mathrm{pH}$ to drop, uses glucose as a reactant, so the same amount of VFAs were probably produced in the digesters regardless of the HRT tested, causing less variation in $\mathrm{pH}$. 
Similar to the OLR experiment, COD destruction was less than $11 \%$ at all HRTs tested as most of the consumed glucose was converted to VFAs in the digester liquor. The actual COD destruction is likely lower because attached growth COD was unaccounted for.

\subsubsection{Ideal Operating HRT}

The goal of this experiment was to determine the HRT that maximized hydrogen yields in the first-phase digesters, which appeared to be $12 \mathrm{hrs}$ when operated at $22.9 \mathrm{~g} \mathrm{COD/L-day} \mathrm{(Table} \mathrm{4-18).} \mathrm{At} \mathrm{a} \mathrm{12-hr} \mathrm{HRT,} \mathrm{volumetric} \mathrm{H}_{2}$ yield and COD $\mathrm{H}_{2}$ yields (on a destroyed and introduced basis) were maximized. The 12-hr HRT had the third highest glucose-consumed and second-highest glucose-introduced $\mathrm{H}_{2}$ yields, but glucose measurements were not as reliable as COD measurements.

Because the 12-hr HRT had the highest $\mathrm{H}_{2}$ yields overall, it was chosen as the ideal operating HRT for the $1^{\text {st }}$-phase when operated at $22.9 \mathrm{~g} \mathrm{COD/L-day.}$

Table 4-18: $\mathrm{H}_{2}$ yield summary for the ideal HRT of $12 \mathrm{hrs}$ compared to other HRTs tested (within $\mathrm{pH} 5.0-6.5$ ).

\begin{tabular}{|c|c|c|c|c|}
\hline \multirow{2}{*}{$\begin{array}{c}\text { Volumetric } \\
\mathrm{H}_{2} \text { Yield } \\
\text { (L } \mathrm{H}_{2} / \\
\text { L-day) }\end{array}$} & \multicolumn{2}{|c|}{$\begin{array}{c}\text { Molar } \mathrm{H}_{2} \text { Yield (Glucose) } \\
\text { (mol } \mathrm{H}_{2} / \text { mol glucose) }\end{array}$} & \multicolumn{2}{|c|}{$\begin{array}{l}\text { Molar } \mathrm{H}_{2} \text { Yield (COD) } \\
\text { (mol H } \mathrm{H}_{2} / \text { mol COD) }\end{array}$} \\
\hline & $\begin{array}{c}\text { Per mol glucose } \\
\text { consumed }\end{array}$ & $\begin{array}{c}\text { Per mol glucose } \\
\text { introduced }\end{array}$ & $\begin{array}{l}\text { Per mol COD } \\
\text { destroyed }\end{array}$ & $\begin{array}{l}\text { Per mol COD } \\
\text { introduced }\end{array}$ \\
\hline $1.02 \pm 0.13$ & $0.61 \pm 0.10$ & $0.42 \pm 0.06$ & $1.06 \pm 0.16$ & $0.06 \pm 0.01$ \\
\hline Maximized & 3rd Highest & 2nd Highest & Maximized & $\begin{array}{l}\text { At Max } \\
\text { Threshold }\end{array}$ \\
\hline
\end{tabular}




\subsection{D Surface Model Summary}

3D surface-models of $\mathrm{HRT}$ vs. OLR vs. $\mathrm{H}_{2}$ yield within a $\mathrm{pH}$ range of $5.0-6.5$ were generated using data from the OLR/HRT experiments (Figure 4-12, Figure

\section{4-13, Figure 4-14, Figure 4-15, Figure 4-16, all on next pages).}

The $\mathrm{H}_{2}$ yields on the graphs do not always occur at the same operating conditions or have identical values to the ones experimentally determined. This occurred because the software extrapolates the data and does not take into account standard deviation. Also, the model must have leeway on some points so it can be practically used for estimating $\mathrm{H}_{2}$ yields at different operating conditions (i.e. an $R^{2}=100$ polynomial with all tested points fitting perfectly could be generated, but would be useless for estimating $\mathrm{H}_{2}$ yields at other data points). Therefore, some of the data points in the models are above or below the surface, which is indicated with a black line. 


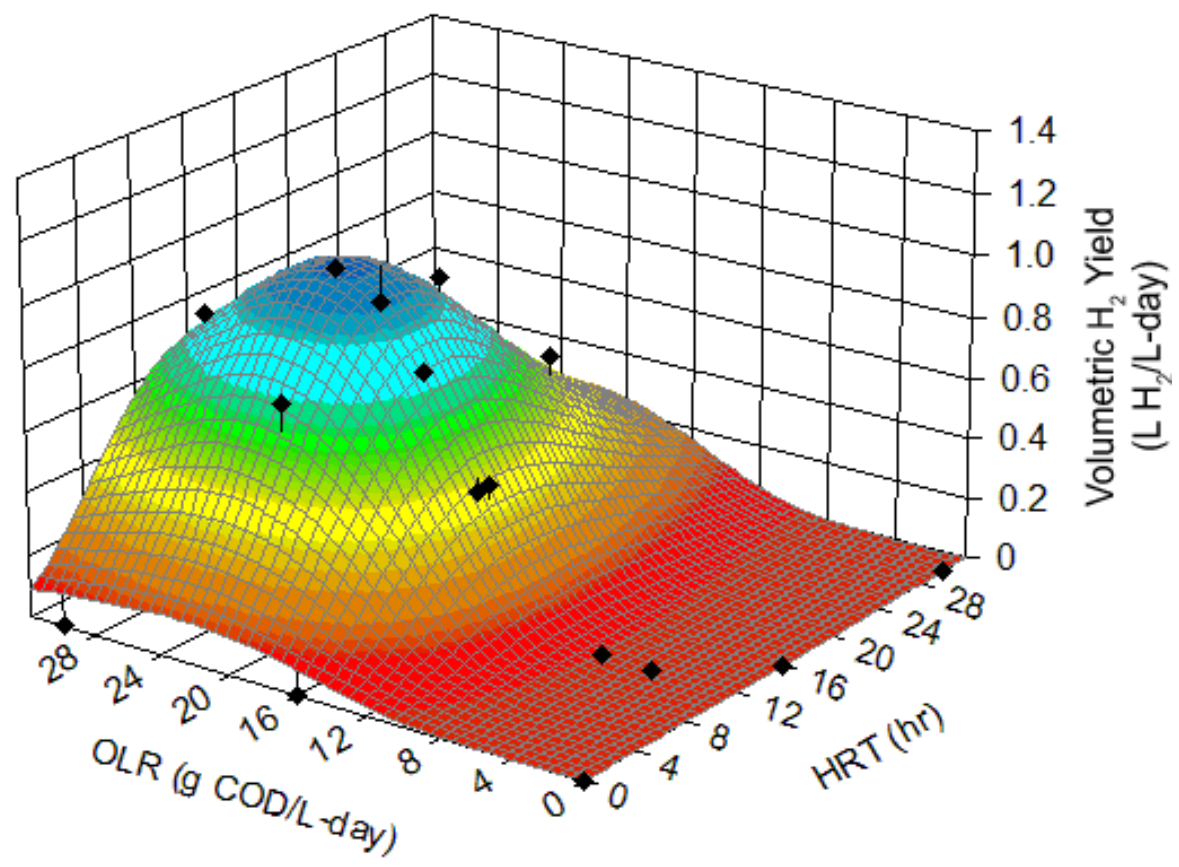

Figure 4-12: Volumetric $\mathrm{H}_{2}$ Yield vs. HRT vs. OLR (within $\mathrm{pH} 5.0$ - 6.5). This surface model predicts a maximum volumetric $\mathrm{H}_{2}$ yield of $1.02 \mathrm{~L} \mathrm{H}_{2} / \mathrm{L}$-day at a 13.0-hr HRT and an OLR of $23.2 \mathrm{~g} \mathrm{COD/L-day.}$

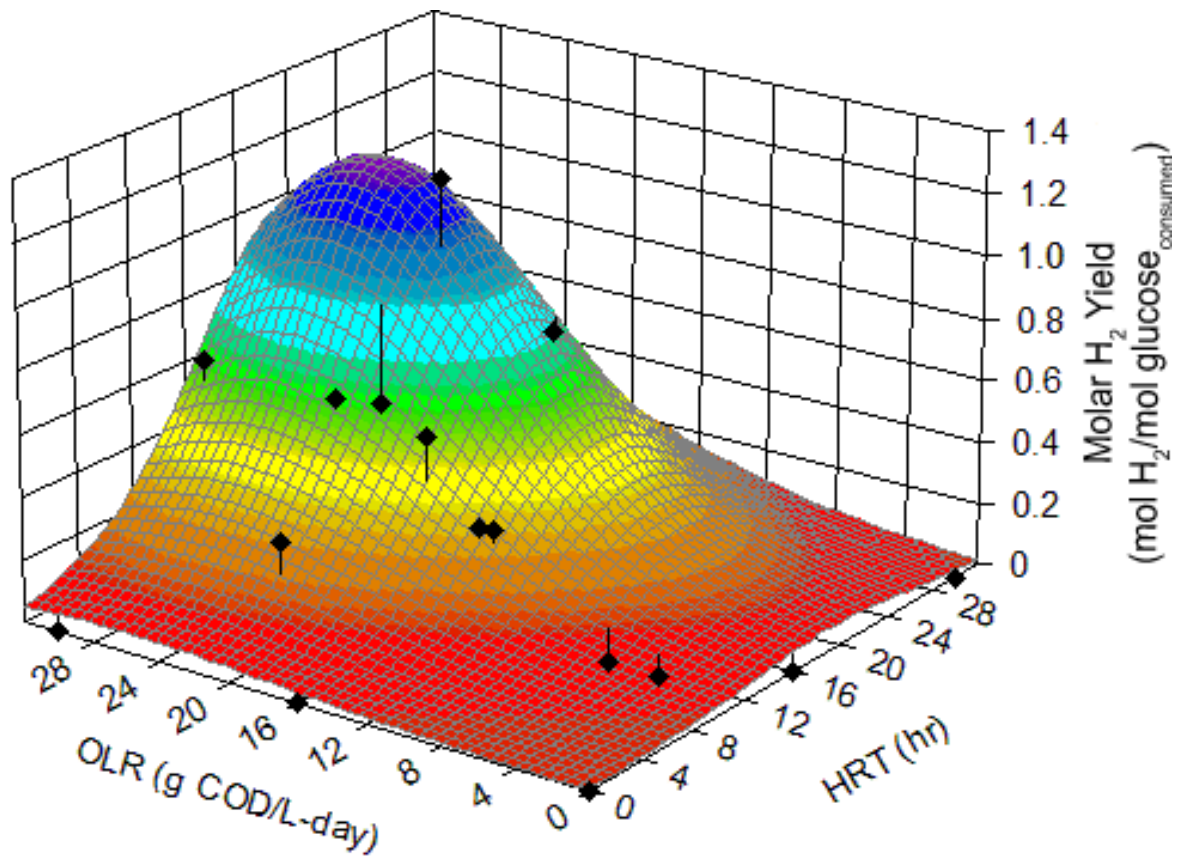

Figure 4-13: Glucose-consumed $\mathrm{H}_{2}$ Yield vs. HRT vs. OLR (within $\mathrm{pH} 5.0$ - 6.5). This surface model predicts a maximum glucose-consumed $\mathrm{H}_{2}$ yield of $1.20 \mathrm{~mol} \mathrm{H}_{2} / \mathrm{mol}$ glucose $_{\text {consumed }}$ at a 19.6-hr HRT and an OLR of $26.1 \mathrm{~g} \mathrm{COD/L-day.}$ 


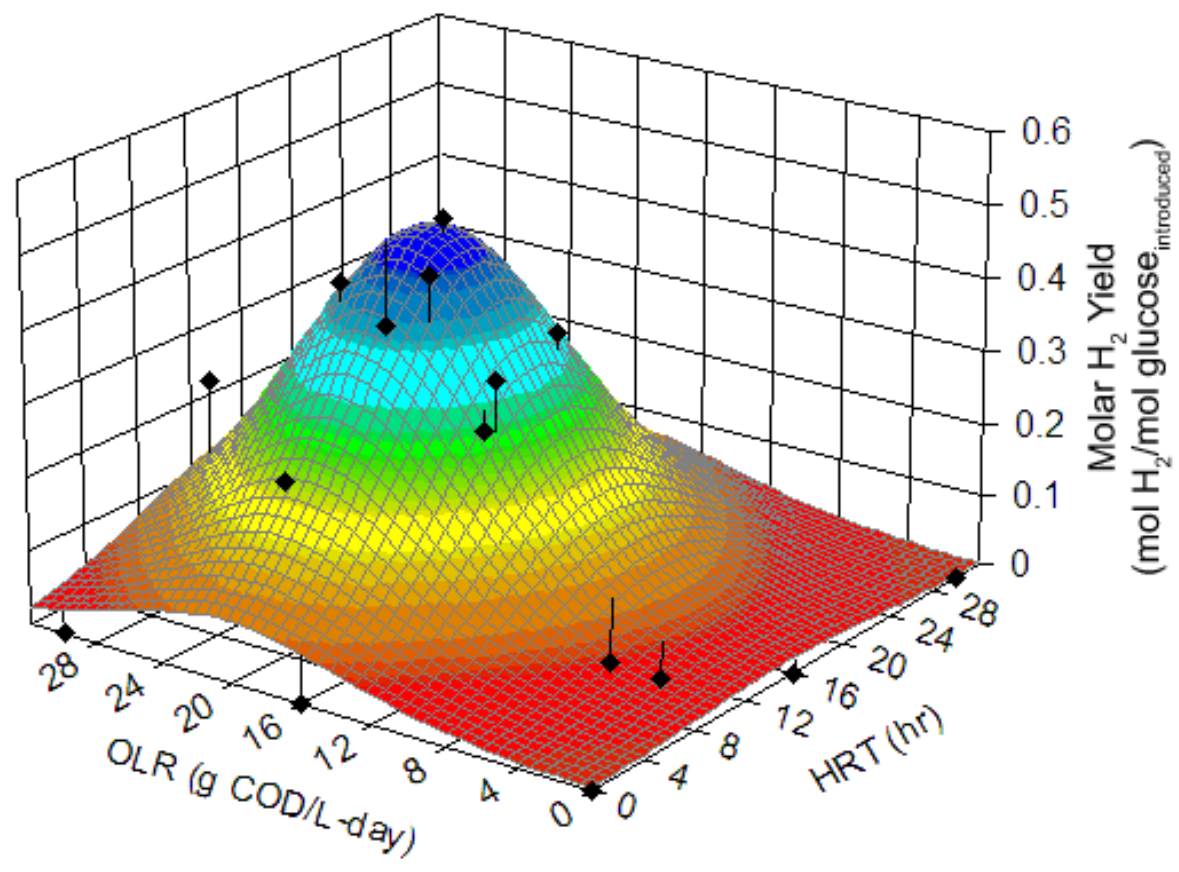

Figure 4-14: Glucose-introduced $\mathrm{H}_{2}$ Yield vs. HRT vs. OLR (within $\mathrm{pH} 5.0$ - 6.5). This surface model predicts a maximum glucose-introduced $\mathrm{H}_{2}$ yield of $0.48 \mathrm{~mol} \mathrm{H}_{2} / \mathrm{mol}$ glucose $_{\text {introduced }}$ at a 15.6-hr HRT and an OLR of $20.3 \mathrm{~g} \mathrm{COD/L-day.}$

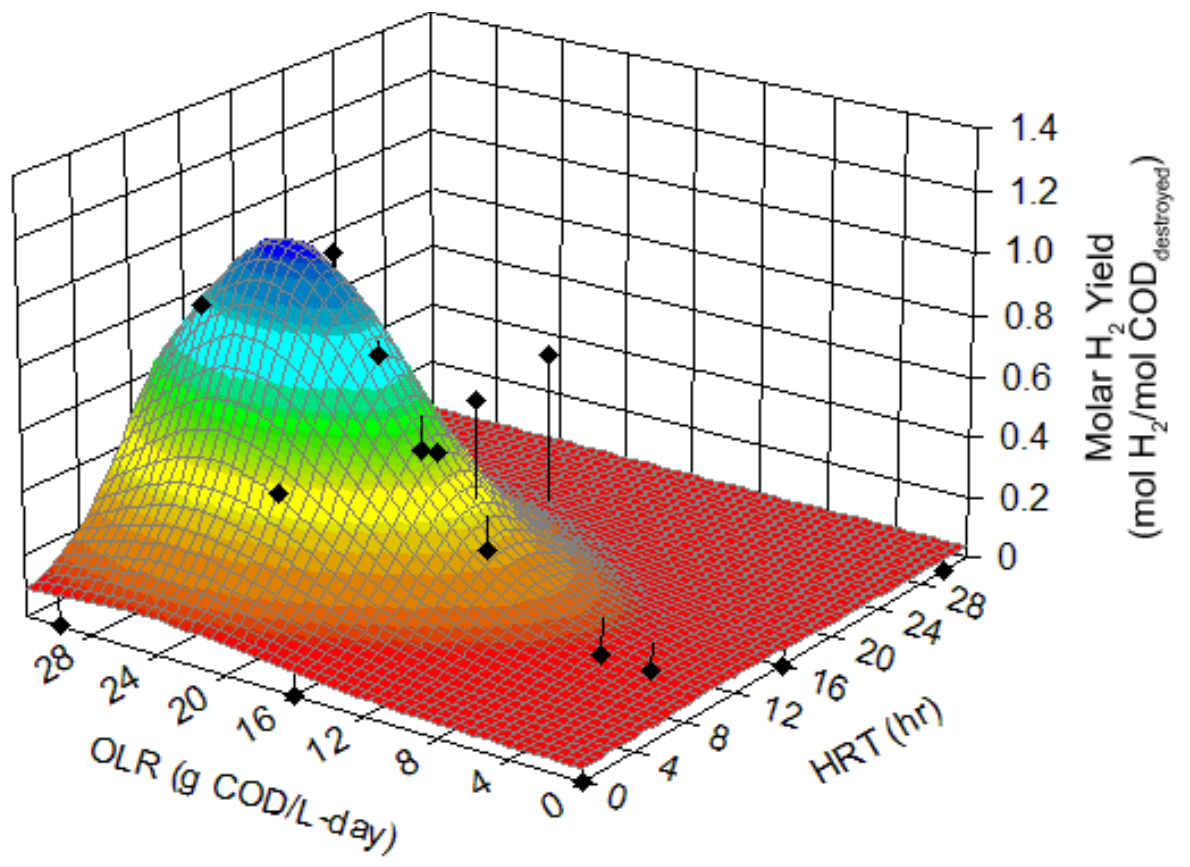

Figure 4-15: $\mathrm{COD}$-destroyed $\mathrm{H}_{2}$ Yield vs. HRT vs. OLR (within $\mathrm{pH} 5.0-6.5$ ). This surface model predicts a maximum COD-destroyed $\mathrm{H}_{2}$ yield of $1.08 \mathrm{~mol} \mathrm{H}_{2} / \mathrm{mol}$ $\mathrm{COD}_{\text {destroyed }}$ at an 11.6-hr HRT and an OLR of $25.2 \mathrm{~g} \mathrm{COD/L-day.}$ 


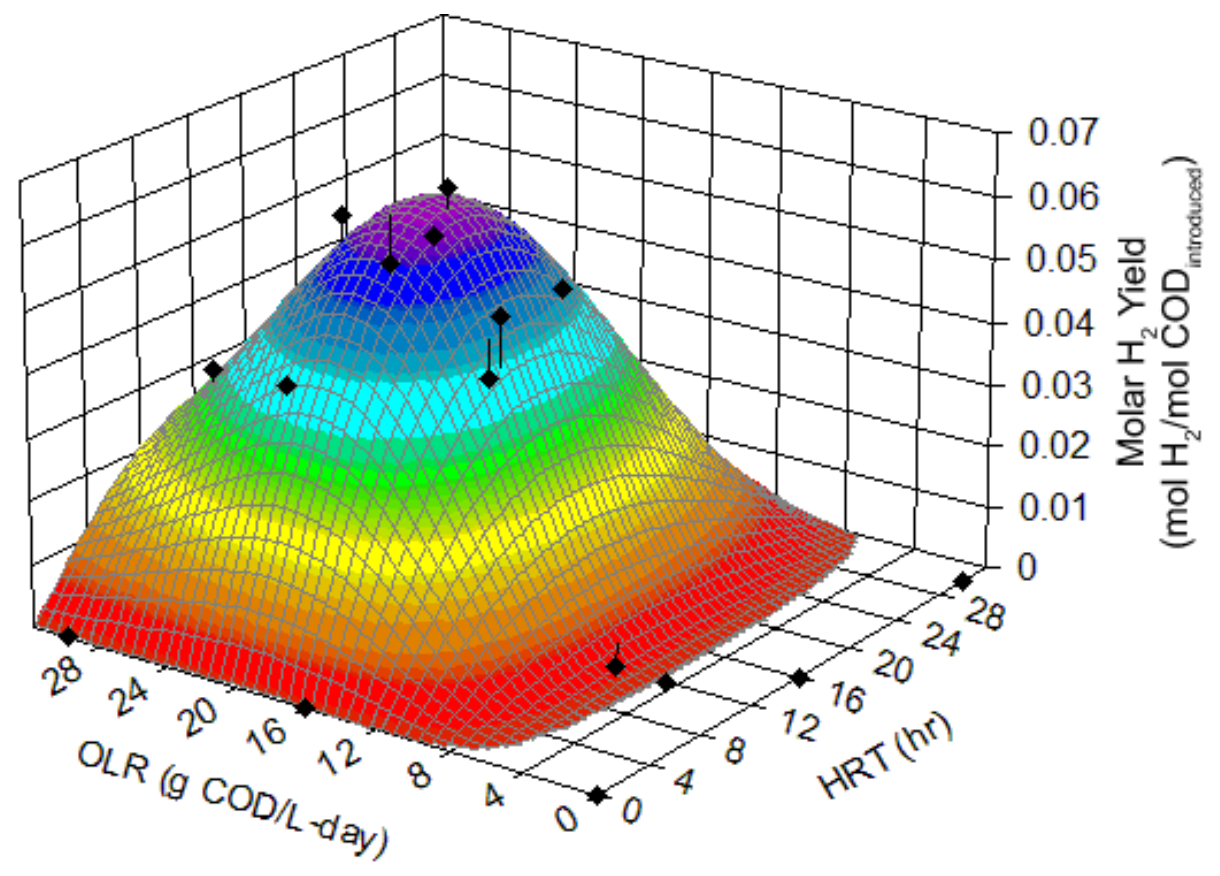

Figure 4-16: COD-introduced $\mathrm{H}_{2}$ Yield vs. HRT vs. OLR (within $\mathrm{pH} 5.0-6.5$ ). This surface model predicts a maximum COD-introduced $\mathrm{H}_{2}$ yield of $0.06 \mathrm{~mol} \mathrm{H}_{2} / \mathrm{mol}$ $\mathrm{COD}_{\text {introduced }}$ at a 14.0-hr HRT and an OLR of $19.5 \mathrm{~g} \mathrm{COD/L-day.}$

The peak values for all types of $\mathrm{H}_{2}$ yields clearly do not occur at the same OLR and HRT (Table 4-19), but the ideal operating conditions to maximize all yields are similar to those experimentally determined. From the previous experiments, an HRT of 12-hrs and OLR of $22.9 \mathrm{~g} \mathrm{COD/L-day} \mathrm{optimized} \mathrm{H}_{2}$ production. Based on the surface models, it was calculated an HRT of 15-hrs and OLR of $22.9 \mathrm{~g}$ COD/L-day was optimal (Table 4-19 - bottom row). These operating conditions agree closely and verify the $1^{\text {st }}$-phase experimental conclusions (that a 12 -hr $\mathrm{HRT}$ and OLR of $22.9 \mathrm{~g}$ COD/L-day is optimal for $\mathrm{H}_{2}$ production) are scientifically plausible. 
Table 4-19: Maximum theoretical $\mathrm{H}_{2}$ yield values predicted by the 3D surface models and their corresponding operating conditions.

\begin{tabular}{cccc}
\hline $\begin{array}{c}\text { Name of } \\
\mathbf{H}_{\mathbf{2}} \text { Yield }\end{array}$ & $\begin{array}{c}\text { Max Yield Value Predicted } \\
\text { By 3D Surface Model }\end{array}$ & $\begin{array}{c}\text { HRT } \\
\mathbf{( h r )}\end{array}$ & $\begin{array}{c}\text { OLR } \\
\text { (g COD/L-day) }\end{array}$ \\
\hline Volumetric & $1.02 \mathrm{~L} \mathrm{H}_{2} /$ L-day & 13.0 & 23.2 \\
Glucose-Consumed & $1.20 \mathrm{~mol} \mathrm{H}_{2} / \mathrm{mol}_{\text {glucose }}$ consumed & 19.6 & 26.1 \\
Glucose-Introduced & $0.48 \mathrm{~mol} \mathrm{H}_{2} / \mathrm{mol}_{\text {glucose }}$ introduced & 15.6 & 20.3 \\
COD-Destroyed & $1.08 \mathrm{~mol} \mathrm{H}_{2} / \mathrm{mol} \mathrm{COD}_{\text {destroyed }}$ & 11.6 & 25.2 \\
COD-Introduced & $0.06 \mathrm{~mol} \mathrm{H}_{2} / \mathrm{mol} \mathrm{COD}_{\text {introduced }}$ & 14.0 & 19.5 \\
\hline & $\begin{array}{c}\text { Average Value Calculated } \\
\text { (Best Operating Conditions) }\end{array}$ & 14.8 & 22.9 \\
\hline
\end{tabular}




\section{CHAPTER 5: NITROGEN SPARGING \& INTEGRATED FIRST AND SECOND-PHASE EXPERIMENTS}

The goal of the nitrogen sparging experiment was to determine which sparging rate achieved 15:85 $\mathrm{H}_{2}: \mathrm{CH}_{4}$ in the biogas. Once this was determined, the $1^{\text {st }}$ and second-phases were operated together at this target sparging rate to prove 15:85 $\mathrm{H}_{2}: \mathrm{CH}_{4}$ could be achieved.

The operational procedures, setup, and results of these experiments are discussed in this chapter.

\subsection{Nitrogen Sparging Experiment}

The objectives of this experiment were to determine the ideal flow rate of gas to sparge through the first-phase digesters to achieve: (1) higher $\mathrm{H}_{2}$ yields and (2) achieve near 15:85 $\mathrm{H}_{2}: \mathrm{CH}_{4}$. This was done by testing a wide range of sparging rates ( $1-30 \mathrm{~L} \mathrm{~N} / \mathrm{L}-\mathrm{hr}$ ) and analyzing the $\mathrm{H}_{2}$ yields and $\mathrm{H}_{2}$ biogas composition. $A$ 2D-model of $\mathrm{H}_{2}$ composition versus sparging rate was created to estimate the sparging rate required to achieve $15: 85 \mathrm{H}_{2}: \mathrm{CH}_{4}$.

The procedures and results of this experiment are discussed below.

\subsubsection{Experimental Procedures}

Before conducting this experiment, a new set of $1^{\text {st }}$-phase digesters were operated at the ideal operating conditions determined in the OLR and HRT experiments (22.9 g COD/L-day, 12-hr HRT) to ensure similar yields were achieved before sparging. Once this was accomplished, the $1^{\text {st }}$-phase digesters were sparged with $\mathrm{N}_{2}$. 
Sparging rates ranging from $1-30 \mathrm{~L} \mathrm{~N} / \mathrm{L}-\mathrm{hr}$ were tested (Note: The $L$ in the denominator represents the liquid volume of the $1^{\text {st }}$-phase, which in this case is 1-L). High sparging rates of 26.0 and $10.7 \mathrm{~L} \mathrm{~N} / \mathrm{L}-\mathrm{hr}$ (measured by gas meters) were tested to determine the maximum achievable $\mathrm{H}_{2}$ yields with sparging. A low-sparging flow rate of $1.0 \mathrm{~L} \mathrm{~N} / \mathrm{L}$-hr was tested as this value was more likely to be attained by a second-phase digester.

The $\mathrm{H}_{2}$ yield and biogas composition results obtained from all sparging rates were compared to those obtained for a zero-sparging rate (i.e. "no sparging"). The "no sparging" results are the same ones obtained for the $1^{\text {st }}$-phase digesters operated at $22.9 \mathrm{~g} \mathrm{COD} / \mathrm{L}$-day and 12-hr HRT from the $1^{\text {st }}$-phase optimization experiments.

\subsubsection{Organic Loading Rate and $\mathrm{pH}$}

OLR was calculated and $\mathrm{pH}$ was measured at all sparging rates (Table 5-1). The OLR at all sparging rates tested was between $22.7 \pm 1.4 \mathrm{~g} \mathrm{COD/L-day.} \mathrm{The} \mathrm{pH}$ at all sparging rates tested was between $6.0-6.4$.

The target OLR was $22.9 \mathrm{~g} \mathrm{COD/L-day.} \mathrm{Ideally,} \mathrm{the} \mathrm{pH}$ would be 6.11 as the ideal first-phase conditions were operated at this $\mathrm{pH}$, but because the $\mathrm{pH}$ could not be completely controlled it was acceptable for the sparged digesters to have a slightly different $\mathrm{pH}$. 
Table 5-1: Organic loading rates (OLRs) and $\mathrm{pHs}$ at all sparging rates tested. The target OLR was $22.9 \mathrm{~g} \mathrm{COD/L-day.}$

\begin{tabular}{ccc}
\hline $\begin{array}{c}\text { Sparging Rate } \\
\text { (L N } \mathbf{~}_{2} / \text { L-hr) }\end{array}$ & $\begin{array}{c}\text { OLR } \\
\text { (g COD/L-day) }\end{array}$ & pH \\
\hline No Sparging & 22.9 & 6.11 \\
1.0 & 22.6 & 6.06 \\
10.7 & 24.1 & 6.12 \\
26.0 & 21.5 & 6.31 \\
\hline
\end{tabular}

\subsubsection{Volumetric Hydrogen Yields}

Sparging significantly increased volumetric yields at all sparging rates tested. At

$1.0 \mathrm{~L} \mathrm{~N}_{2} / \mathrm{L}-\mathrm{hr}$, the volumetric $\mathrm{H}_{2}$ yield was $2.29 \pm 0.43 \mathrm{~L} \mathrm{H}_{2} / \mathrm{L}$-day, a $225 \%$

increase compared to the $1.02 \pm 0.13 \mathrm{~L} \mathrm{H}_{2} / \mathrm{L}$-day obtained without sparging for the OLR/HRT experiments. At the 10.7 and $26.0 \mathrm{~L} \mathrm{~N}_{2} / \mathrm{L}-\mathrm{hr}$ flow rates, volumetric yields were higher at $6.42 \pm 1.37 \mathrm{~L} \mathrm{H}_{2 /} \mathrm{L}$-day and $4.96 \pm 1.54 \mathrm{~L} \mathrm{H}_{2} / \mathrm{L}$-day, respectively (Figure 5-1).

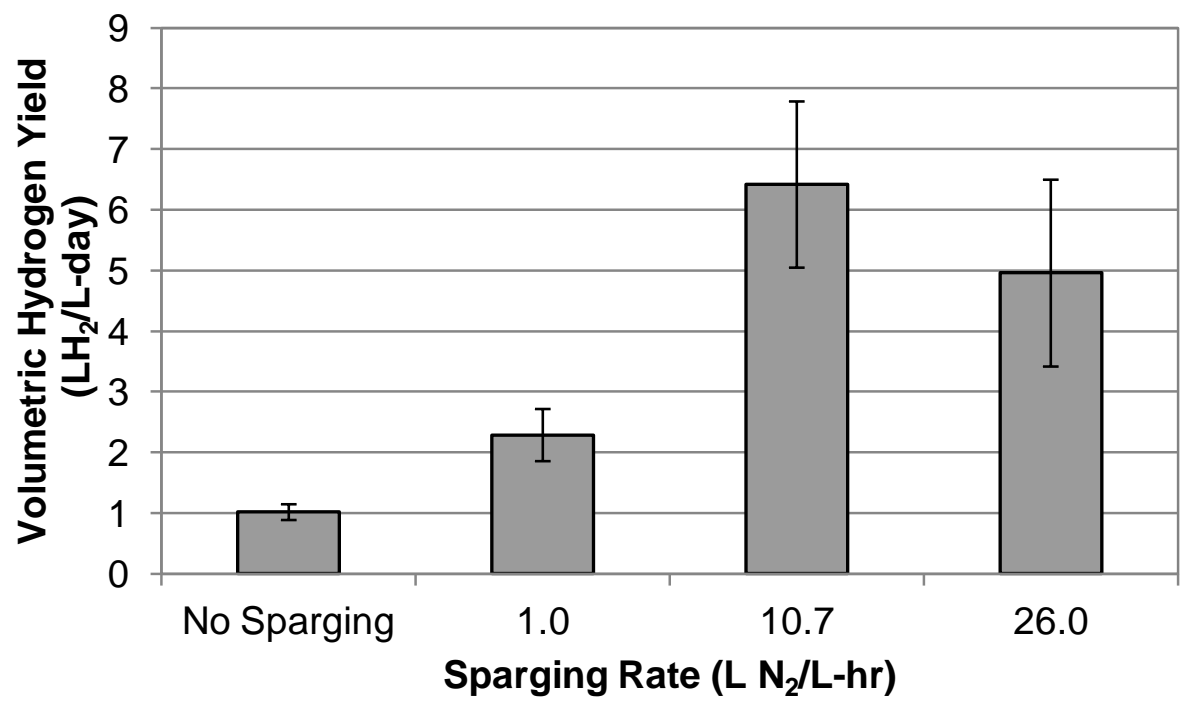

Figure 5-1: Volumetric $\mathrm{H}_{2}$ yields measured at all sparging rates tested. 


\subsubsection{Glucose Consumption}

Essentially $100 \%$ glucose consumption occurred at all sparging rates tested, compared to $68.9 \%$ glucose consumption with no sparging (Table 5-2).

The influent glucose values for sparged digesters varied greatly (average of 7.21 $+1.80 \mathrm{~g} / \mathrm{L})$. However, the \% glucose consumption values are likely correct because effectively all of the glucose was consumed regardless of the influent glucose concentration.

Table 5-2: Influent (feedstock) glucose, effluent glucose, glucose consumed, and \% glucose consumption at all sparging rates tested. Data from "no sparging" (same as 22.9 g COD/L-day, 12-hr HRT) is included for comparison.

\begin{tabular}{ccccc}
\hline $\begin{array}{c}\text { Sparging Rate } \\
(\mathbf{L ~ N} / \mathbf{L}-\mathbf{h r})\end{array}$ & $\begin{array}{c}\text { Influent } \\
\text { Glucose } \\
(\mathbf{g} / \mathbf{L})\end{array}$ & $\begin{array}{c}\text { Effluent } \\
\text { Glucose } \\
(\mathbf{g} / \mathbf{L})\end{array}$ & $\begin{array}{c}\text { Glucose }_{\text {Consumed }}{ }^{2} \\
(\mathbf{g} / \mathbf{L})\end{array}$ & $\begin{array}{c}\text { \% Glucose } \\
\text { Consumed }\end{array}$ \\
\hline No Sparging & $8.98 \pm 0.40$ & $2.79 \pm 1.04$ & 6.19 & 68.9 \\
1.0 & $8.95 \pm 1.20$ & $0.08 \pm 0.06$ & 8.87 & 99.2 \\
10.7 & $7.53 \pm 0.02$ & $0.07 \pm 0.12$ & 7.46 & 99.1 \\
26.0 & $5.34 \pm 2.93$ & $0.04 \pm 0.02$ & 5.30 & 99.3 \\
\hline
\end{tabular}

\subsubsection{Glucose-Consumed \& Glucose-Introduced Hydrogen Yields}

Glucose-consumption $\mathrm{H}_{2}$ yields increased at all sparging rates tested compared to the yield obtained without sparging $\left(0.61 \pm 0.10 \mathrm{~mol} \mathrm{H}_{2} / \mathrm{mol}\right.$ glucose $\left.\mathrm{consumed}\right) . \mathrm{H}_{2}$ yields of $0.97 \pm 0.19,3.08 \pm 0.85$, and $4.26 \pm 2.23 \mathrm{~mol} \mathrm{H}_{2} / \mathrm{mol}$ glucose $\mathrm{consumed}$ were calculated at 1.0, 10.7, and 26.0 L N $/ 2$-hr, respectively (Figure 5-2).

Glucose-introduced $\mathrm{H}_{2}$ yields closely matched glucose-consumption yields at all sparging rates tested as glucose consumption was essentially 100\% (Figure 5-2). 


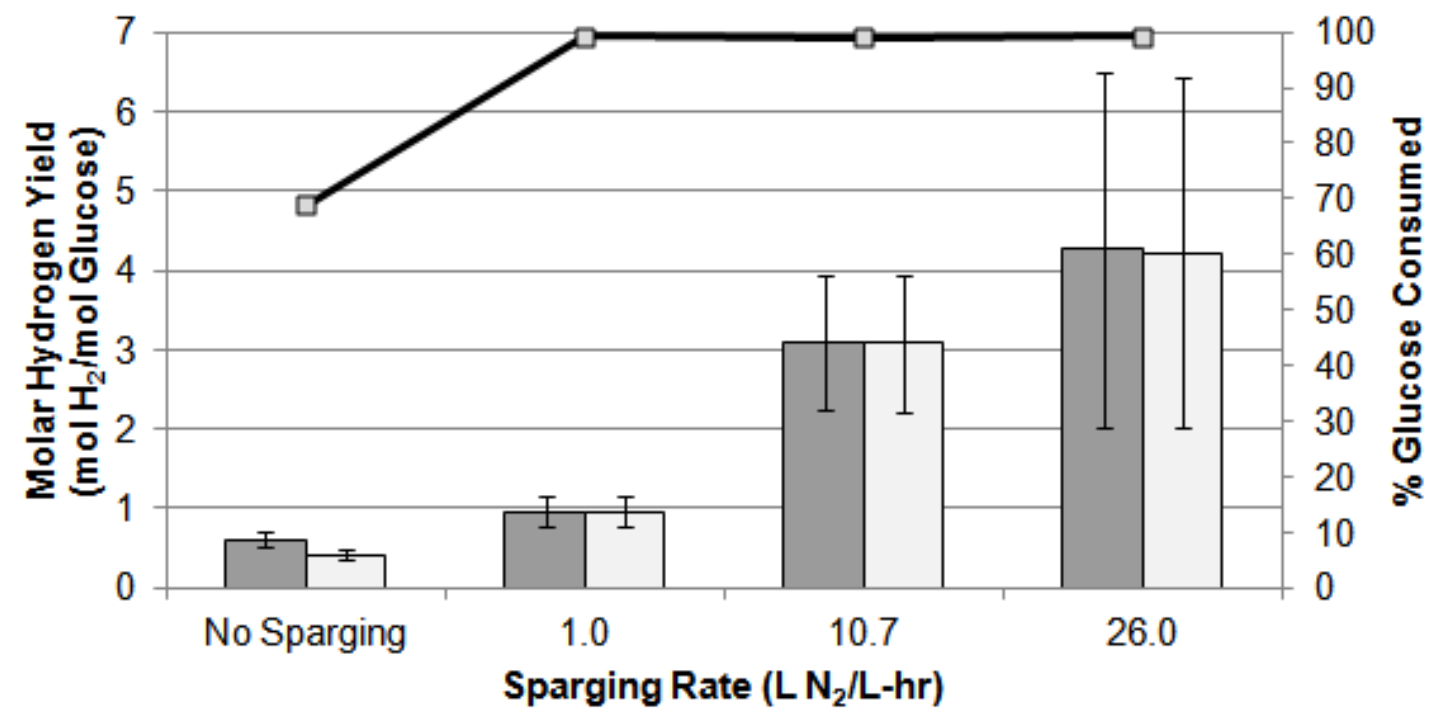

$\checkmark$ Yield (per mol glucose consumed) $\square$ Yield (per mol glucose introduced)

$\rightarrow \square \%$ Glucose Consumed

Figure 5-2: $\mathrm{H}_{2}$ yields on a glucose-consumed and glucose-introduced basis, and percent glucose consumed (for reference) at all sparging rates tested.

\subsubsection{COD Destruction}

The amount of COD destroyed was less than $19 \%$ at all sparging rates tested

(Table 5-3).

Table 5-3: Influent (feedstock) COD, effluent COD, and \% COD destruction at all sparging rates tested.

\begin{tabular}{cccc}
\hline $\begin{array}{c}\text { Sparging Rate } \\
\left(\mathbf{L ~ N} \mathbf{N}_{\mathbf{2}} / \mathbf{L}-\mathbf{h r}\right)\end{array}$ & $\begin{array}{c}\text { Influent COD } \\
\mathbf{( g / L} \mathbf{L})\end{array}$ & $\begin{array}{c}\text { Effluent COD } \\
\mathbf{( g / L )}\end{array}$ & $\begin{array}{c}\text { \% COD } \\
\text { Destroyed }\end{array}$ \\
\hline No Sparging & $11470 \pm 92$ & $10799 \pm 151$ & 5.9 \\
1.0 & $11314 \pm 358$ & $10192 \pm 262$ & 9.9 \\
10.7 & $12044 \pm 1464$ & $9798 \pm 491$ & 18.6 \\
26.0 & $10732 \pm 358$ & $9482 \pm 491$ & 11.7 \\
\hline
\end{tabular}

5.1.7 COD-Destruction \& COD-Introduced Hydrogen Yields

On a COD-destroyed basis, $\mathrm{H}_{2}$ yields increased at all sparging rates tested compared to the yield obtained without sparging $\left(1.06 \pm 0.16 \mathrm{~mol} \mathrm{H}_{2} / \mathrm{mol}\right.$ $\left.\mathrm{COD}_{\text {destroyed }}\right) . \mathrm{H}_{2}$ yields of $1.53 \pm 0.52,2.37 \pm 1.26$, and $3.26 \pm 2.46 \mathrm{~mol} \mathrm{H} / \mathrm{mol}$ 
$\mathrm{COD}_{\text {destroyed }}$ were calculated at 1.0,10.7, and $26.0 \mathrm{~L} \mathrm{~N} / \mathrm{L}$-hr, respectively (Figure $5-3)$.

On a COD-introduced basis, $\mathrm{H}_{2}$ yields were lowest without sparging $(0.06 \pm 0.01$ mol $\mathrm{H}_{2} / \mathrm{mol} \mathrm{COD}_{\text {introduced }}$ ) and increased to $0.14 \pm 0.03$ with sparging at $1.0 \mathrm{~L}$ $\mathrm{N}_{2} / \mathrm{L}$-hr. The COD-introduced $\mathrm{H}_{2}$ yields at higher yields of 10.7 and 26.0 L N2/Lhr were similar at $0.35 \pm 0.06 \mathrm{~mol} \mathrm{H}_{2} / \mathrm{mol} \mathrm{COD}_{\text {introduced }}$ and $0.31 \pm 0.10 \mathrm{~mol}$ $\mathrm{H}_{2} /$ mol COD $D_{\text {introduced, }}$, respectively (Figure 5-3).

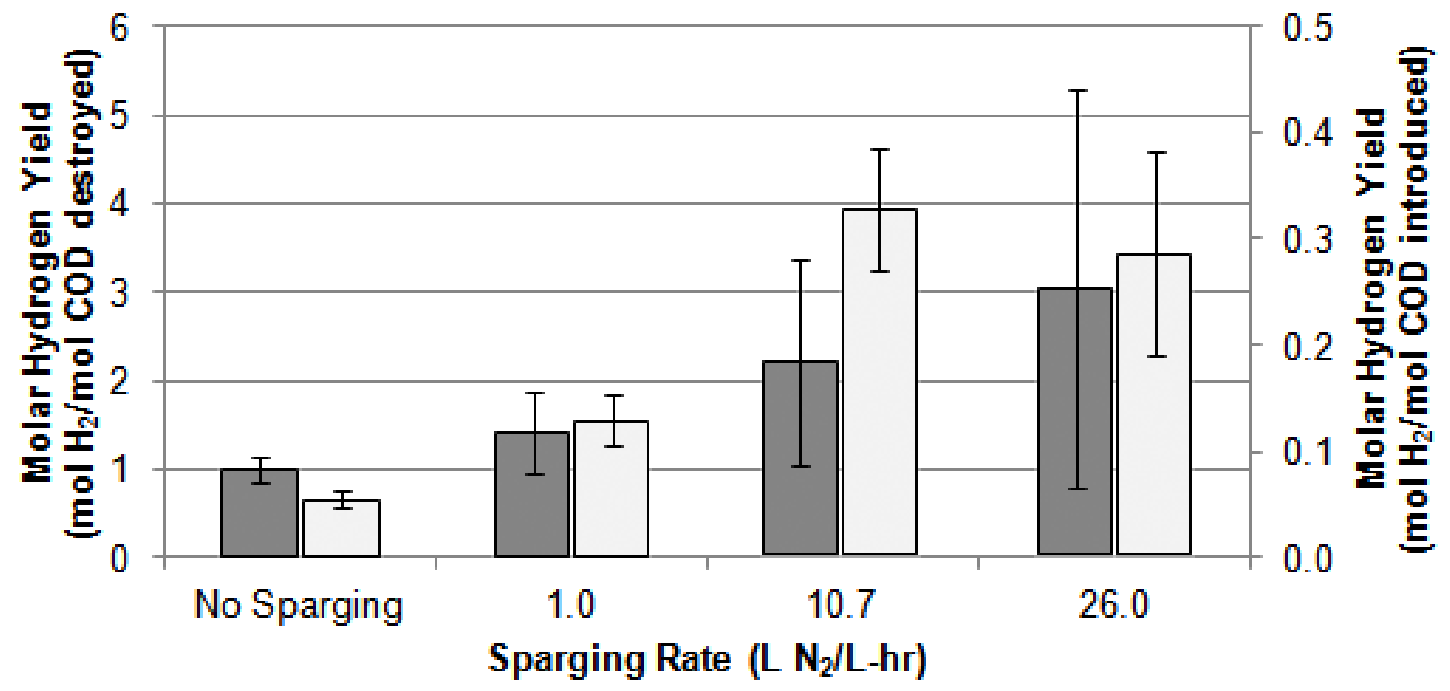

口COD Destroyed Basis $\quad$ aCOD Introduced Basis

Figure 5-3: $\mathrm{H}_{2}$ yields on a COD-destroyed and COD-introduced basis at all sparging rates tested. 


\subsubsection{Chemical Oxygen Demand (COD) Balance}

A COD balance was calculated and recoveries were within $96-104 \%$ for all sparging rates tested (Table 5-4 \& Figure 5-4).

Table 5-4: COD Balance for all sparging rates tested. Percent (\%) recovery was calculated as $\left(\frac{\text { Effluent } \mathrm{COD}+\mathrm{H}_{2} \text { COD Measured }}{\text { Influent } \mathrm{COD}}\right) \times 100 \%$.

\begin{tabular}{|c|c|c|c|c|}
\hline $\begin{array}{l}\text { Sparging } \\
\text { Rate } \\
\left.\text { (L N } N_{2} / L-h r\right)\end{array}$ & $\begin{array}{c}\text { Influent } \\
\text { COD }^{14} \\
\text { (g/day) }\end{array}$ & $\begin{array}{l}\text { Effluent } \\
\text { COD }^{14} \\
\text { (g/day) }\end{array}$ & $\begin{array}{c}\mathrm{H}_{2} \text { COD } \\
\text { Calculated }^{15} \\
\text { (g/day) }^{15}\end{array}$ & $\begin{array}{c}\% \\
\text { Recovery }\end{array}$ \\
\hline 1.0 & 22.63 & 20.38 & 1.53 & 96.8 \\
\hline 10.6 & 24.09 & 19.59 & 4.28 & 99.1 \\
\hline 26.0 & 21.46 & 18.96 & 3.30 & 103.7 \\
\hline
\end{tabular}

${ }^{14}$ Influent or Effluent COD $(\mathrm{g} /$ day $)=\left(\operatorname{COD}\right.$ Measured $\left.\left(\frac{\mathrm{mg}}{\mathrm{L}}\right)\right)\left(\frac{1 \mathrm{~g} \operatorname{COD}}{1000 \mathrm{mg} \operatorname{COD}}\right)\left(\frac{1 \mathrm{~L}}{\mathrm{HRT}(\mathrm{hr} r}\right)\left(\frac{24 \mathrm{hr}}{\text { day }}\right)$

${ }^{15} \mathrm{H}_{2} \operatorname{COD}(\mathrm{g} /$ day $)=\left(\right.$ Vol. $\mathrm{H}_{2}$ Yield $\left.\left(\frac{\mathrm{LH}_{2}}{\mathrm{~L} \text {-day }}\right)\right)(1$-L liquid volume $)\left(\frac{1}{0.08206 \mathrm{~L} \text {-atm/mol-K }}\right)\left(\frac{1 \mathrm{~atm}}{293 \mathrm{~K})}\right)\left(\frac{16 \mathrm{~g} \mathrm{COD}}{\mathrm{mol} \mathrm{H}_{2}}\right)$

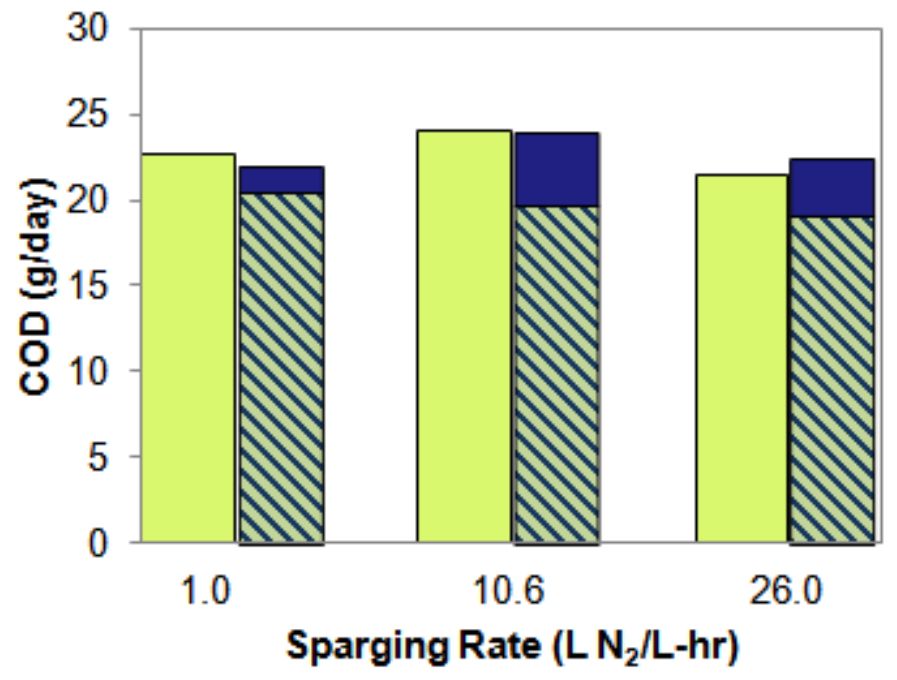

Influent COD बEffluent COD $\quad \mathbf{H} 2 \mathrm{COD}$

Figure 5-4: COD balance at all sparging rates tested. 


\subsubsection{Mixed Gas Composition}

As sparging rate increased, biogas $\mathrm{H}_{2}$ composition decreased due to dilution.

The remaining constituents in the biogas were $\mathrm{N}_{2}$ and $\mathrm{CO}_{2}$. Because $\mathrm{N}_{2}$ was used to simulate the second-phase biogas, it was assumed to consist of $60 \%$

$\mathrm{CH}_{4}$ and $40 \% \mathrm{CO}_{2}$ (typical for a $\mathrm{CH}_{4}$-producing digester). With this correction, the $\mathrm{H}_{2}: \mathrm{CH}_{4}$ ratios estimated for the $1.0,10.6$, and $26.0 \mathrm{~L} \mathrm{~N} / \mathrm{L}-\mathrm{hr}$ sparging rates were $15: 83,15: 354$, and $15: 1083$, respectively (Table 5-5).

Table 5-5: Measured $\mathrm{H}_{2}, \mathrm{CO}_{2}$, and $\mathrm{N}_{2}$ biogas compositions at all sparging rates tested. Estimated mixed gas compositions and $\mathrm{H}_{2}: \mathrm{CH}_{4}$ ratios are also shown.

\begin{tabular}{|c|c|c|c|c|c|c|c|}
\hline \multirow{2}{*}{$\begin{array}{l}\text { Sparging } \\
\text { Rate } \\
\text { (L N } \mathrm{N}_{2} / \mathrm{L}-\mathrm{hr} \text { ) }\end{array}$} & \multicolumn{3}{|c|}{$\begin{array}{c}\text { Actual Phase } 1 \text { Biogas } \\
\text { Composition }\end{array}$} & \multicolumn{4}{|c|}{$\begin{array}{c}\text { Estimated Mixed Gas } \\
\text { Composition }^{*}\end{array}$} \\
\hline & $\% \mathrm{H}_{2}$ & $\% \mathrm{CO}_{2}$ & $\% \mathrm{~N}_{2}$ & $\% \mathrm{H}_{2}$ & $\% \mathrm{CH}_{4}$ & $\% \mathrm{CO}_{2}$ & $\mathrm{H}_{2}: \mathrm{CH}_{4}$ \\
\hline 1.0 & 8.6 & 11.8 & 79. & 8.6 & 47.8 & 43.6 & $15: 83$ \\
\hline 10.6 & 2.4 & 3.2 & 94 & 2.4 & 56. & 41 & $15: 354$ \\
\hline 26.0 & 0.8 & 2.9 & 96.3 & 0.8 & 57.8 & 41.4 & $15: 1083$ \\
\hline
\end{tabular}

${ }^{*}$ Calculated by assuming $\mathrm{N}_{2}$ consisted of $60 \% \mathrm{CH}_{4}, 40 \% \mathrm{CO}_{2}$.

\subsubsection{Hydrogen Composition Prediction Model}

Sparging rate and $\% \mathrm{H}_{2}$ were graphed to estimate the sparging rate required for a $15: 85 \mathrm{H}_{2}: \mathrm{CH}_{4}$ ratio (Figure 5-5). A power function with the equation $\mathrm{y}=9.3 x^{-0.7}$, where $x=$ sparging rate $\left(L N_{2} / L-h r\right)$ and $y=\% H_{2}$, was fitted to the data and had an $R^{2}$ of 0.99 . Using this function, at a flow rate of $1.1 \mathrm{~L}$ gas $/ \mathrm{L}-\mathrm{hr}$, a hydrogen percentage of $8.7 \%$ was expected, which corresponded to $15 \mathrm{H}_{2}: 85 \mathrm{CH}_{4}$ if the rest of the gas is assumed to have a biogas composition comparable to the $1.0 \mathrm{~L}$ gas/L-hr experiment. 


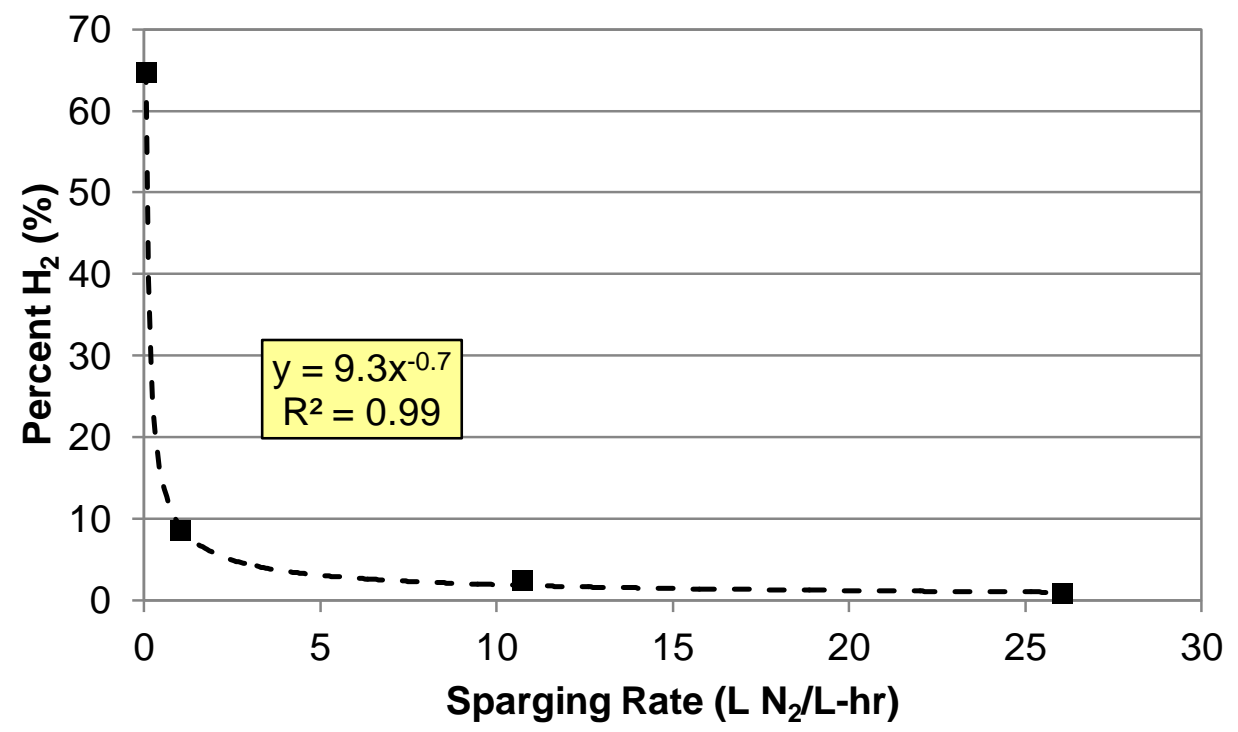

Figure 5-5: Actual sparging rate vs. measured $\% \mathrm{H}_{2}$ for the $\mathrm{N}_{2}$ sparging experiment.

\subsubsection{Discussion}

Sparging at any of the flow rates tested increased $\mathrm{H}_{2}$ yields as confirmed in other studies. A remarkable observance is with increasing sparging rate, the glucoseconsumption yield increased drastically, with the $26.0 \mathrm{~L} \mathrm{~N} \mathrm{~N}_{2} / \mathrm{L}-\mathrm{hr}$ flow rate achieving an $\mathrm{H}_{2}$ yield of $4.26 \pm 2.23 \mathrm{~mol} \mathrm{H}_{2} / \mathrm{mol}_{\text {glucose }}$ consumed. Although the standard error is high, this falls within the range of the theoretical maximum of 4 mol $\mathrm{H}_{2} / \mathrm{mol}$ glucose. This could be due to decreased $\mathrm{H}_{2}$ partial pressure as a result of sparging (Hallenbeck \& Benemann, 2002). Decreased $\mathrm{H}_{2}$ partial pressure makes acetate production more thermodynamically favorable, resulting in yields closer to $4 \mathrm{~mol} \mathrm{H}_{2} / \mathrm{mol}$ glucose (see Section 2.4.2).

Because the sparging model showed $1.1 \mathrm{~L}$ gas/L-hr could achieve $15: 85 \mathrm{H}_{2}: \mathrm{CH}_{4}$, this was the target sparging rate used for the integrated $1^{\text {st }}$ and $2^{\text {nd }}$ stage experiment. However, it should be noted that since there was only one data point 
( $1 \mathrm{~L} \mathrm{~N} \mathrm{~N}_{2} / \mathrm{L}-\mathrm{hr}$ ) tested near real conditions, the ideal sparging rate may not be completely accurate.

\subsection{Integrated First and Second-Phase Experiment}

Although two 20-L digesters were used to sparge gas into the first-phase, not enough gas was made to test the target $1.1 \mathrm{~L}$ gas/L-hr. Only enough gas was made to operate at a sparging rate of $0.28 \mathrm{~L}$ gas $/ \mathrm{L}-\mathrm{hr}$, which was estimated by subtracting the gas measured in Gas Meter B (control digester) from Gas Meter A (sparged digester) (Figure 5-6). Therefore, 15:85 $\mathrm{H}_{2}: \mathrm{CH}_{4}$ was unlikely to be achieved. Data was still collected at this low sparging rate and is analyzed in the following sections.

\subsubsection{Experimental Procedures}

For the integrated experiment, two 20-L FLPE digesters, each with a liquid volume of $20 \mathrm{~L}$, and HRT of 30 days, were seeded with sludge collected from the SLO WRRF. The second-phase digesters were operated for three months before connecting them to the first-phase. During this period, the second-phase digesters were manually fed effluent collected from first-phase experiments and the $\mathrm{pH}$ was controlled daily to keep the $\mathrm{pH}$ near 7.8. Alkalinity, gas production, TSS/VSS, and gas chromatography data were collected weekly.

Initially, it was planned to connect each second-phase digester to a separate first-phase digester. However, each second-phase digester on its own was not producing enough gas for sparging at the ideal rate found in the $\mathrm{N}_{2}$ sparging experiment. Therefore, each second-phase digester was fed effluent from a 
separate first-phase digester, but the gas from both second-phase digesters was combined and sparged into only one of the first-phase digesters. The nonsparged first-phase digester served as a control.

Because the first and second-phases were operated at different HRTs, a $500-\mathrm{mL}$ capacity, mixed surge tank (Nalgene bottle) was placed between the first and second-phase digesters to temporarily hold effluent before it entered the secondphase. Any excess effluent collected from the first-phase overflowed out of the surge tank and was wasted because feeding all of the first-phase effluent would have made the HRT in the second-phase too short. This indicated the secondphase needed to be larger (addressed in Section 6.3.4 - Recommendations).

The biogas generated from the sparged and control first-phase digesters were collected in a gas meter and analyzed via gas chromatography. Alkalinity, $\mathrm{pH}$, and COD were analyzed for all digesters once steady state was reached. TSS/VSS was also collected from the second-phase for COD balance calculations. 


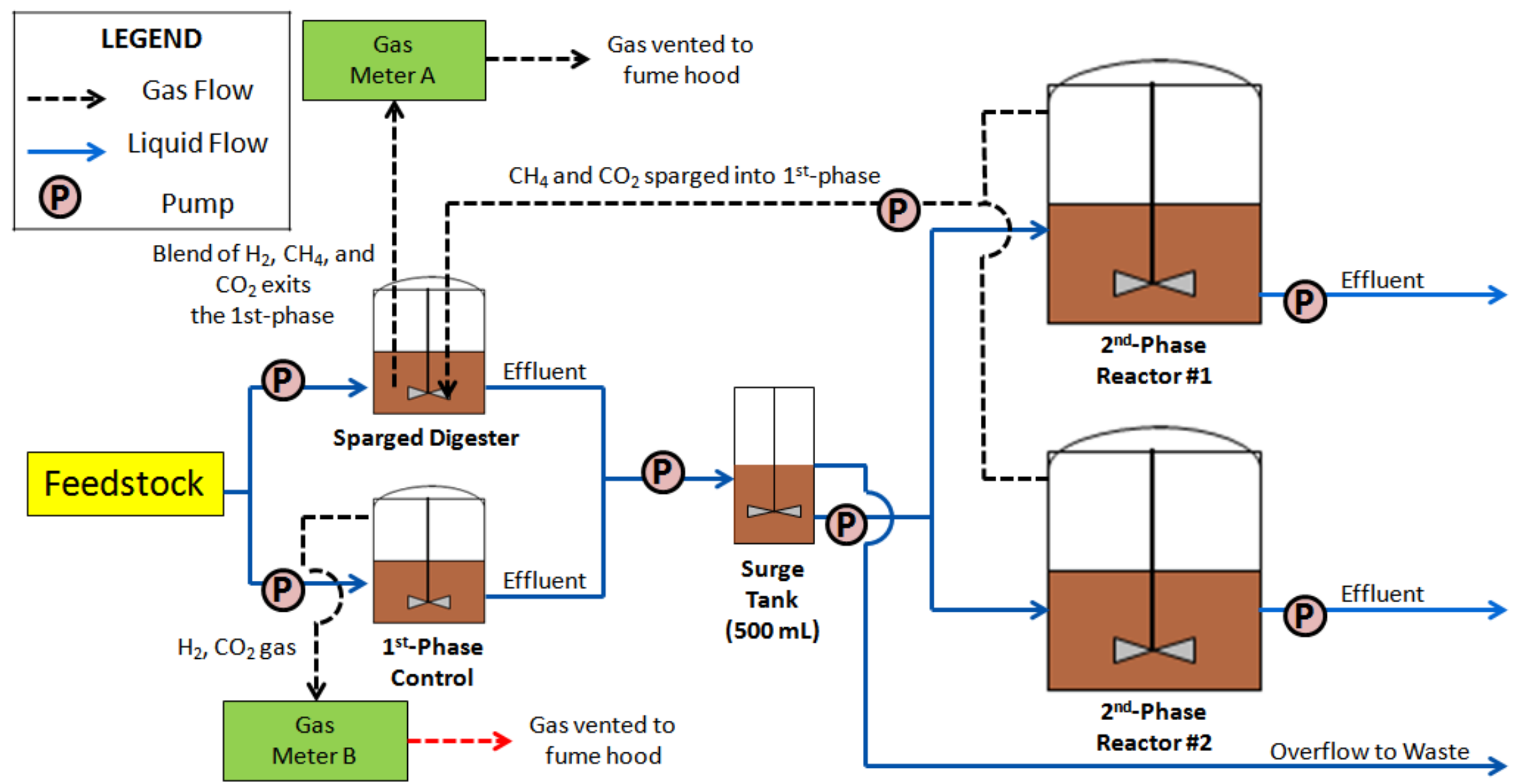

Figure 5-6: Schematic of the integrated first and second-phase experiment. 


\subsubsection{Results}

Only three-days of steady-state data were collected for this experiment due to difficulty in selecting a sparging rate $(0.28 \mathrm{~L}$ gas $/ \mathrm{L}-\mathrm{hr})$ that did not create a vacuum in the second-phase. The results (Table 5-6) are analyzed below.

The average pHs measured in the first-phase and second-phase were 5.71 and 6.84, respectively. The ideal $\mathrm{pH}$ for the first-phase was 6.11 (from OLR of $22.9 \mathrm{~g}$ COD/L-day at a 12-hr HRT), but the first-phase $\mathrm{pH}$ was lower. The sparged $\mathrm{CO}_{2}$ from the second-phase likely entered solution and caused the $\mathrm{pH}$ to be lowerthan-expected.

COD was measured for the first-phase and second-phase digesters. The firstphase influent (feedstock) COD was $10380 \mathrm{mg} \mathrm{COD/L}$, which is equivalent to a $20.8 \mathrm{~g} \mathrm{COD/L-day} \mathrm{OLR} \mathrm{(target} \mathrm{was} 22.9 \mathrm{~g}$ COD/L-day). The effluent COD from the first-phase was $10430 \mathrm{mg} / \mathrm{L}$, which is larger than the effluent COD, but this discrepancy could be due to these values being within the COD test's $\pm 7.5 \%$ accuracy error.

The difference between the influent and effluent COD in the second-phase was more pronounced than the first-phase. The influent COD was $10430 \mathrm{mg} / \mathrm{L}$ (same as first-phase effluent COD) and the effluent COD was $1220 \mathrm{mg} / \mathrm{L}$, which means $88.3 \%$ of COD was destroyed (VFAs are converted into $\mathrm{CH}_{4}$ in the secondphase).

Average biogas composition was measured for both phases. The biogas exiting the sparged $1^{\text {st }}$-phase digester had $25.5 \% \mathrm{H}_{2}, 20.0 \% \mathrm{CH}_{4}$, and $54.5 \% \mathrm{CO}_{2}$, 
which corresponds to an $\mathrm{H}_{2}: \mathrm{CH}_{4}$ of $15: 12$. The second-phase biogas consisted of $61.9 \% \mathrm{CH}_{4}$, and $38.2 \% \mathrm{CO}_{2}$.

Table 5-6: Data summary for the first and second-phases in the integrated experiment.

\begin{tabular}{rcccccccc}
\hline Phase & $\begin{array}{c}\text { Influent } \\
\mathbf{C O D} \\
(\mathbf{m g} / \mathbf{L})\end{array}$ & $\begin{array}{c}\text { Eff. }{ }^{*} \\
\mathbf{C O D} \\
(\mathbf{m g} / \mathbf{L})\end{array}$ & $\mathbf{p H}$ & $\% \mathrm{H}_{2}$ & $\% \mathrm{CH}_{4}$ & $\% \mathrm{CO}_{2}$ & $\begin{array}{c}\text { Sparge } \\
\text { Rate }\end{array}$ & $\mathbf{H}_{2}: \mathrm{CH}_{4}$ \\
\hline 1st & $10380^{* *}$ & $10430^{\star *}$ & 5.71 & 25.5 & 20.0 & 54.5 & $0.28 \mathrm{~L}$ & $15: 12$ \\
2nd & 10430 & 1220 & 6.84 & 0.0 & 61.9 & 38.2 & gas/L-hr & \\
\hline
\end{tabular}

*"Eff." stands for "effluent."
**These CODs were within the COD test's precision error of $\pm 7.5 \%$.

\subsubsection{Second-Phase COD Balance}

As not enough gas was made in the second-phase to sparge at $1.1 \mathrm{~L}$ gas $/ \mathrm{L}-\mathrm{hr}$, a COD balance was calculated and theoretical gas production was estimated to determine if the second-phase digesters were functioning normally.

From the COD-balance, the COD recovery was $84.5 \%$ for the second-phase, but could have been closer to $100 \%$ because this estimation was based on the volume of $\mathrm{CH}_{4}$ in the sparging gas, and not what was actually produced in the second-phase (Figure 5-7). 


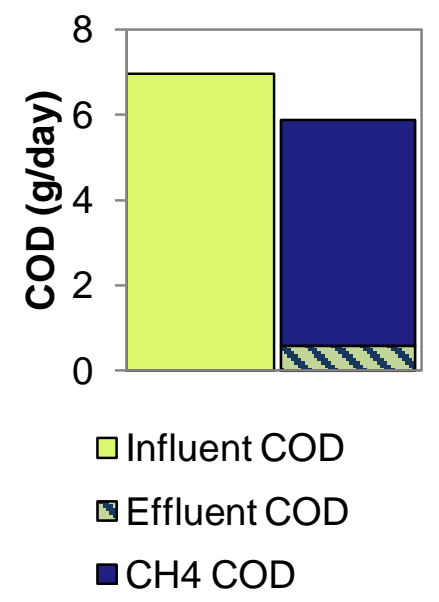

Figure 5-7: COD Balance for the second-phase digesters.

Theoretical gas production in the second-phase was estimated using COD data (see Appendix A for calculations). The theoretical gas production rate was $0.32 \mathrm{~L}$ gas/hr, compared to the sparging rate of $0.28 \mathrm{~L}$ gas $/ \mathrm{hr}$. The sparging rate was used for comparison because the gas from the second-phase was not measured directly. Thus, the actual gas produced in the second-phase was likely closer to the theoretical value as some non-sparged gas was unaccounted for.

\subsubsection{Discussion}

Results from the integrated experiment are discussed in the paragraphs below.

Gas production in the second-phase was too low to achieve the ideal sparging rate of $1.1 \mathrm{~L}$ gas $/ \mathrm{L}-\mathrm{hr}$ although the second-phase digesters were operating normally. The amount of gas generated in the second-phase could be increased by adding more substrate, but due to time constraints this solution was not performed. Thus, without any operational or reactor changes, an additional $120 \mathrm{~L}$ (160 L total) of suspended mix, second-phase digesters would be required to sparge enough gas to achieve 15:85 $\mathrm{H}_{2}: \mathrm{CH}_{4}$ in one 1-L first-phase digester. 
COD destruction in the second-phase was significantly higher (88\%) than the first-phase (not measurable). Because most of the COD in anaerobic digestion is converted into $\mathrm{CH}_{4}$, this explains why the $\mathrm{COD}$ destruction was high.

The sparging rate for this experiment was $0.28 \mathrm{~L}$ gas $/ \mathrm{L}-\mathrm{hr}$ and the $\% \mathrm{H}_{2}$ measured was $25.5 \%$, which was plugged into the nitrogen sparging model. At $0.28 \mathrm{~L}$ gas $/ \mathrm{L}-\mathrm{hr}, 22.3 \% \mathrm{H}_{2}$ was predicted by the nitrogen sparging model. The percent difference between the measured and predicted $\% \mathrm{H}_{2}$ at this sparging rate was $14.3 \%$, indicating the model was relatively accurate for predicting $\mathrm{H}_{2}$ composition at different sparging rates (Figure 5-8). Therefore, although the ideal sparging rate of $1.1 \mathrm{~L} / \mathrm{L}-\mathrm{hr}$ was not tested, it is still likely a sparging rate near this value can achieve the ideal $15: 85 \mathrm{H}_{2}: \mathrm{CH}_{4}$ ratio for the specific conditions used in this project.

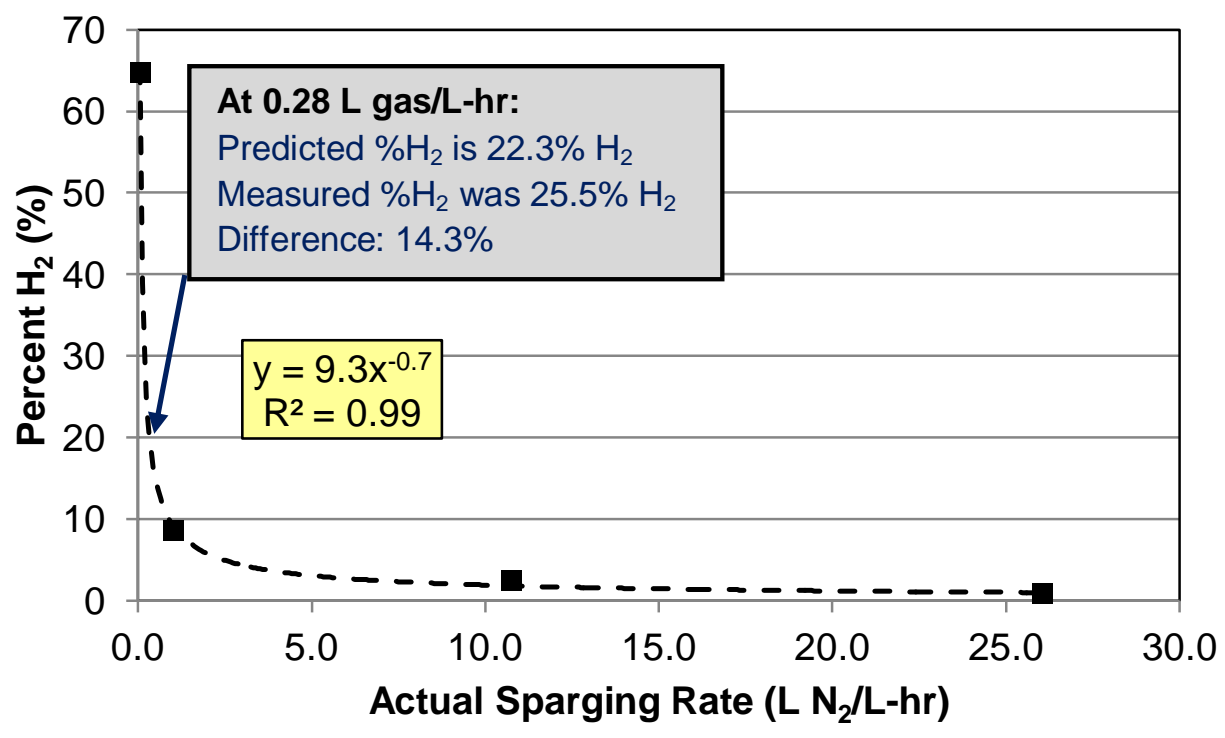

Figure 5-8: Measured and predicted $\% \mathrm{H}_{2}$ at a sparging rate of $0.28 \mathrm{~L}$ gas $/ \mathrm{L}-\mathrm{hr}$. 


\section{CHAPTER 6: CONCLUSIONS}

In this chapter, the optimal operating conditions from (1) first-phase optimization experiments, (2) $\mathrm{N}_{2}$ sparging experiments, and (3) integrated operation of the $1^{\text {st }}$ and second-phase to obtain a 15:85 $\mathrm{H}_{2}: \mathrm{CH}_{4}$ ratio are summarized. Research limitations and recommendations for future studies are also discussed.

\subsection{Experimental Conclusions}

The following experimental conclusions were made for each of this project's goals (italicized):

- Identify the HRT and OLR in the first-phase for optimizing hydrogen yields: An OLR of $22.9 \mathrm{~g} \mathrm{COD/L-day,} 12-\mathrm{hr} \mathrm{HRT}$, and $\mathrm{pH}$ of 6.11 optimized hydrogen yields in the first-phase (Table 4-18).

- Test different biogas sparging rates from the second-phase into the firstphase to develop a model of hydrogen composition versus sparging rate, and use this model to predict which sparging rate achieved 15:85 $\mathrm{H}_{2}: \mathrm{CH}_{4}$ : A sparging rate of $1.1 \mathrm{~L}$ gas $/ \mathrm{L}-\mathrm{hr}$ from the second-phase to the first-phase was estimated to obtain the ideal $15 \mathrm{H}_{2}: 85 \mathrm{CH}_{4}$ ratio.

- Integrate the first and second-phases using the optimal conditions identified from the first two objectives: A sparging rate of $0.28 \mathrm{~L}$ gas $/ \mathrm{L}-\mathrm{hr}$ could only be achieved for the integrated experiment. At this sparging rate, the $\mathrm{H}_{2}: \mathrm{CH}_{4}$ ratio was $15: 12$, yet the results agreed closely with the model used for predicting the optimal sparging rate was $1.1 \mathrm{~L}$ gas/L-hr. Therefore, a sparging rate near $1.1 \mathrm{~L}$ gas/L-hr could still potentially achieve 15:85 
$\mathrm{H}_{2}: \mathrm{CH}_{4}$ in the biogas for the specific operating conditions used in this project.

\subsection{Research Limitations}

A few limitations encountered and identified in this study were:

- The HRT of the first-phase (12 hrs) was significantly faster than the $2^{\text {nd }}$ phase (30 days), so a surge tank was required to temporarily store firstphase effluent. Excess first-phase effluent had to be wasted as the second-phase digesters could not accommodate all of it.

- Not enough biogas was produced in the second-phase to test the ideal sparging rate of $1.1 \mathrm{~L}$ gas $/ \mathrm{L}-\mathrm{hr}$ although it was operating normally. More biogas could have been produced by manually adding glucose into the second-phase, but this was not done due to time constraints.

- Attached growth (biofilm) was observed in all first-phase digesters. This presents a problem because methanogens can become attached and eventually dominate the first-phase. Although no methane was measured in the first-phase experiments, the operation time of the digesters was never longer than three weeks. Long term-operation of the digesters could potentially result in takeover of the first-phase by methanogens

- This was a proof-of-concept project, and thus, the ideal operating conditions identified in this study only apply to the specific experiment setup used. 
- The mixing speed was not the same for all experiments due to unintentionally using different types of stir plates. For first-phase optimization experiments, the stir plates had an RPM of around 1140. For the $N_{2}$ sparging and integrated experiments, the first-phase digesters were operated with stir plates at an RPM of approximately 700 .

- The mixing speeds tested in this experiment do not accurately reflect realistic operation of the first-phase. Mixing speeds would be lower due to the higher costs and technological limitations of mixing fast at full-scale.

\subsection{Recommendations}

Recommendations for future studies on (1) two-phase digestion and (2) hydrogen-methane mixtures for reducing NOx emissions in biogas will be discussed below.

\subsubsection{Attached Growth Research}

While it was assumed only suspended biomass occurred in the digesters, growth was observed on the walls and tubing, most likely originating as residue from the sludge inoculum (Figure 6-1). Therefore, methanogens may have been present in the first-phase because the SRT of the digesters was likely longer than the HRT due to biofilm growth. 

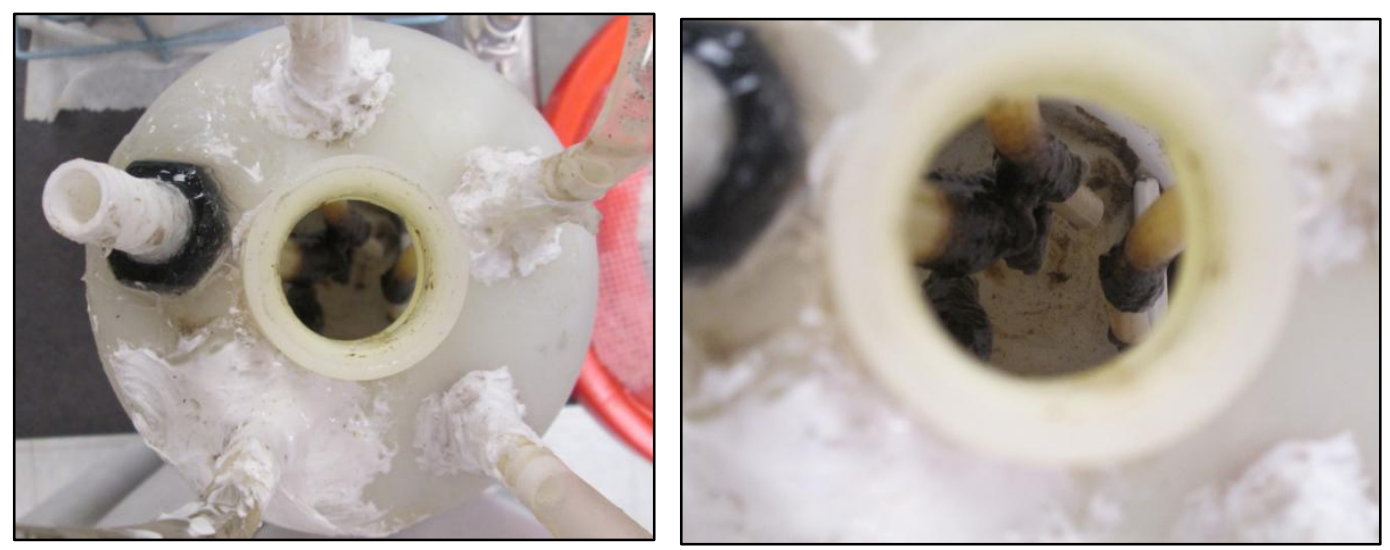

Figure 6-1: Attached growth occurred on the tubing in the inside of the digesters and the inner walls.

No methane was measured for all first-phase experiments that produced measurable amounts of gas. This could potentially be due to individual OLR/HRT experiments typically lasting no longer than three weeks. The low pHs (less than 6.5 in general) tested in the first-phase may have also suppressed methane production as methanogens prefer a $\mathrm{pH}$ range of $6.6-7.6$.

Some hydrogen fermentation studies observed no methane production even when operated for months, but these studies used heated and chemically-treated inoculum to eliminate methanogens (Chang, Lee, \& Lin, 2002; C. Y. Lin, Lee, Tseng, \& Shiao, 2006). Conversely, Fang and Liu used a non-treated, mixed culture inoculum and found that even at a 6 -hr HRT, methane production occurred at pHs above 6.0 (2002).

For future studies on two-phase digestion, it needs to be confirmed if methanogens are suppressed in the first-phase even with attached growth for long-term operation. 


\subsubsection{Practical Substrates for Hydrogen Production}

Glucose was used as the substrate in this experiment because it was easy to measure, readily consumed by bacteria, and numerous studies on producing hydrogen from glucose are available. However, for real-life applications, glucose is not practical as it needs to be purchased and the cost-benefit ratio would not justify anaerobically digesting it. More suitable substrates for producing hydrogen, preferably organic wastes such as food waste, corn stock waste or human waste, need to be studied for use in two-phase digestion.

Manure was not mentioned because a separate in-house study found manure is not able to produce hydrogen. As anaerobic digestion occurs in a cow's digestive system, the products left over (mainly VFAs) are not suitable for hydrogen production. Methane can still be produced from manure, but a different substrate needs to be digested to produce hydrogen in the first-phase (see Section 6.3.3).

\subsubsection{Digestion of Different Substrates in the First-Phase}

Because digested manure is capable of producing methane but not hydrogen, for application of two-phase digestion at a dairy farm, other cheap, practical substrates would need to be explored for use in the first-phase. Dairy farms that transport milk to creameries could potentially haul back creamery waste for use in the first-phase. Another potential substrate is glycerol, a waste product of biodiesel production (Donkin, Koser, White, Doane, \& Cecava, 2009). Glycerol is widely available and its price has recently dropped (Adhikari, Fernando, \& Haryanto, 2009), making it a substrate worth investing more research into. 


\subsubsection{Fixed Film Second-Phase Digesters}

Because the first-phase HRT (12 hrs) was much faster than the second-phase (30 days), the second-phase could not accommodate all of the first-phase effluent. As a result, first-phase effluent was discharged from the system via surge tanks.

For practical applications, all of the waste would need to be accommodated by the second-phase. Using fixed-film digesters instead of suspended growth digesters could potentially solve this problem. Fixed-film digesters are filled with media to promote attached growth, which effectively decouples the SRT from the HRT. Because fixed-film digesters retain more bacteria than suspended-growth digesters by volume, waste is degraded faster. This allows for fixed-film digesters to be operated at typical HRTs of 2-6 days and less volume than suspendedgrowth digesters (Wilkie, 2000).

\subsubsection{Digester Volume Ratio Optimization}

A major problem encountered in this project was not enough gas was produced in the second-phase digesters to sparge at the ideal rate of $1.1 \mathrm{~L} \mathrm{gas} / \mathrm{L}-\mathrm{hr}$. Although the first-phase to second-phase liquid to volume ratio was $1: 40$, this ratio would need to be at least 1:160 to attain the ideal sparging rate if no operational changes are made (e.g. operating the $1^{\text {st }}$-phase so less hydrogen is made and therefore less sparging gas is required to achieve $\left.15: 85 \mathrm{H}_{2}: \mathrm{CH}_{4}\right)$. As mentioned in Section 6.3.4, fixed-film second-phase digesters could potentially reduce the required volume so the first-to-second-phase volume ratio is substantially lower. 
Another option is to utilize an existing covered anaerobic lagoon as a secondphase digester, as the first-phase digester's volume could realistically be $1 / 160$ th of the lagoon's volume.

\subsubsection{Methane Reformation of Biogas to Hydrogen}

Biogas reformation could potentially be a simpler, more cost-effective approach to producing hydrogen-methane mixtures than two-phase digestion. Methane reformation is currently the most used commercial method for producing hydrogen (Holladay, Hu, King, \& Wang, 2009). However, raw biogas cannot be used in traditional reforming processes as catalysts can be poisoned by hydrogen sulfide present in the gas (Alves et al., 2013). Also, biogas with a $\mathrm{CH}_{4} / \mathrm{CO}_{2}$ ratio $>1$ causes coke formation and plugging of nickel-based catalysts (Effendi, Hellgardt, Zhang, \& Yoshida, 2005).

In all cases, $\mathrm{H}_{2} \mathrm{~S}$ needs to be removed from biogas to be used in any reforming process. This is similar to how biogas needs to be purified for acceptable use in an internal combustion engine. Additional research is needed to determine whether it is more financially feasible and easier to reform biogas from a conventional anaerobic digester into hydrogen than using two-phase digestion to produce hydrogen-methane mixtures.

\subsubsection{Effect of $\mathrm{CO}_{2}$ on Combustion Characteristics of $\mathrm{H}_{2} / \mathrm{CH}_{4}$ Blends}

The ideal 15:85 $\mathrm{H}_{2}: \mathrm{CH}_{4}$ ratio for reduced NOx emissions and optimal engine efficiency was determined from studies that used only hydrogen and methane. 
However, because $\mathrm{CO}_{2}$ is also present in the biogas, it could negatively affect the combustion characteristics of the gas.

One negative aspect of $\mathrm{CO}_{2}$ is that it cannot be burned with oxygen, lowering the heating value of the gas mixture. Also, biogas containing more than $40 \% \mathrm{CO}_{2}$ needs to be scrubbed to prevent poor engine performance (Bari, 1996), leading to increased costs. Yet, the presence of $\mathrm{CO}_{2}$ is not completely bad because less NOx emissions (but more hydrocarbons) are generated from combusting biogas containing $\mathrm{CO}_{2}$ than natural gas (mainly $\mathrm{CH}_{4}$ ) alone (Crookes, 2006).

Regardless, for biogas mixtures containing $\mathrm{H}_{2}-\mathrm{CH}_{4}$ mixtures for reduced NOx emissions, further research is needed to determine the effect $\mathrm{CO}_{2}$ has on combustion characteristics and pollutant emissions if it is present in the gas during combustion.

\subsubsection{Effect of Mixing on $\mathrm{H}_{2}$ Production}

For this study, high mixing speeds (700 and 1140 RPM) were used unintentionally. High mixing speeds lower the liquid-side hydrogen partial pressure (Cooney et al., 2007), increasing hydrogen production. For full-scale hydrogen-producing digesters, lower mixing speeds are expected (Cooney et al., 2007). Therefore, additional research on two-phase digestion using slower, more realistic mixing speeds is needed to better understand how this process would scale-up. 


\subsubsection{Lactic Acid Bacteria}

A similar two-phase digestion study that used non-treated inoculum had considerable amounts of lactate present, likely due to the presence of lactic acid bacteria, which consume substrate but do not produce hydrogen. As a result, this study had low $\mathrm{H}_{2}$ yields (Cooney et al., 2007). Because the feedstock and inlet lines had to replaced every two days due to visible bacterial contamination, and the mixing speeds were intentionally low (increasing the $\mathrm{H}_{2}$ partial pressure), lactic-acid bacteria were favored (Cooney et al., 2007).

For this thesis, visible contamination never occurred in the improved feedstock containers, and inlet tubing lines were cleaned occasionally (every 3-4 days) to discourage bacterial growth. Therefore, lactic acid bacteria may not have been as dominant in this project as the one performed by Cooney et al.

While lactic-acid bacteria did not seem to affect hydrogen production in this thesis, for future studies, it is important to ensure their growth is limited to prevent low $\mathrm{H}_{2}$ yields.

\subsubsection{Volatile Fatty Acid Testing}

VFAs were not tested for this project, but for future studies it is recommended to test for these components as the relative amounts of acetic and butyric acid directly relate to bacterial metabolism and hydrogen production (see Table 2-2 for conversion of glucose to hydrogen equations). 


\subsubsection{Testing Realistic Sparging Rates}

Sparging rates between $1-30 \mathrm{~L} \mathrm{~N} / \mathrm{L}$-hr were tested for the nitrogen sparging rate experiment, but in reality, rates between 0.5 and $2.0 \mathrm{~L}$ gas/L-hr would be more likely obtained for a normal digestion system. Thus, it is recommended that for future research on generating $\mathrm{H}_{2}-\mathrm{CH}_{4}$ mixtures with two-phase digestion, a sparging experiment using the rates above be performed to verify if the ideal sparging rate is actually $1.1 \mathrm{~L}$ gas/L-hr. 


\section{REFERENCES}

Adhikari, S., Fernando, S. D., \& Haryanto, A. (2009). Hydrogen production from glycerol: An update. Energy Conversion and Management, 50(10), 2600-2604. http://doi.org/10.1016/j.enconman.2009.06.011

Alves, H. J., Bley Junior, C., Niklevicz, R. R., Frigo, E. P., Frigo, M. S., \& CoimbraAraújo, C. H. (2013). Overview of hydrogen production technologies from biogas and the applications in fuel cells. International Journal of Hydrogen Energy, 38(13), 5215-5225. http://doi.org/10.1016/j.ijhydene.2013.02.057

APHA. (2005). Standard Methods for the Examination of Water and Wastewater, 21st ed. Washington, D.C.: American Public Health Association.

Bari, S. (1996). Effect of carbon dioxide on the performance of biogas/diesel duel-fuel engine. Renewable Energy, 9(1-4), 1007-1010. http://doi.org/10.1016/09601481(96)88450-3

Bracmort, K. (2010). Anaerobic Digestion: Greenhouse Gas Emission Reduction and Energy Generation. Retrieved from http://nationalaglawcenter.org/wpcontent/uploads/assets/crs/R40667.pdf

CalEPA. (2011). Permit Guidance For Anaerobic Digesters And Co-Digesters. Retrieved from http://www.calepa.ca.gov/Digester/Documents/GuideDigester.pdf

CARB. (2015). Climate Change Programs. Retrieved March 12, 2015, from http://www.arb.ca.gov/cc/cc.htm

CEC. (2015). Anaerobic Digestion. Retrieved April 12, 2015, from http://www.energy.ca.gov/biomass/anaerobic.html

Chang, J. S., Lee, K. S., \& Lin, P. J. (2002). Biohydrogen production with fixed-bed bioreactors. International Journal of Hydrogen Energy, 27(11-12), 1167-1174. http://doi.org/10.1016/S0360-3199(02)00130-1

Choudhuri, A. R., \& Gollahalli, S. R. (2000). Combustion characteristics of hydrogen hydrocarbon hybrid fuels. International Journal of Hydrogen Energy, 25, 451-462. Retrieved from http://www.sciencedirect.com/science/article/pii/S0360319999000270\#

Collier, K., Hoekstra, R. L., Mulligan, N., Jones, C., \& Hahn, D. (1996). Untreated Exhaust Emissions of a Hydrogen-Enriched CNG Production Engine Conversion. Retrieved from http://papers.sae.org/960858/

Cooney, M., Maynard, N., Cannizzaro, C., \& Benemann, J. (2007). Two-phase anaerobic digestion for production of hydrogen - methane mixtures, 98, 26412651. http://doi.org/10.1016/j.biortech.2006.09.054 
Crookes, R. J. (2006). Comparative bio-fuel performance in internal combustion engines. Biomass and Bioenergy, 30(5), 461-468.

http://doi.org/10.1016/j.biombioe.2005.11.022

Das, D., Khanna, N., \& Dasgupta, C. N. (2014). Biohydrogen Production: Fundamentals and Technology Advances. CRC Press. Retrieved from https://books.google.com/books?id=sXvNBQAAQBAJ\&pg=PA240\&lpg=PA240\&dq= reducing+hydrogen+partial+pressure+by+stirring\&source=bl\&ots=y2OHxohsD\&sig=pnrGtSHZ1P5HtLCWyet_8_ce7E\&hl=en\&sa=X\&ei=Sm5LVaWBEsm0ggTkzoCwBg\&ved=0CCIQ6AEwAQ\#v=one page \&q=reducing hydrogen

Demirel, B., \& Yenigün, O. (2002). Two-phase anerobic digestion processes: a review. Journal of Chemical Technology \& Biotechnology, 77(7).

DOE. (2004). DOE Workshop on Hydrogen Production Via Direct Fermentation. Retrieved from https://www1.eere.energy.gov/hydrogenandfuelcells/pdfs/fermentation_wkshp.pdf

DOE. (2013). Anaerobic Digestion Basics. Retrieved March 12, 2015, from http://energy.gov/eere/energybasics/articles/anaerobic-digestion-basics

DOE. (2014). Alternative Fuels Data Center: Hydrogen Production and Distribution. Retrieved January 1, 2015, from http://www.afdc.energy.gov/fuels/hydrogen_production.html

Donkin, S. S., Koser, S. L., White, H. M., Doane, P. H., \& Cecava, M. J. (2009). Feeding value of glycerol as a replacement for corn grain in rations fed to lactating dairy cows. Journal of Dairy Science, 92(10), 5111-5119. http://doi.org/10.3168/jds.20092201

Dürre, P. (2005). Handbook on Clostridia. Boca Raton, FL: CRC Press.

Effendi, a., Hellgardt, K., Zhang, Z. G., \& Yoshida, T. (2005). Optimising H2 production from model biogas via combined steam reforming and $\mathrm{CO}$ shift reactions. Fuel, 84(7-8), 869-874. http://doi.org/10.1016/j.fuel.2004.12.011

ESA. (2011). Economic Feasibility of Dairy Manure Digester and Co-digester Facilities in the Central Valley of California. Retrieved from http://www.waterboards.ca.gov/centralvalley/water_issues/dairies/dairy_program_re gs_requirements/final_dairy_digstr_econ_rpt.pdf

Fang, H. H. P., \& Liu, H. (2002). Effect of $\mathrm{pH}$ on hydrogen production from glucose by a mixed culture. Bioresource Technology, 82(1), 87-93. http://doi.org/10.1016/S09608524(01)00110-9

Fresco, E. (2015). Digestion of Microalgae for Methane Production and Nutrient Recycling. 
FSEC. (2014). Hydrogen Basics - Production. Retrieved January 1, 2015, from http://www.fsec.ucf.edu/en/consumer/hydrogen/basics/production.htm

Gavala, H. N., Skiadas, I. V., \& Ahring, B. K. (2006). Biological hydrogen production in suspended and attached growth anaerobic reactor systems. International Journal of Hydrogen Energy, 31(9), 1164-1175. http://doi.org/10.1016/j.ijhydene.2005.09.009

Ghosh, S., Ombregt, J. P., \& Pipyn, P. (1985). Methane production from industrial wastes by two-phase anaerobic digestion. Water Research, 19(9), 1083-1088. http://doi.org/10.1016/0043-1354(85)90343-4

Hallenbeck, P. C., \& Benemann, J. R. (2002). Biological hydrogen production; Fundamentals and limiting processes. International Journal of Hydrogen Energy, 27(11-12), 1185-1193. http://doi.org/10.1016/S0360-3199(02)00131-3

Hill, A. (2014). Effect of Pretreatment Technologies of Wastewater Grown Microalgae: In Preparation for Anaerobic Digestion.

Holladay, J. D., Hu, J., King, D. L., \& Wang, Y. (2009). An overview of hydrogen production technologies. Catalysis Today, 139(4), 244-260. http://doi.org/10.1016/j.cattod.2008.08.039

Jones, G. M. (2008). Pumping Station Design. (G. Tchobanoglous, B. E. Bosserman, \& R. L. Sanks, Eds.). Retrieved from https://books.google.com/books?id=biWHfrpd9gsC\&pg=SA14-PA6\&lpg=SA14PA6\&dq =catalytic+converters+fouled + by + biogas \&source $=b \mid \& o t s=w N c N k o j B C v \& s i g$ =jty87CPoVPMQVwxYhR_hdGMZNt0\&hl=en\&sa=X\&ved=0ahUKEwi5wLiyj9fJAhUx IIMKHVWYAI4Q6AEIJDAB $\# v=$ onepage \&q=catalytic converters fouled by biogas\&f=false

Karakashev, D., \& Angelidaki, I. (2011). Chapter 23: Thermophilic Biohydrogen Production, of Biofuels: Alternative Feedstocks and Conversion Processes. Elsevier. Retrieved from https://books.google.com/books?id=DnyfnOsTLfcC\&pg=PA526\&lpg=PA526\&dq=st oichiometric+glucose+to+hydrogen $+12+\mathrm{mol} / \mathrm{mol} \&$ source=bl\&ots=TfzbNHATQY\&sig $=$ QPOOeoPtqASXpo-FhM1LAQAYOVg\&hl=en\&sa $=X \& e i=-$ 803VYqDJ8uYgwSt9oHgAw\&ved=0CDMQ6AEwBQ\#v=onepage\&q=stoichiometric gl\&

Kim, S. H., Han, S. K., \& Shin, H. S. (2006). Effect of substrate concentration on hydrogen production and 16S rDNA-based analysis of the microbial community in a continuous fermenter. Process Biochemistry, 41(1), 199-207. http://doi.org/10.1016/j.procbio.2005.06.013

Kornbluth, K., Greenwood, J., Jordan, E., McCaffrey, Z., \& Erickson, P. a. (2012). Economic feasibility of hydrogen enrichment for reducing NOx emissions from landfill gas power generation alternatives: A comparison of the levelized cost of electricity with present strategies. Energy Policy, 41(x), 333-339. http://doi.org/10.1016/j.enpol.2011.10.054 
Krich, K., Augenstein, D., Batmale, J., Benemann, J., Rutledge, B., \& Salour, D. (2005). Biomethane from Dairy Waste: A Sourcebook for the Production and Use of Renewable Natural Gas in California. Retrieved from http://suscon.org/cowpower/biomethaneSourcebook/biomethanesourcebook.php

Liang, K., \& Pirnie, M. (2009). Regulatory Impacts of Biogas-fired Internal Combustion Engines. In CWEA Air, Water, \& Energy Conference: Sustainability for Wastewater Treatment Plants. Retrieved from https://www.cwea.org/sarbs/pdfs/AirWaterEnergyConf/BiogasEngineRegCWEAJun e112009.pdf

Lin, C. Y., Lee, C. Y., Tseng, I. C., \& Shiao, I. Z. (2006). Biohydrogen production from sucrose using base-enriched anaerobic mixed microflora. Process Biochemistry, 41(4), 915-919. http://doi.org/10.1016/j.procbio.2005.10.010

Lin, C.-Y., \& Chang, R.-C. (1999). Hydrogen production during the anaerobic acidogenic conversion of glucose. Journal of Chemical Technology and Biotechnology, 74(6), 498-500. Retrieved from http://onlinelibrary.wiley.com/doi/10.1002/\%28SICl\%2910974660\%28199906\%2974:6\%3C498::AID-JCTB67\%3E3.0.CO;2-D/abstract

Lundquist Laboratory, C. P. (2014). GC Bench Method for Biogas Measurement Using Argon and Helium Carrier Gases. San Luis Obispo.

McCarty, P. L. (1964). Anaerobic Waste Treatment Fundamentals. Public Works, 95(9,10,11,12). Retrieved from http://www.seas.ucla.edu/stenstro/Anaerobic assignment.pdf

Metcalf \& Eddy. (2013). Wastewater Engineering Treatment and Reuse. New York, NY: McGraw-Hill.

Mizuno, O., Dinsdale, R., Hawkes, F. R., Hawkes, D. L., \& Noike, T. (2000). Enhancement of hydrogen production from glucose by nitrogen gas sparging. Bioresource Technology, 73(1), 59-65. http://doi.org/10.1016/S09608524(99)00130-3

Mohan, S. V. (2009). Waste to Renewable Energy. In O. V. Singh \& S. P. Harvey (Eds.), Sustainable Biotechnology: Sources of Renewable Energy. http://doi.org/10.1007/978-90-481-3295-9

Pettygrove, G. S., Putnam, D. H., \& Meyer, D. M. (2003). Integrating Forage Production with Dairy Manure Management in the San Joaquin Valley.

Qorpak. (2015). Flourination: The Solution to Plastic Bottle Paneling. Retrieved July 12, 2015, from http://www.qorpak.com/pages/Fluorination

R-Biopharm. (2015). UV-method for the Determination of D-glucose in Foodstuffs and Other Materials. Retrieved from http://www.r-biopharm.com/wpcontent/uploads/4050/Glucose_EN_10716251035_2013-03.pdf 
Ruggeri, B., Tommasi, T., \& Sanfilippo, S. (2015). BioH2 \& BioCH4 Through Anaerobic Digestion: From Research to Full-scale Applications. Springer-Verlag London. http://doi.org/10.1007/978-1-4471-6431-9

Shrestha, S. O. B., \& Karim, G. . (1999). Hydrogen as an additive to methane for spark ignition engine applications. International Journal of Hydrogen Energy, 24(6), 577586. http://doi.org/10.1016/S0360-3199(98)00103-7

Sierens, R. (1998). Variable Composition Hydrogen/Natural Gas Mixtures for Increased Enginge Efficiency and Decreased Emissions. Retrieved from http://www.althytude.info/fileadmin/user_upload/documents/SierensH2NG_mixtures.pdf

Spierling, R. E., Albinger, L. C., \& Lundquist, T. J. (2009). Projected Performance and Costs of Wastewater Treatment at California Flush Dairies. San Luis Obispo.

Sreethawong, T., Niyamapa, T., Neramitsuk, H., Rangsunvigit, P., Leethochawalit, M., \& Chavadej, S. (2010). Hydrogen production from glucose-containing wastewater using an anaerobic sequencing batch reactor: Effects of COD loading rate, nitrogen content, and organic acid composition. Chemical Engineering Journal, 160(1), 322332. http://doi.org/10.1016/j.cej.2010.03.037

Sung, S., Raskin, L., Duangmanee, T., Padmasiri, S. I., \& Simmons, J. J. (2007). Hydrogen Production by Anaerobic Microbial Communities Exposed to Repeated Heat Treatments. Water Environment Research : A Research Publication of the Water Environment Federation, 79(9), 975-83. Retrieved from http://www1.eere.energy.gov/hydrogenandfuelcells/pdfs/32405a13.pdf

TerMaath, C. Y., Skolnik, E. G., Schefer, R. W., \& Keller, J. O. (2006). Emissions reduction benefits from hydrogen addition to midsize gas turbine feedstocks. International Journal of Hydrogen Energy, 31(9), 1147-1158. http://doi.org/10.1016/j.ijhydene.2005.10.002

The White House. (2014). Climate Action Plan: Strategy to Reduce Methane Emissions. Washington D.C. Retrieved from https://www.whitehouse.gov/sites/default/files/strategy_to_reduce_methane_emissi ons_2014-03-28_final.pdf

USDA. (2009). Cooperative Approaches for Implementation of Dairy Manure Digesters. Environmental Protection. Retrieved from http://www.rd.usda.gov/files/rr217.pdf

USEPA. (2010). California Dairy Digester Workshop. Retrieved May 5, 2015, from http://www.epa.gov/agstar/news-events/events/workshop10.html

USEPA. (2013). Region 9 Strategic Plan, 2011-14. Geographic Area of Focus: San Joaquin Valley. Retrieved January 1, 2015, from http://www.epa.gov/region9/strategicplan/sanjoaquin.html 
USEPA. (2014a). Climate Change Indicators in the United States: Greenhouse Gases. Retrieved January 5, 2015, from http://www.epa.gov/climate/climatechange/science/indicators/ghg/index.html

USEPA. (2014b). Inventory of U.S. Greenhouse Gas Emissions and Sinks: 1990 - 2012. Washington, DC. Retrieved from http://www.epa.gov/climatechange/ghgemissions/usinventoryreport.html

USEPA. (2015). Comprehensive Livestock Digester Database. Retrieved from http://www.epa.gov/agstar/downloads/digesters_all_20150129.xlsx

Valdez-Vazquez, I., \& Poggi-Varaldo, H. M. (2009). Hydrogen production by fermentative consortia. Renewable and Sustainable Energy Reviews, 13(5), 10001013. http://doi.org/10.1016/j.rser.2008.03.003

Wang, G., Mu, Y., \& Yu, H.-Q. (2005). Response surface analysis to evaluate the influence of $\mathrm{pH}$, temperature and substrate concentration on the acidogenesis of sucrose-rich wastewater. Biochemical Engineering Journal, 23(2), 175-184. http://doi.org/10.1016/j.bej.2005.01.002

Wang, J., \& Wan, W. (2009). Factors influencing fermentative hydrogen production: A review. International Journal of Hydrogen Energy, 34(2), 799-811. http://doi.org/10.1016/j.ijhydene.2008.11.015

Westermann, P., \& Ahring, B. (2006). Biofuels for Fuel Cells (Integrated Environmental Technology). (P. Lens, P. Westermann, \& A. Haberbauer, Eds.). IWA Publishing.

Wilkie, A. (2000). Fixed Film Anaerobic Digester. Retrieved from http://www.epa.gov/agstar/documents/Fixed_Film_Anaerobic_Digester.pdf

Wilson, R. P. (2012). Application of Hydrogen Assited Lean Operation to Biogas Fueled Reciprocating Engines (BioHALO). Retrieved from http://www.energy.ca.gov/2012publications/CEC-500-2012-064/CEC-500-2012064.pdf

WtERT. (2009). Anaerobic Digestion Process. Retrieved from http://www.wtert.eu/default.asp?Menue=13\&ShowDok=12

Yu, Z., \& Schanbacher, F. L. (2009). Production of Methane Biogas as Fuel Through Anaerobic Digestion. In O. V. Singh \& S. P. Harvey (Eds.), Sustainable Biotechnology: Sources of Renewable Energy (pp. 107-108). Retrieved from https://books.google.com/books?id=TbMWusKqTc8C\&pg=PA145\&lpg=PA145\&dq= $2+\mathrm{mol}+\mathrm{H} 2 / \mathrm{mol}+$ glucose + practical+limit\&source=bl\&ots=56JYDbTP_\&sig=N8LQDOCvlU89iC_bND11jcXGzU4\&hl=en\&sa=X\&ei=qNM3VbbvKcK5g gTT4YKgAw\&ved=0CCsQ6AEwAg\#v=onepage \&q=complex community\&f=false

Zhang, Z.-P., Show, K.-Y., Tay, J.-H., Liang, D. T., Lee, D.-J., \& Jiang, W.-J. (2006). Effect of hydraulic retention time on biohydrogen production and anaerobic microbial community. Process Biochemistry, 41(10), 2118-2123. http://doi.org/10.1016/j.procbio.2006.05.021 


\section{APPENDICES}

\section{Appendix A - Second-Phase Gas Production Rate Calculations}

Goal: Calculate the theoretical biogas production rate of the second-phase and compare it to the actual biogas production rate (estimated as the sparging rate) to determine if the second-phase digesters were operating normally.

Known Data: The list below and Table-A1 display relevant data for this calculation:

- Average Feed COD ( $1^{\text {st }}$-phase effluent $)=C O D_{1 N}=10427.4 \mathrm{mg} / \mathrm{L}$

- Average Effluent COD $=\mathrm{COD}_{\mathrm{EFF}}=1218.7 \mathrm{mg} / \mathrm{L}$

- Volume of One Second-phase Digester $=\mathrm{V}_{\text {digester }}=20 \mathrm{~L} /$ digester

- Total \# of Second-phase Digesters = 2

- $\mathrm{HRT}=30$ days

- Temperature $=\mathrm{T}=30^{\circ} \mathrm{C}$

Table A-1: Gas composition, gas flow, and volumetric $\mathrm{H}_{2}$ yield for all digesters operated in the integrated experiment.

\begin{tabular}{cccccc}
\hline Digester & \multicolumn{3}{c}{ Avg. Gas Composition } & $\begin{array}{c}\text { Total Gas } \\
\text { Flow (L/day) }\end{array}$ & $\begin{array}{c}\text { Volumetric } \mathrm{H}_{2} \\
\text { Yield (L/day) }\end{array}$ \\
\cline { 2 - 4 }$\% \mathrm{H}_{2}$ & $\% \mathrm{CO}_{2}$ & $\% \mathrm{CH}_{4}$ & & \\
\hline $\begin{array}{c}\text { Sparged First-phase } \\
\text { Digester }\end{array}$ & 25.5 & 54.5 & 20.0 & $9.12^{1}$ & 2.19 \\
$\begin{array}{c}\text { Non-Sparged First-phase } \\
\text { Digester (Control) }\end{array}$ & 52.7 & 47.3 & 0.0 & $2.46^{1}$ & 1.16 \\
$\begin{array}{c}\text { Second-phase Digesters } \\
\text { (Combined) }\end{array}$ & 0.0 & 38.1 & 61.9 & $6.66^{2}$ & $\begin{array}{c}\text { Does Not } \\
\text { Apply }\end{array}$ \\
\hline
\end{tabular}

${ }^{1}$ The average gas flow measured by the gas meters during steady-state.

${ }^{2}$ Gas meters could not be used to directly measure the second-phase production rate. Instead, this value was estimated by subtracting the non-sparged first-phase digester flow rate from the sparged first-phase digester flow rate. This value is approximately equal to $0.28 \mathrm{~L}$ gas $/ \mathrm{L}-\mathrm{hr}$ sparging rate.

${ }^{3}$ The average of all volumetric $\mathrm{H}_{2}$ yields calculated for each day at steady state (from Excel spreadsheets). This column may not match the (total gas flow * $\% \mathrm{H}_{2}$ ).

\section{Solution:}

Step 1.) Use $C O D$ mass balance to calculate $\mathrm{CH}_{4}$-equivelant $\mathrm{COD}(\mathrm{CODCH})_{4}$

$$
\begin{gathered}
\mathrm{COD}_{\mathrm{IN}}=\mathrm{COD}_{\mathrm{EFF}}+\mathrm{COD}_{\mathrm{CH}_{4}} \\
\frac{10427.4 \mathrm{mg}}{\mathrm{L}}=\frac{1218.7 \mathrm{mg}}{\mathrm{L}}+\mathrm{COD}_{\mathrm{CH}_{4}}
\end{gathered}
$$




$$
\operatorname{COD}_{\mathrm{CH}_{4}}=\frac{9208.7 \mathrm{mg}}{\mathrm{L}}
$$

Step 2.) Convert $C O D_{C H 4}$ into theoretical volume of $\mathrm{CH}_{4}$ gas (at $1 \mathrm{~atm}, \mathrm{~T}=30^{\circ} \mathrm{C}$ ) produced per day, per digester (a.k.a. $\mathrm{CH}_{4}$ production rate)

$$
\begin{gathered}
\text { Theoretical } \mathrm{CH}_{4} \text { Production Rate }= \\
\frac{\mathrm{V}_{\text {digester }}(\mathrm{L} / \text { digester })}{\mathrm{HRT}(\text { day })}\left(\mathrm{COD}_{\mathrm{CH}_{4}}\left(\frac{\mathrm{mg} \mathrm{COD}}{\mathrm{L}}\right)\right)\left(\frac{1 \mathrm{~g}}{1000 \mathrm{mg}}\right)\left(\frac{0.39 \mathrm{~L} \mathrm{CH}_{4}}{\mathrm{~g} \mathrm{COD}}\right) \\
\text { Theoretical } \mathrm{CH}_{4} \text { Production Rate }=\frac{20 \mathrm{~L} / \text { digester }}{30 \text { day }}\left(\frac{9208.7 \mathrm{mg} \mathrm{COD}}{\mathrm{L}}\right)\left(\frac{1 \mathrm{~g}}{1000 \mathrm{mg}}\right)\left(\frac{0.39 \mathrm{~L} \mathrm{CH}_{4}}{\mathrm{~g} \mathrm{COD}}\right) \\
\text { Theoretical } \mathbf{C H}_{\mathbf{4}} \text { Production Rate }=\frac{\mathbf{2 . 4} \mathbf{~ L ~ C H}}{\mathbf{d a y} \mathbf{- ~ d i g e s t e r}}
\end{gathered}
$$

Step 3.) Calculate the total, combined gas production rate for both digesters assuming $61.9 \% \mathrm{CH}_{4}, 38.1 \% \mathrm{CO}_{2}$ in the biogas (from Table A-1)

$$
\begin{aligned}
& \text { Theoretical Gas Production Rate }=\left(\mathrm{CH}_{4} \text { Production Rate }\right) \times(2 \text { digesters }) \times\left(\frac{100 \mathrm{~L} \mathrm{Biogas}}{61.9 \mathrm{LCH}_{4}}\right) \\
& \text { Theoretical Gas Production Rate }=\left(\frac{2.4 \mathrm{LCH}_{4}}{\text { day }- \text { digester }}\right) \times(2 \text { digesters }) \times\left(\frac{100 \mathrm{LBiogas}}{61.9 \mathrm{LCH}_{4}}\right) \\
& \text { Theoretical Gas Production Rate }=\frac{7.75 \text { L Biogas }}{\text { day }}\left(\text { same as } \frac{0.32 \text { L Biogas }}{h r}\right)
\end{aligned}
$$

Step 4.) Calculate percent error between theoretical and actual gas production from the second-phase (Note: actual gas production was estimated by assuming the sparging rate was nearly the same value $(6.66 \mathrm{~L}$ /day or $0.28 \mathrm{~L} / \mathrm{hr})$ )

$$
\% \text { Error }=\frac{(\text { Theoretical Biogas Production Rate })-(\text { Actual Biogas Production Rate })}{(\text { Theoretical Biogas Production Rate })} \times 100
$$

$$
\% \text { Error }=\frac{7.75-6.66}{7.75} \times 100 \%=14.1 \%
$$

